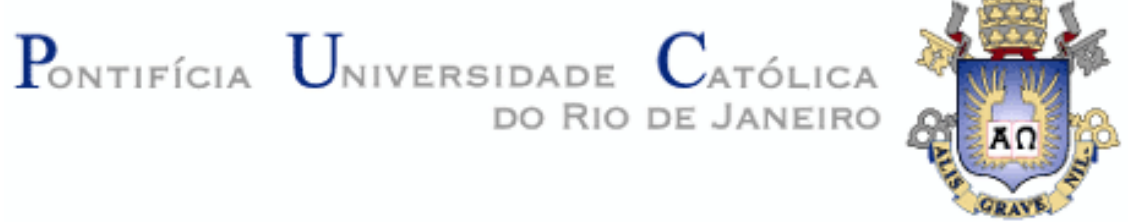

Juliana Provenzano Jou Alves

\title{
Modelagem e Simulação dos terminais de granéis agrícolas no Porto de Santos
}

Dissertação de Mestrado

Dissertação apresentada como requisito parcial para obtenção do grau de Mestre pelo Programa de Pós-Graduação em Engenharia de Produção do Departamento de Engenharia Industrial da PUCRio.

Orientador: Prof. Jose Eugênio Leal Co-orientador: Alexandre Magno Castañon Guimarães

Rio de Janeiro

Outubro de 2012 


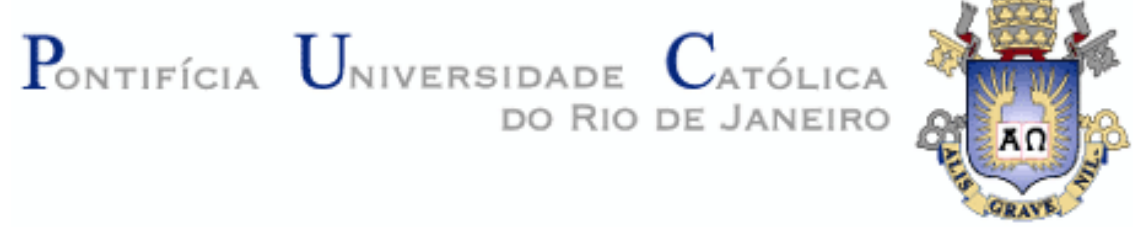

Juliana Provenzano Jou Alves

\title{
Modelagem e Simulação dos terminais de granéis agrícolas no Porto de Santos
}

Dissertação apresentada como requisito parcial para obtenção do grau de Mestre pelo Programa de Pós-Graduação em Engenharia de Produção PUC-Rio. Aprovada pela Comissão Examinadora abaixo assinada.

\author{
Prof. José Eugênio Leal \\ Orientador \\ Departamento de Engenharia Industrial - PUC-Rio \\ Prof. Alexandre Magno Castañon Guimarães \\ Co-orientador \\ Teadit Industria e Comércio LTDA
}

Prof. Nélio Domingues Pizzolato

Departamento de Engenharia Industrial - PUC-Rio

Profa. Vânia Barcellos Gouvêa Campos

Departamento de Engenharia de Transporte - IME

Prof. José Eugênio Leal

Coordenador Setorial do Centro Técnico Científico - PUC-Rio

Rio de Janeiro, 01 de outubro de 2012 
Todos os direitos reservados. É proibida a reprodução total ou parcial do trabalho sem autorização da universidade, do autor e do orientador.

\section{Juliana Provenzano Jou Alves}

Graduou-se em Engenharia de Produção pela Pontifícia Universidade Católica do Rio de Janeiro.

Ficha Catalográfica

\footnotetext{
Alves, Juliana Provenzano Jou

Modelagem e simulação dos terminais de granéis agrícolas no Porto de Santos / Juliana Provenzano Jou Alves ; orientador: José Eugenio Leal ; co-orientador: Alexandre Magno Castañon Guimarães. - 2012.

108 f. : il. (color.) ; $30 \mathrm{~cm}$

Dissertação (mestrado)-Pontifícia Universidade Católica do Rio de Janeiro, Departamento de Engenharia Industrial, 2012.

Inclui bibliografia
}

1. Engenharia Industrial - Teses. 2. Modelagem. 3. Simulação. 4. Soja. I. Leal, José Eugenio. II. Guimarães, Alexandre Magno Castañon. III. Pontifícia Universidade Católica do Rio de Janeiro. Departamento de Engenharia Industrial. IV. Título.

CDD: 658.5 
À minha avó Lygia Maria Jou, in memoriam, por sempre acreditar que eu poderia ir além. 


\section{Agradecimentos}

Aos meus pais que sempre me incentivaram ao longo da minha vida e meus irmãos pela paciência e companheirismo.

Ao meu orientador Professor José Eugênio Leal pela parceria para a realização deste trabalho.

Ao Alexandre Magno Castañon Guimarães pela ajuda ímpar para a realização deste trabalho.

Ao CNPq e à PUC-Rio, pelos auxílios concedidos, sem os quais este trabalho não poderia ter sido realizado.

Aos professores que participaram da Comissão examinadora.

Aos professores e amigos do mestrado pela ajuda e troca de experiências, em especial: Bárbara, David, Frank, Lívia, Nayara e Nádia.

A todos aqueles que de uma maneira direta ou indireta me ajudaram. 


\section{Resumo}

Alves, Juliana Provenzano Jou; Leal, José Eugenio. Modelagem e Simulação dos terminais de granéis agrícolas no Porto de Santos. Rio de Janeiro, 2012. 108 p. Dissertação de Mestrado - Departamento de Engenharia Industrial, Pontifícia Universidade Católica do Rio de Janeiro.

O Brasil é o segundo maior produtor de soja, sendo a principal cultura explorada no mercado interno. Para a exportação da soja brasileira, se observam gargalos logísticos no modal rodoviário, que possui maior representatividade na matriz de transporte do país, e na baixa participação dos modais ferroviário e hidroviário. A falta de infraestrutura nos portos brasileiros e a falta de terminais para integração entre os modais são um agravante para a integração logística. Com a movimentação das cargas, os portos assumem função estratégica na cadeia passando a ser elo fundamental no canal de comercialização. O Porto de Santos é a principal via de entrada e saída de mercadorias do país e enfrenta muitos problemas em sua infraestrutura. Neste contexto se torna cada vez mais importante à definição e implantação de projetos de melhorias nos portos brasileiros para que os produtos nacionais adquiram competitividade no mercado internacional. Esse trabalho tem como objetivo analisar a movimentação da soja no Porto de Santos, através da técnica de Modelagem e Simulação, utilizando software especializado. Para tanto, foi necessário saber a extensão do problema e de todas as peculiaridades que envolvem o sistema logístico da Baixada Santista. A partir desse ponto, foi possível a construção e validação do modelo. Com o modelo validado, foram testados cenários, e dentre os cenários simulados, alguns se destacam como possíveis para a melhoria da movimentação e exportação da soja brasileira.

\section{Palavras-chave}

Modelagem; Simulação; Soja. 


\section{Abstract}

Alves, Juliana Provenzano Jou; Leal, José Eugenio (Advisor). Modeling and Simulation of bulk terminals used for export at Santos port. Rio de Janeiro, 2012. 108 p. MSc. Dissertation - Departamento de Engenharia Industrial, Pontifícia Universidade Católica do Rio de Janeiro.

Brazil is the second largest producer of soybeans, the main crop being exploited in the domestic market. For the export of Brazilian soybeans, it is important to emphasize that logistics bottlenecks in the roads, which have the largest representation in the transport matrix of the country, and the low market share of rails and waterways. The lack of infrastructure in Brazilian ports and terminals for integration between the modes is an aggravating factor for logistics integration. Ports have an strategic role in the chain representing a fundamental link in the marketing channel. The Port of Santos is the main route of entry and exit of goods from the country and faces many problems in their infrastructure. In this context becomes increasingly important the definition and implementation of improvement projects in Brazilian ports to allow national products be competitive in the international market. This work aims to analyze the handling of soybeans in the Port of Santos, through the technique of Modeling and Simulation, using specialized software. Therefore, it was necessary to build a solid base of information about the extension of the problem and the Baixada Santista logistic system characteristic. From this point, it was possible to develop and validate the model. With the validated model, scenarios were tested, and among the simulated scenarios, some stand out as possible to improve the handling and export of Brazilian soybeans.

\section{Keywords}

Modeling; Simulation; Soy. 


\section{Sumário}

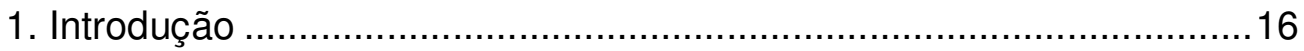

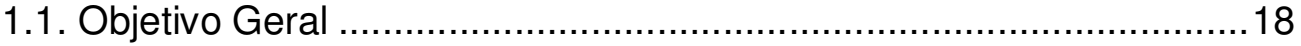

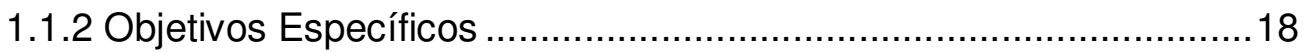

1.2. Estrutura do Trabalho .............................................................. 19

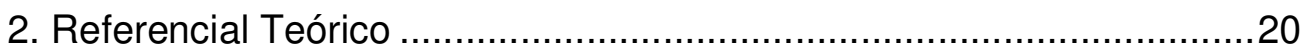

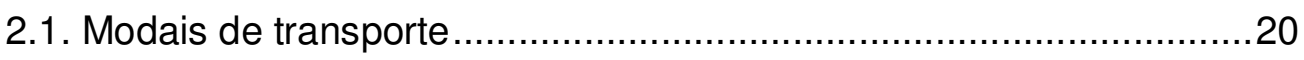

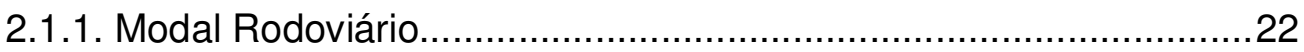

2.1.2. Modal Ferroviário......................................................................24

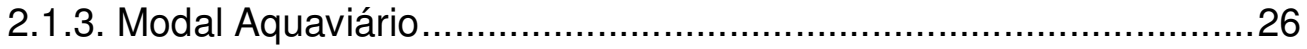

2.2. O mercado da soja .......................................................................

2.2.1. Cadeia produtiva da soja no Brasil ..............................................32

2.2.2. Produção e consumo da soja no Brasil ..........................................34

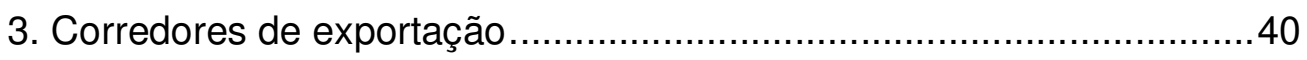

3.1. A integração logística no escoamento da soja ................................. 40

3.2. Principais corredores de escoamento ........................................... 41

3.2.1. O escoamento da soja................................................................. 43

4. Análise dos portos para atender o comércio exterior ...........................47

4.1. Evolução da demanda por serviços nos portos .................................49

4.2. A demanda das regiões por serviços portuários ...............................53

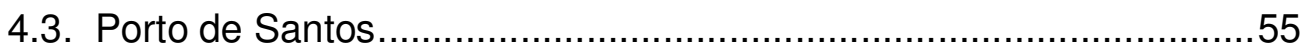

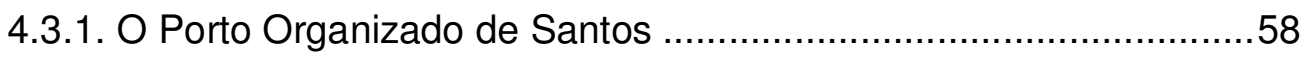

4.3.2. Evolução da movimentação das cargas do agronegócio no

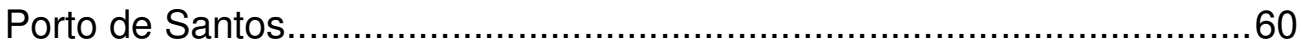

4.3.3. Acessos Ferroviários ao Porto de Santos ………………….........66

4.3.4. Acessos Rodoviários ao Porto de Santos .....................................68

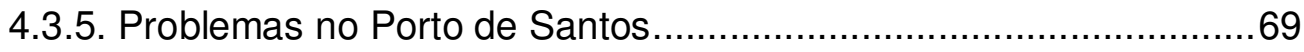


4.3.6. Investimentos

5. Modelagem e simulação de sistemas..................................................

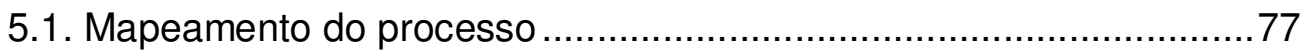

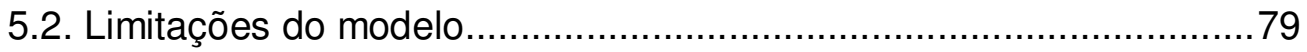

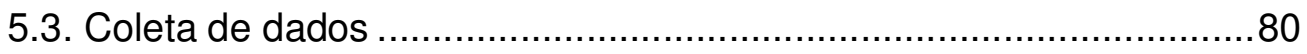

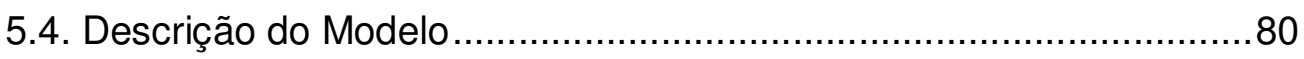

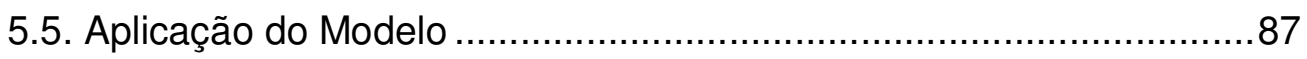

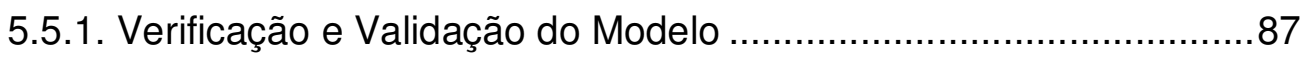

5.5.2. Tamanho das replicações e número de replicações .......................87

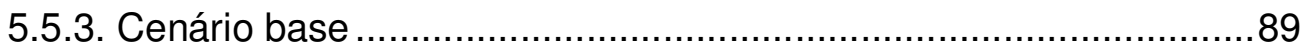

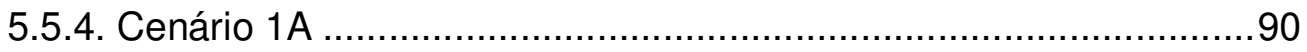

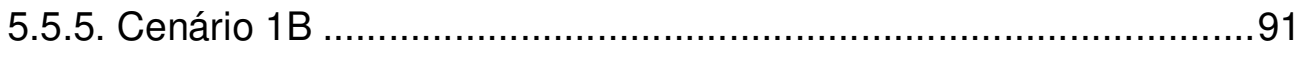

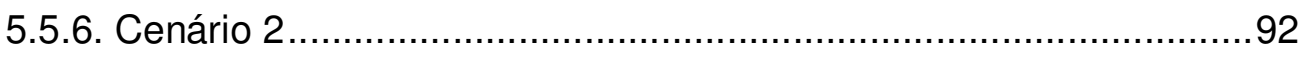

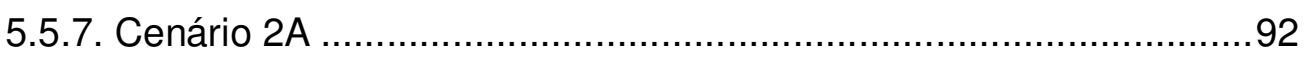

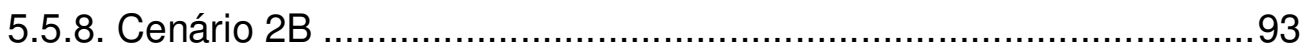

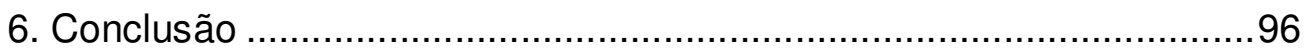

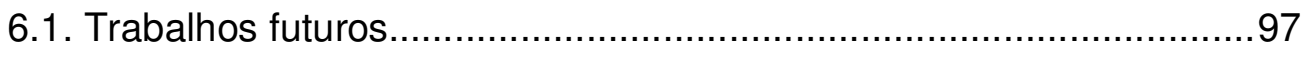

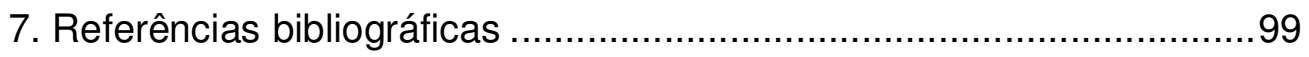

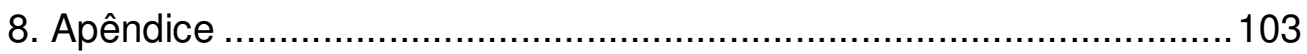

8.1. Codificação do modelo no Arena ...............................................103 


\section{Lista de Tabelas}

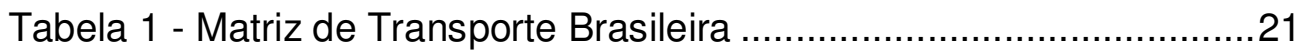

Tabela 2 - Capacidade instalada de processamento da soja no Brasil...34

Tabela 3 - Soja: Comparativo de Área, Produtividade e Produção. ..........35

Tabela 4 - Complexo Soja: Exportações Brasileiras ................................38

Tabela 5 - Principais Tendências da Produção 2011/12 a 2021/22 .........38

Tabela 6 - Principais corredores de escoamento e exportação de soja ...43

Tabela 7 - Movimentação Portuária por Natureza e Região.......................52

Tabela 8 - Exportações dos estados produtores de soja, em toneladas ..54

Tabela 9 - Exportações dos estados produtores de soja, em valor ...........54

Tabela 10 - Resumo das exportações de cargas no porto de Santos......63

Tabela 11 - Resumo das importações e movimentações de

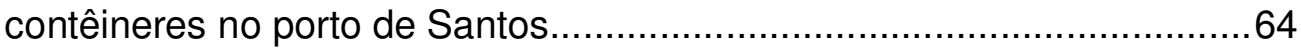

Tabela 12 - Movimentação de contêineres. 2007 - 2011 ..........................65

Tabela 13 - Toneladas médias movimentadas por navio e navegação....65

Tabela 14 - Evolução do Comércio Exterior Brasileiro - 2002 a 2011......65

Tabela 15 - Chegada de navios para embarque - Comparativo de

Distribuições.

Tabela 16 - Chegada de navios para embarque - Distribuição ajustada. 82

Tabela 17 - Chegada de navios para embarque - Teste Kolmogorov-

Smirnov .82

Tabela 18 - Tempo médio de espera para atracação

Tabela 19 - Tempo médio de espera para atracação - Distribuição

ajustada.

Tabela 20 - Tempo médio de espera para atracação - Teste

Kolmogorov-Smirnov.

Tabela 21 - Tempo médio de operações de carga e descarga .................85

Tabela 22 - Tempo médio de operação - Distribuição ajustada. ...............86

Tabela 23 - Tempo médio de operação - Teste Kolmogorov-Smirnov.....86

Tabela 24 - Cenário base: resultados.

Tabela 25 - Cenário base: Total de carga movimentada por berços.......89

Tabela 26 - Cenário 1A: resultados. 
Tabela 27 - Cenário 1A: Total de carga movimentada por berços. .........90

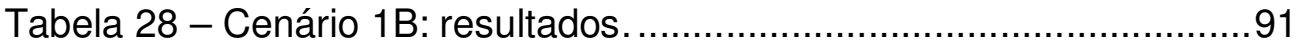

Tabela 29 - Cenário 1B: Total de carga movimentada por berços. ..........91

Tabela 30 - Cenário 2A: resultados................................................93

Tabela 31 - Cenário 2A: Total de carga movimentada por berços. .........93

Tabela 32 - Cenário 2B: resultados..................................................94

Tabela 33 - Cenário 2B: Total de carga movimentada por berços. .........94 


\section{Lista de Gráficos}

Gráfico 1 - Movimentação de Cargas nos Portos Públicos e TUP ...........50

Gráfico 2 - Principais participações dos portos - 2011........................66

Gráfico 3 - Histograma da chegada de navios ao porto. ......................... 83

Gráfico 4 - Histograma do tempo médio de espera para atracação dos navios.................................................................................. 84

Gráfico 5 - Histograma do tempo médio de operação de embarque de

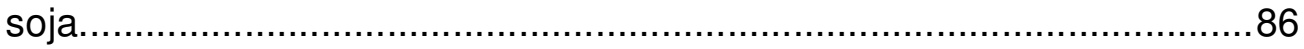




\section{Lista de Figuras}

Figura 1 - Classificação Geral por Região Geográfica. ...........................23

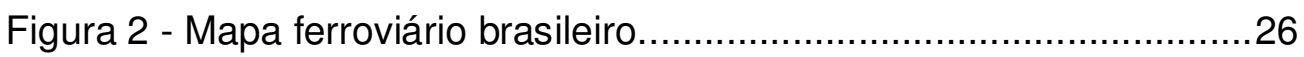

Figura 3 - Exportação de soja dos Estados Unidos por modal.................27

Figura 4 - Intermodalidade Brasil x EUA. ............................................28

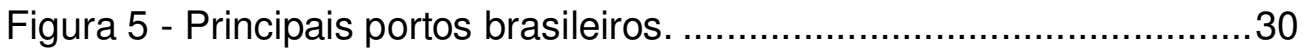

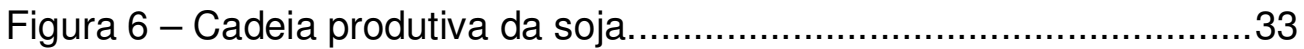

Figura 7 - Produção da soja em grãos no Brasil: participação das

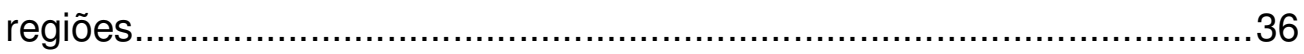

Figura 8 - Produção, exportação e consumo de Soja. .............................37

Figura 9 - Principais Fluxos de Exportação da Soja Brasileira..................44

Figura 10 - Etapas de Evolução dos Portos........................................... 48

Figura 11 - Estados produtores de soja em grãos e suas participações. . 53

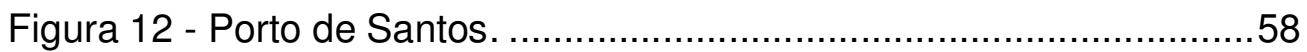

Figura 13 - Malha Ferroviária do Porto de Santos..................................67

Figura 14 - Principais Rodovias no Estado de São Paulo. ........................68

Figura 15 - Etapas do Processo de Simulação. ……………………....... 75

Figura 16 - Fluxograma do processo de embarque de soja no Porto de

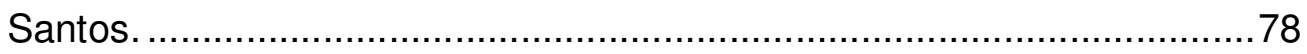

Figura 17 - Chegada de navios de soja, espera para o canal de acesso e escolha do berço (pickstation)..........................................................103

Figura 18 - Berços de atracação dos navios e processo de

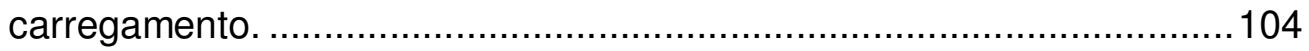

Figura 19 - Entrada no canal de acesso para a volta e saído do porto. .105 Figura 20 - Berços de atracação dos navios e processo de carregamento $(1 \mathrm{~A})$.

Figura 21 - Berços de atracação dos navios e processo de carregamento (1B) - parte 1.

Figura 22 - Berços de atracação dos navios e processo de carregamento (1B) - parte 2 . 108 


\section{Siglas}

ABIOVE - Associação Brasileira da Indústria de Óleos Vegetais

ABTP - Associação Brasileira de Terminais Portuários

ANUT - Associação Nacional dos Usuários do Transporte de Carga

BID - Banco Interamericano de Desenvolvimento

CNT - Confederação Nacional do Transporte

CONAB - Companhia Nacional de Abastecimento

DEPLA - Departamento de Planejamento e Desenvolvimento do Comércio Exterior

DNIT - Departamento Nacional de Infraestrutura de Transportes

EMBRAPA - Empresa Brasileira de Pesquisa Agropecuária

FAPRI - Food and Agricultural Policy Research Institute

IBGE - Instituto Brasileiro de Geografia e Estatística

ILOS - Instituto de Logística e Supply Chain

LSPA - Levantamento Sistemático da Produção Agrícola

MAPA - Ministério da Agricultura, Pecuária e Abastecimento

MDIC - Ministério do Desenvolvimento, Indústria e Comércio Exterior

SECEX - Secretaria de Comércio Exterior

SEP - Secretaria Especial de Portos

USDA - United States Department of Agriculture 
"No meio da dificuldade encontra-se a oportunidade."

Albert Einstein 


\section{Introdução}

A produção agrícola brasileira está presente em regiões no interior do país, se distanciando cada vez mais dos mercados consumidores e dos portos para sua exportação. Por este motivo, o transporte tem se tornado um fator de destaque para a redução dos custos nos produtos nacionais. O Brasil passa por diversos desafios por consequência da falta de investimentos em infraestrutura. Como resultado, gargalos logísticos são gerados na cadeia de produção, no transporte e na distribuição dos grãos desde o produtor até o seu destino final. Para reverter este quadro, são necessários investimentos em tecnologia e infraestrutura, principalmente em hidrovias, portos, armazéns, para conseguir atender a demanda por serviços de transporte de granéis sólidos agrícolas, tanto no longo curso e cabotagem, quanto na navegação interior.

O complexo soja representa grande potencial para as relações de comércio que o Brasil mantêm com o exterior e como base para o desenvolvimento industrial e econômico para diversas regiões do país. De acordo com a CONAB (2012), a produção brasileira de soja está estimada em 66,3 milhões de toneladas para a safra de $2011 / 2012$. Este volume é $-11,9 \%$ ou 8,94 milhões de toneladas inferiores à produção obtida na safra 2010/2011, quando foram colhidas 75,3 milhões de toneladas. Segundo MAPA (2012), a estimativa para a produção da soja em grão para a safra de 2021/2022 seria de 88,9 milhões de toneladas, com taxa de crescimento anual prevista para a produção de $2,3 \%$ no período da projeção, 2011/2012 a 2021/2022. Atualmente, a produção de soja se depara com incertezas referentes ao processo de escoamento da produção de grãos, concentradas, principalmente, na reduzida capacidade de armazenagem, e no baixo investimento nos portos brasileiros.

Os portos são fundamentais ao Brasil dada a importância do transporte marítimo para o comércio internacional. Porém, após muitos anos sem investimentos financeiros, os portos brasileiros estão passando por um processo de readequação, tanto com relação ao exigente mercado internacional, como em relação às suas formas administrativas e de infraestrutura portuária. A operação portuária é uma atividade extremamente complexa, que exige integração logística e abrange diversos serviços desde a chegada do navio no porto, seu atracamento, o 
transbordo de cargas e saída do navio para um novo destino, com reflexos diretos e indiretos na economia dos municípios.

O porto de Santos é um dos maiores portos brasileiros e administrado pela Companhia de Docas do Estado de São Paulo (CODESP). No ano de 2011, o movimento de cargas ultrapassou 97 milhões de toneladas e, de acordo com a CODESP (2012), o porto possui o desafio e meta de em 2025 alcançar 230 milhões de toneladas por ano. Atualmente, o porto passa por problemas logísticos que se mostram cada vez mais urgentes, sendo os principais os grandes congestionamentos no acesso terrestre e marítimo, falta de equipamentos modernos e pouca disponibilidade de armazenagem.

Pelo fato do complexo soja representar o produto com maior potencial para alavancagem no comércio exterior, este trabalho apresenta uma caracterização dos principais produtos do complexo soja brasileiro, com o objetivo de realizar uma análise de evolução da sua competitividade diante dos principais produtores e consumidores mundiais. De acordo com Caixeta-Filho e Martins (2010), no Brasil, assim como Estados Unidos e Europa, a escolha do modal de transporte está associada aos serviços logísticos que são demandados pela competitividade de uma economia globalizada. É possível verificar a grande diferença nos custos de transporte brasileiro, sendo os problemas estruturais os principais responsáveis pelo alto custo do transporte no Brasil. Segundo Ojima (2004), pelo fato de a infraestrutura dos modais ferroviário e aquaviário serem deficientes e não suficientes para realizar o transporte da soja, é necessária a participação do modal rodoviário em grande parte da produção de soja brasileira, mesmo para longas distâncias. Hoje, $60 \%$ da soja é movimentada pelas rodovias brasileiras, onerando, consideravelmente, o preço do transporte do granel.

Destaca-se ainda, no presente estudo, outro problema enfrentado pelos agricultores nacionais e que diz respeito às modificações climáticas que trazem irregularidades na produção no período de chuvas. Um dos maiores desafios da cadeia de produção da soja, além de elaborar estratégias comerciais, é o de administrar a sazonalidade, característica predominante na maioria dos produtos agrícolas. Essa situação ocorre geralmente entre os meses de março a maio e, em alguns anos, se estende até os meses de junho ou julho. Nesse período, a pressão da demanda de soja em grão e farelo por transporte até os portos faz com que haja uma elevação nos fretes rodoviários, permitindo que as empresas ferroviárias e 
hidroviárias também aumentem seus preços. A ocorrência de chuvas acarreta perdas na safra agrícola e atrasos nas colheitas. Em certas regiões, a chuva provoca congestionamentos tanto nas rodovias como nos portos brasileiros. Em terra, é possível verificar enormes filas de caminhões para entrar no porto, ocasionando atraso nos embarques tanto de soja quanto de outros produtos. Este é um problema que afeta toda a cadeia logística, além da competitividade do grão brasileiro.

A primeira parte do trabalho tem como objetivo apresentar um diagnóstico do transporte de granéis sólidos no Brasil, em particular de granéis agrícolas, com ênfase no atual mercado brasileiro de soja, considerando os aspectos técnicos, econômicos e regulatórios e as perspectivas desse mercado. Diante disso, é possível identificar os problemas enfrentados com relação ao transporte da soja para a exportação pelo Porto de Santos.

Para a segunda frente do trabalho aplicou-se a técnica de Simulação, através do software Arena, ao Porto de Santos, com a finalidade de avaliar sua operacionalidade nos anos de jan/2010 a jun/2012. A técnica foi aplicada ao Corredor de Exportação do Porto de Santos, e as análises foram realizadas considerando os processos de chegada e de operação do cais público do porto santista, como um sistema global. A simulação também foi aplicada visando estimar a operacionalidade, em termos de congestionamento, operando com mais berços de atracação e o impacto da ocorrência de chuvas.

\subsection{Objetivo Geral}

Apresentar o mercado brasileiro da soja e a infraestrutura logística do País, através de revisão bibliográfica acerca do assunto. Em segundo momento, o trabalho tem como objetivo fazer uma análise da operação do Porto de Santos, em termos de congestionamento, através do estudo dos dados de movimentação e operação de navios, usando a técnica de Simulação e Modelagem.

\subsubsection{Objetivos Específicos}

- Comparar os resultados obtidos com os dados reais observados;

- Fazer um diagnóstico da situação operacional do Corredor de Exportação do Porto de Santos, e avaliar a operação com mais berços de atracação; 
- Aplicar a técnica de Simulação ao Corredor de Exportação, com a finalidade de estimar o impacto em relação ao congestionamento com a ocorrência de chuvas.

\subsection{Estrutura do Trabalho}

Este trabalho, além do capítulo de Introdução, é composto de 5 capítulos.

No capítulo 2, o referencial teórico aborda os principais modais de transporte, além do mercado da soja, englobando a cadeia produtiva, produção e consumo. O capítulo 3 discorre sobre o escoamento da soja pelos corredores de exportação presentes no Brasil.

No capítulo 4 é apresentada uma visão dos portos brasileiros em relação à sua movimentação, mercado e acessos, destacando problemas e investimentos futuros.

O capítulo 5 aborda a principal questão do estudo, a Simulação, onde são apresentadas conceituações, aplicações, vantagens, assim como a utilização do software Arena para o modelo proposto. São mostrados resultados obtidos no modelo atual e os cenários propostos.

No capítulo 6 são apresentadas as conclusões do presente estudo, e sugestões para próximas pesquisas. 


\section{Referencial Teórico}

\subsection{Modais de transporte}

Possuir uma infraestrutura eficiente, que propicie serviços com o menor custo possível, apresente os melhores resultados, atenda à demanda mediante uma adequada alocação de recursos normalmente escassos, é uma das condições indispensáveis para a obtenção de um crescimento econômico sustentável e para o efetivo desenvolvimento de um país.

Neste sentido, o transporte é uma das principais funções logísticas e passou a ocupar várias etapas na cadeia de suprimentos. Segundo Ballou (1995), quanto mais eficiente o sistema de transportes, maior a competitividade da empresa no mercado, garantia de economia de escala na produção e redução do preço dos materiais.

Para o processo de escolha do modal de transporte devem ser considerados alguns fatores tais como as características do mercado, carga a ser transportada, legislação vigente, infraestrutura de transportes e tecnologia. Segundo CaixetaFilho e Martins (2010), no Brasil, assim como Estados Unidos e Europa, a escolha do modal de transporte está associada aos serviços logísticos que são demandados pela competição em uma economia globalizada.

Os autores ainda afirmam que algumas variáveis são relevantes na escolha do modal, tais como: custo de operação, tempo em trânsito (transit time) entre os pares de origem-destino, frequência do serviço, disponibilidade e qualidade das informações do transporte, confiabilidade, capacidade, acessibilidade e flexibilidade de integração intermodal, segurança, perdas e danos.

Existem cinco modalidades de transportes: rodoviário, ferroviário, aquaviário, dutoviário e aéreo. De acordo com a matriz de transportes brasileira, apresentada na Tabela 1, é possível notar que há deficiências na infraestrutura brasileira de transportes, causadas principalmente pelo baixo investimento público, proporcionando um desbalanceamento da matriz de transportes. 
Tabela 1 - Matriz de Transporte Brasileira.

\begin{tabular}{|l|r|r|}
\cline { 2 - 3 } \multicolumn{1}{c|}{} & \multicolumn{1}{c|}{ Brasil } & \multicolumn{1}{c|}{ EUA } \\
\cline { 2 - 3 } \multicolumn{1}{c|}{} & \multicolumn{1}{c|}{$\%$} & $\%$ \\
\hline Ferroviário & 21,70 & 41,50 \\
\hline Rodoviário & 62,70 & 27,70 \\
\hline Aquaviário & 11,70 & 11,50 \\
\hline Dutoviário & 3,80 & 19,00 \\
\hline Aéreo & 0,10 & 0,30 \\
\hline
\end{tabular}

Fonte: Adaptado de ILOS (2008).

O modal rodoviário possui uma participação expressiva na matriz de transportes nacional quando comparado a outros países de dimensões continentais, tal como os Estados Unidos, que apresenta em sua matriz 41,5\% de uso do modal ferroviário, enquanto o modal rodoviário apresenta um valor muito abaixo da matriz brasileira, com $27,7 \%$.

Tais modais, ferroviário e aquaviário apresentam vantagens competitivas em trajetos de média e longa distância. Estes, quando comparados com o modal rodoviário, são superiores em eficiência energética e ambiental, custos de operação e capacidade de transporte.

De acordo publicação no portal do Departamento Nacional de Infraestrutura de Transportes (DNIT), a matriz de transporte brasileira deverá sofrer algumas mudanças. O Governo Brasileiro anunciou a construção de novas rodovias e investimentos em ferrovias, hidrovias e terminais intermodais, de modo a garantir competitividade aos produtos, integrar regiões e reduzir desigualdades. Além disso, há a expectativa que em 2025, 32\% do transporte de cargas do país será feito por meio de trens, um valor muito acima dos 21,7\% atuais (DNIT, 2011).

O transporte da soja nas diferentes etapas pode ser realizado por diferentes modais de transporte: rodoviário, ferroviário e hidroviário. Segundo Ojima (2004), pelo fato de a infraestrutura dos modais ferroviário e aquaviário serem deficientes e não suficientes para realizar o transporte da soja, é necessária a participação do modal rodoviário em grande parte da produção de soja brasileira, mesmo para longas distâncias.

Biaggioni e Bovolenta (2010) apontam a multimodalidade como alternativa para a logística no escoamento da soja. Pelo fato de cada modal apresentar custos e outros aspectos qualitativos, o uso de modais alternativos pode apresentar 
vantagens econômicas entre a origem e o destino de determinada mercadoria, resultando em um serviço de menor custo e melhor qualidade.

\subsubsection{Modal Rodoviário}

O modal rodoviário se caracteriza principalmente por ser mais disponível quando comparado com os outros modais. Segundo Novaes (2007), a grande vantagem deste modal é sua capacidade de levar produtos a qualquer local, principalmente no Brasil, onde há lugares em que esta é a única forma de transporte. Possui maior poder de acesso nas entregas de porta a porta, devido à disponibilidade da infraestrutura, sendo realizado em rodovias, estradas e ruas, as quais podem ser pavimentadas ou não, com utilização de veículos como caminhões e carretas.

Desta forma, este modal encontra-se em crescente expansão e muitas vezes priorizado entre todos os outros modais, já que flexibiliza os locais de entrega, além de permitir a transferência de mercadorias de um modal para outro. Outra vantagem é que os transportadores rodoviários conseguem ter um bom nível de serviço, onde se destacam a entrega da mercadoria no tempo esperado e o alcance de diversos locais para coleta e entrega.

Além disso, possui facilidade no carregamento do veículo, o que permite a rápida partida do mesmo; há a facilidade de substituir o veículo por outro, em caso de acidente ou quebra do veículo; permite o despacho de carga parcelada; e maior velocidade nas entregas porta a porta.

Além da sua limitação em capacidade, este modal também não possui muitas vantagens quando comparado com as ferrovias para ser usado em longas distâncias, pois é mais apropriado para pequenas e médias distâncias. Outro problema é o baixo valor dos fretes rodoviários praticados, que compromete o crescimento e desenvolvimento economicamente saudável dos outros modais.

O modal rodoviário representa $63 \%$ da matriz de transporte brasileira. Esta predominância fica evidente quando se observa o alcance da rede rodoviária no Brasil. Conforme o Plano CNT de Logística 2011, a malha rodoviária brasileira possui atualmente uma extensão de $1.580 .809 \mathrm{~km}$. Porém, apenas $212.618 \mathrm{~km}$ das pistas são pavimentadas, representando $13,4 \%$ da extensão total. 
Essas, por sua vez, estão distribuídas conforme a jurisdição da seguinte forma: $61.961 \mathrm{~km}$ de rodovias federais, $123.830 \mathrm{~km}$ de rodovias estaduais e $26.827 \mathrm{~km}$ de rodovias municipais. Foram avaliados $92.747 \mathrm{~km}$ de rodovias pavimentadas, onde $47,5 \%$ apresentavam alguma deficiência no pavimento, na sinalização e/ou na geometria da via. Isto retrata um cenário preocupante, onde a qualidade e a segurança do transporte de cargas são prejudicadas, restringindo a integração com os demais modais e gerando custos operacionais elevados.

A Pesquisa CNT de Rodovias de 2011 analisou a classificação geral por região geográfica brasileira. A partir da Figura 1, observa-se que a região Sudeste apresenta os melhores resultados no estado geral de suas rodovias. Em contra partida, devido à falta de investimentos, as regiões Norte e Nordeste apresentam os piores resultados.

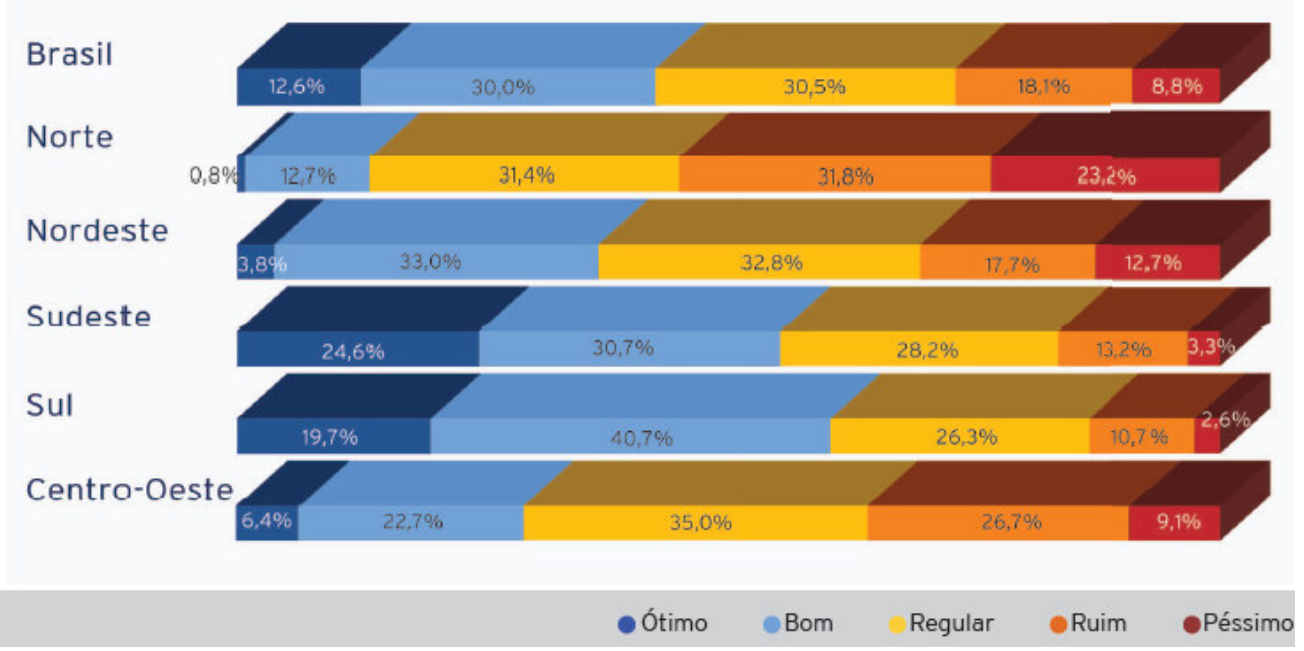

Figura 1 - Classificação Geral por Região Geográfica. Fonte: CNT (2011).

As consequências da baixa qualidade das rodovias brasileiras, de acordo com Associação Nacional dos Usuários do Transporte de Carga (ANUT) são: baixa produtividade, baixa confiabilidade, baixa velocidade média, elevado consumo de combustível, desgaste acelerado da frota, elevado índice de acidentes com mortes e falta generalizada de oferta de transporte no pico da safra.

Para o escoamento de commodities, Bulhões e Caixeta Filho (2000), acrescentam que o transporte rodoviário apresenta limitações, tornando-o pouco eficiente. Como o transporte de grãos no Brasil se dá através de grandes distâncias, o uso do modal rodoviário implicaria em altos custos dos fretes. 
Para Ojima (2004), os modais mais eficientes para escoamento de produtos com as características da soja produzida no Brasil são as ferrovias e hidrovias. Apesar de estes modais exigirem maior tempo de viagem, a capacidade de carga e a eficiência energética são muito elevadas quando comparadas com o modal rodoviário, gerando economia de custos e redução de perdas.

\subsubsection{Modal Ferroviário}

O transporte de cargas por ferrovias se caracteriza basicamente por ser um transporte que opera com grandes volumes de carga, com elevada eficiência energética, principalmente em casos de deslocamentos médios a grandes distâncias. Demanda grandes investimentos em operação dos terminais de carga e descarga, operação de estações, manutenção de equipamentos como: trilhos, dormentes, estações e sinalização, ou seja, os custos desta operação são em grande parte, custos fixos, assumidos diretamente pelas empresas operadoras.

Conforme o volume de utilização aumenta, o peso do custo fixo se reduz na mesma proporção (Novaes, 2007). Este modal está voltado, em sua maioria, para mercadorias de alto peso e baixo valor agregado, como grandes quantidades a granel, em geral commodities, ao contrário do modal rodoviário, como visto anteriormente, que visa o transporte de mercadorias de baixo volume e alto valor agregado.

Segundo Novaes (2007), o transporte ferroviário possui como benefício o baixo frete, se comparado com o modal rodoviário, além do baixo consumo de combustível por tonelada/quilômetro. Os custos de transporte por tonelada/quilômetro são reduzidos à medida que aumenta o número de unidades de transporte. Por outro lado, possui maior tempo de viagem e custo elevado, quando associado a distâncias pequenas e médias. Sua utilização está sujeita à disponibilidade de material rodante, além de possuir baixa flexibilidade e possuir rota fixa.

A pesquisa realizada pelo Instituto ILOS em 2008 apontou que apesar deste transporte sofrer com baixa disponibilidade de infraestrutura e com problemas de gestão, houve um crescimento na movimentação de produtos e insumos por este modal. Isto mostra que as empresas precisam cada vez mais do modal ferroviário para escoar sua produção. 
A mesma pesquisa aponta que os principais motivos para as empresas não utilizarem as ferrovias são: indisponibilidade de rotas, custo total elevado, indisponibilidade de vagões, falta de interesse da concessionária a transportar determinada mercadoria, baixa velocidade, problemas no transbordo, indisponibilidade de terminais e problemas com infraestrutura na interface portoferrovia.

Atualmente, a malha ferroviária brasileira em operação apresenta 29.817 km de extensão, sendo $28.066 \mathrm{~km}$ operados por empresas privadas, por meio de concessões (CNT, 2011). O Brasil apresenta, em média, densidade de 3,46 quilômetros de trilhos para cada mil quilômetros quadrados. Esta densidade apresenta um valor muito baixo quando comparado com outros países, por exemplo, a Alemanha, possui 135 quilômetros de trilhos para cada mil quilômetros quadrados.

Mesmo com a malha ferroviária permanecendo praticamente sem alterações há muitos anos, o DNIT (2011) afirmou que ampliações serão realizadas. Com a criação do "Plano Nacional de Viação Ferroviária", que integrará mais oito mil quilômetros de ferrovias à malha nacional, como a Nova Transnordestina, a Oeste-Leste, a Norte-Sul e a Ferrovia de Integração do Centro-Oeste, estima-se que a matriz brasileira de transportes, no ano 2025, atinja $32 \%$ pelo modal ferroviário, de acordo publicação no portal DNIT (2011).

Como se pode observar no mapa da Figura 2, há uma concentração do modal ferroviário no litoral brasileiro, além de existir uma lacuna no estado do Mato Grosso e a região Norte do Brasil. Por este motivo, é necessário o uso do modal rodoviário para o escoamento da soja do Mato Grosso. Com a estimativa de ampliação, a densidade ferroviária aumentará e a parte da região Centro-Oeste passará a ser atendida pelo modal. Deste modo, esta região e o oeste baiano, que são os maiores potenciais para o crescimento da fronteira agrícola brasileira, poderão utilizar este tipo de modal para escoarem sua produção. (ANTT, 2011). 


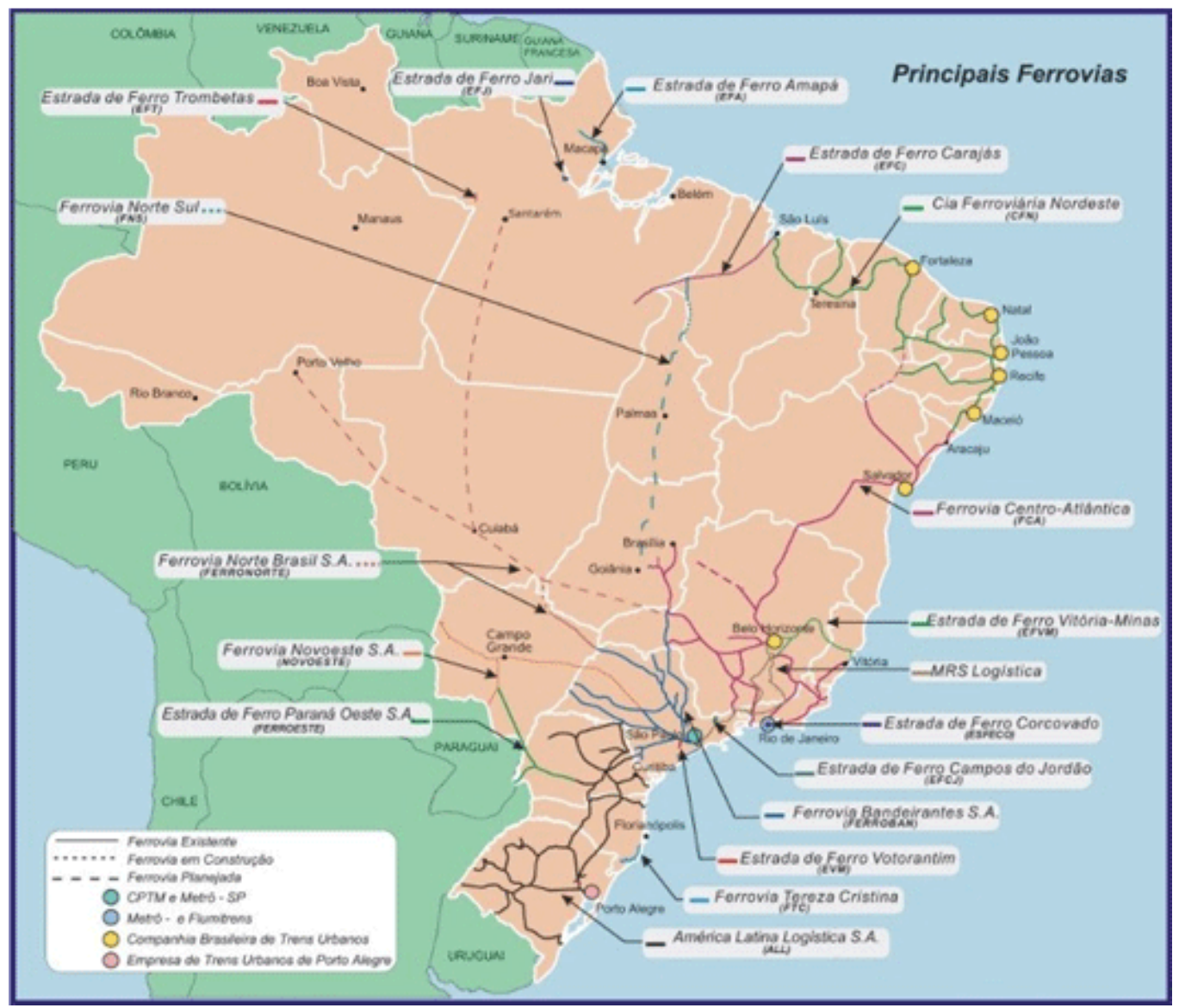

Figura 2 - Mapa ferroviário brasileiro.

Fonte: ANTT (2011).

\subsubsection{Modal Aquaviário}

O transporte aquaviário abrange todos os tipos de transporte que são realizados na água. Isto inclui o transporte em rios, lagos e oceanos dentro do próprio país ou por diferentes países. Este modal divide-se em dois subsistemas: o transporte fluvial e o transporte marítimo. $\mathrm{O}$ transporte fluvial é realizado em rios navegáveis, e o marítimo é feito pela costa oceânica.

Para o transporte marítimo existe o transporte marítimo de longo curso, que é usado para distâncias mais longas, como entre Brasil e outros países, e a navegação de cabotagem, que é usada para navegação na costa do próprio país. A cabotagem é composta por pequena cabotagem, que cobre somente portos nacionais, e a grande cabotagem, que inclui a navegação com países próximos ao Brasil.

Conforme o Plano CNT de Logística (2011), o Brasil possui aproximadamente 44 mil quilômetros de rios, dos quais 29 mil quilômetros são 
naturalmente navegáveis, mas apenas 13 mil quilômetros são efetivamente utilizados economicamente. Já a parte marítima tem cerca de 8 mil quilômetros de costa brasileira. O transporte aquaviário de cargas corresponde a $11,7 \%$ de toda a carga que é transportada no Brasil, segundo CNT. Quando comparado com a participação no transporte de cargas dos Estados Unidos, nota-se uma situação oposta à brasileira. De acordo com a Figura 3, no transporte de soja, os modais ferroviários e hidroviários americanos possuem participação expressiva. Concluise que o transporte de cargas feito dentro do Brasil pelo meio hidroviário é subutilizado e ainda retrata o descaso com estes modais por sua falta de investimentos.

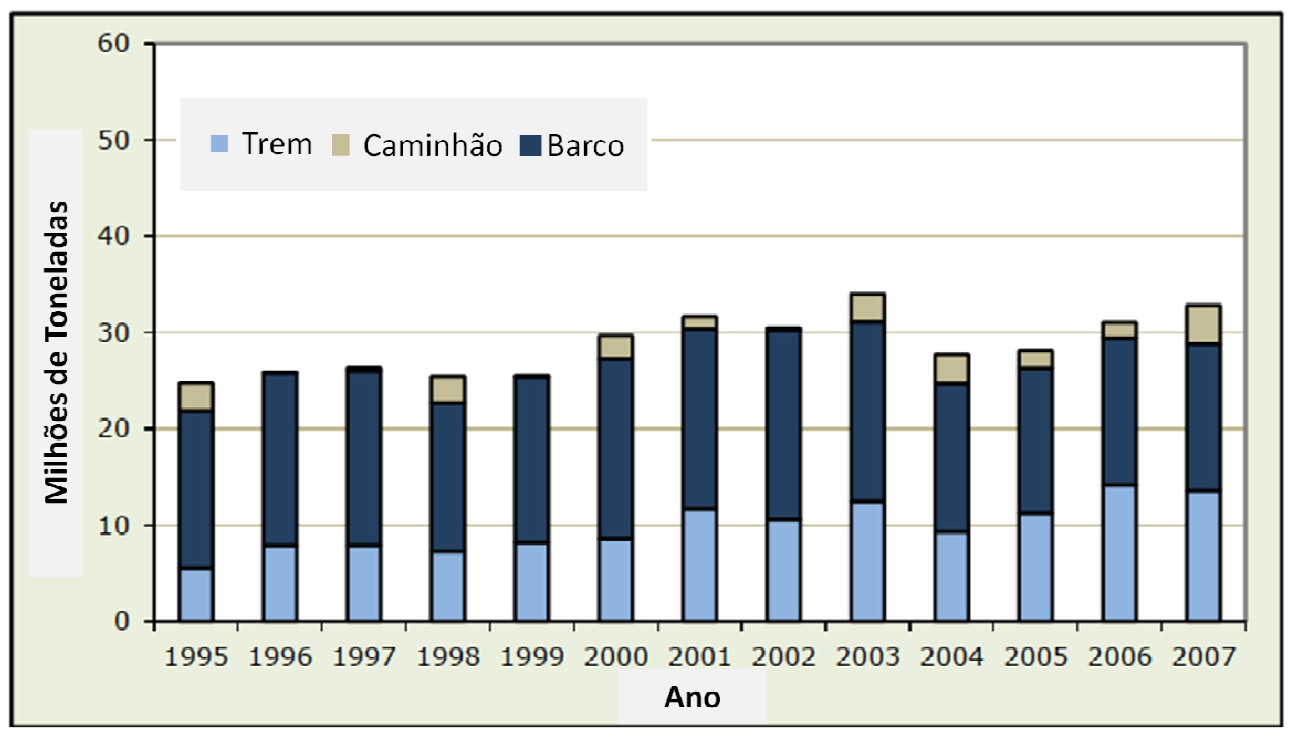

Figura 3 - Exportação de soja dos Estados Unidos por modal 1995-2007. Fonte: USDA (2011).

$\mathrm{Na}$ Figura 4 é possível verificar que os terminais intermodais aquaviários brasileiros, apresentam uma quantidade muito menor, quando comparado com os Estados Unidos. 

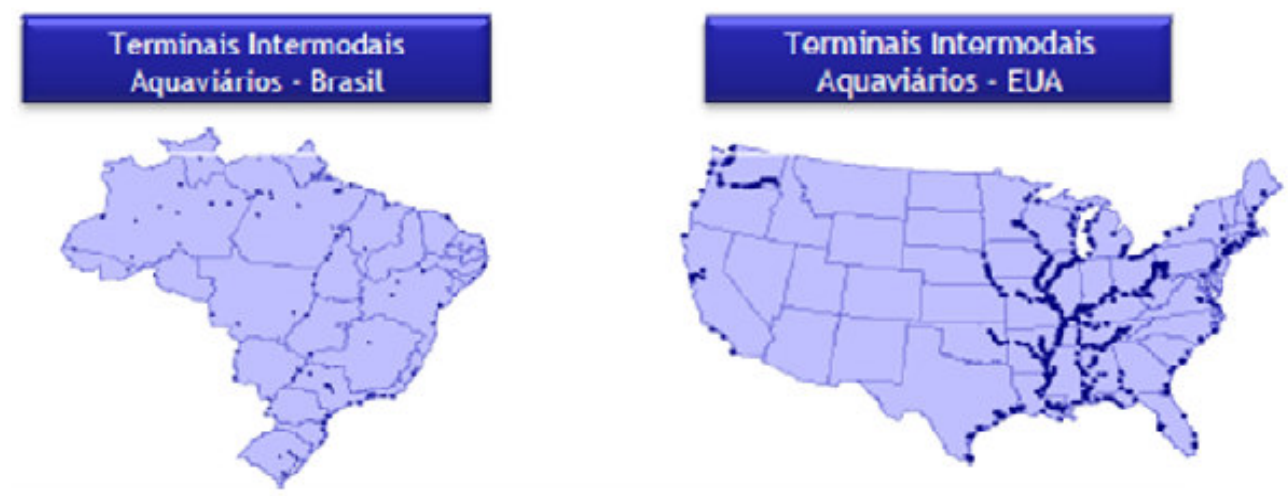

Figura 4 - Intermodalidade Brasil x EUA.

Fonte: Pesquisa CNT - COPPEAD (2011).

De acordo com a ANTAQ, o setor portuário movimenta anualmente cerca de 700 milhões de toneladas das mais diversas mercadorias e responde sozinho, por mais de $90 \%$ das exportações. Isto mostra que o sistema portuário representa uma função estratégica para a economia do país.

Devido à crise energética ocorrida na década de 70, novas opções de transporte surgiram, para gerar ganhos em eficiência, menor consumo de combustível e aumento na capacidade de carregamento. Com isto, novidades foram trazidas para aumentar a velocidade no processo de carga e descarga dos navios, tais como aumento no porte das embarcações, automatização nos sistemas operacionais, implementação de sistemas para reduzir o consumo de combustível, e novos tipos de embarcações foram desenvolvidas.

O transporte aquaviário depende de terminais portuários para que seja feito o manuseio da carga, embora existam navios e barcaças que permitam o transbordo diretamente de outros navios ou barcaças. A maioria dos terminais portuários é construída por órgãos do governo e operada por suas agências locais que podem também operar seus armazéns.

Embora estas agências locais sejam usuárias do transporte aquaviário, investem e operam seus próprios terminais que atendem às suas necessidades especiais de manuseio e armazenagem de carga. Estas empresas possuem como principal comercialização commodities, como grãos, carvão e óleo. Pelas hidrovias brasileiras, o transporte de commodities se torna facilitado pela formação de polos comerciais e industriais localizados às suas margens, atuando de forma integrada com os demais modais que venham a complementar o transporte fluvial. 
Em relação à composição de custos deste modal, caracteriza-se por um grande percentual de custos variáveis e baixo percentual de custos fixos. Este transporte não precisa ter suas próprias vias, pois a própria natureza já oferece. Estas são mantidas, pelo governo, através de cobranças de taxas de manutenção, de acordo com o volume de negócios operados.

Este é um modal economicamente viável, eficiente, exige menos investimentos nas fases de implantação e manutenção, além disso, traz baixo impacto ambiental em relação aos demais modais, além do desafogamento das estradas e da diminuição da necessidade de investimentos na conservação e na construção de novas rodovias.

A principal vantagem deste modal é o seu baixo custo, além do alto volume de capacidade de carregamento. De acordo com Fleury (2002), o modal aquaviário praticamente não possui limitações para o tipo de produto e volume a ser transportado. Possui maior eficiência energética, maior vida útil da infraestrutura e dos equipamentos e veículos, e maior capacidade de concentração da carga. Consome menos combustível, emite menos poluente, e ruídos, gerando menor impacto ambiental.

O modal aquaviário apresenta como desvantagens o fato de a carga sofrer vários transbordos, estando sujeita a intempéries, ou seja, é necessário um custo maior para as embalagens, de modo a não danificar a carga. Além disso, o acesso à via de transporte é difícil. Caso o usuário deste modal não esteja próximo a rios, terá de ser utilizado outro modal para concluir o transporte até o porto e conseguir exportar a carga. Os principais portos brasileiros estão representados na Figura 5. 


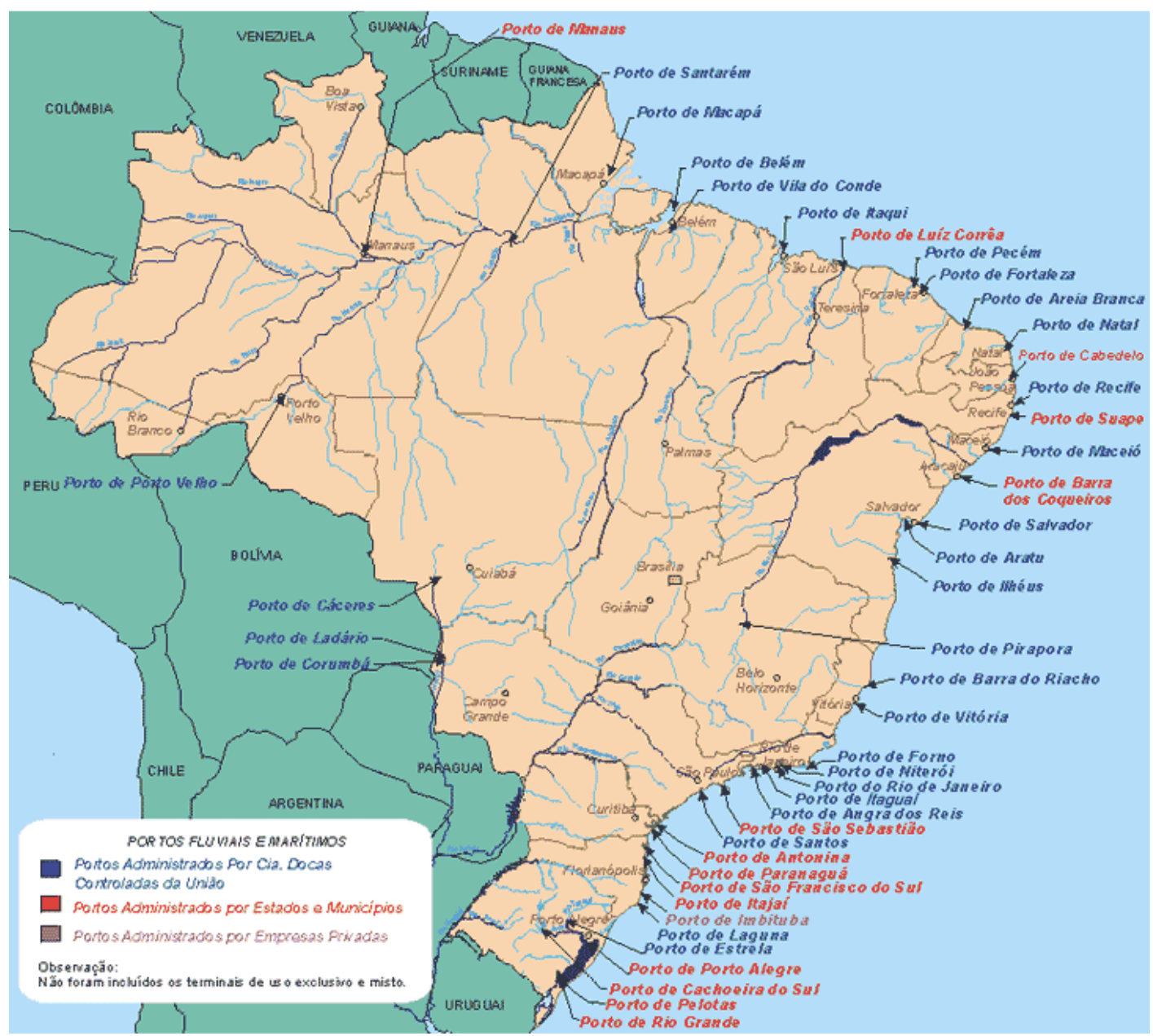

Figura 5 - Principais portos brasileiros.

Fonte: ANTAQ (2010).

Segundo Ojima (2004), para o escoamento de soja brasileira, a infraestrutura ferroviária e hidroviária é insuficiente para o transporte de grãos, fazendo-se necessário o uso do modal rodoviário, inclusive para longas distâncias. Com isto, observa-se um baixo aproveitamento do transporte aquaviário. Um caminhão carrega cerca de 150 vezes menos soja do que uma composição ferroviária e cerca de 600 vezes menos do que um comboio de barcaças numa hidrovia como a do Rio Madeira.

\subsection{O mercado da soja}

Mundialmente, a soja é uma cultura de grande importância dado que, de 1970 a 2007, o crescimento de sua produção global foi de 44 milhões de toneladas para 236 milhões de toneladas, apresentando aumento de $436 \%$, enquanto outros granéis, como milho, arroz, cevada, cresceram próximo a um terço deste valor. 
Segundo a EMBRAPA, a safra de 2010/2011 teve a produção mundial de 263,7 milhões de toneladas, com 103,5 milhões de hectares de área plantada.

No contexto mundial, o Brasil segue como o segundo maior produtor de soja, com 75,3 milhões de toneladas produzidas em 2010/2011, ficando atrás dos Estados Unidos (maior produtor mundial do grão), com 90,6 milhões de toneladas produzidas na safra de 2010/2011. Devido a isto, a soja é um produto de grande importância para o país, sendo a principal cultura explorada no mercado interno. Por ser a principal fonte de proteína para a indústria da alimentação animal, a produção de soja tem crescido de forma suficiente para atender à demanda total por esse produto. $\mathrm{O}$ baixo custo na produção brasileira se deve à mão de obra barata, tecnologia avançada e produção em escala. Estes fatores geram ganho de competitividade, porém são amortizados pela carência de investimentos em logística.

O valor exportado pelo agronegócio brasileiro atingiu no período de agosto de 2010 a julho de 2011, US\$ 85,7 bilhões. Este valor representa um crescimento de 23,7\% em relação aos 12 meses anteriores. Para o complexo soja, no mesmo período mencionado anteriormente, as exportações chegaram a US\$ 7,5 bilhões, frente a US\$ 4,6 bilhões para o período de agosto de 2009 a julho de 2010, tendo um crescimento de $63 \%$.

Atualmente, de acordo com a Companhia Nacional de Abastecimento (CONAB, 2012), a produção de soja no Brasil é liderada pelos estados de Mato Grosso, Paraná, Rio Grande do Sul e Goiás. Estes produziram em 2011, 73,7\% da soja nacional. Segundo CONAB, 2012, a região do Centro Oeste brasileiro, em 2011, atuou como a principal região produtora de soja do país, com 45,0\% da produção nacional. Alguns fatores contribuíram para que esta região alcançasse este resultado (Embrapa, 2007):

- Incentivos fiscais para o estabelecimento de agroindústrias produtoras e processadoras de grãos;

- Incentivos fiscais para novas áreas agrícolas e aquisição de maquinário;

- Durante as décadas de 1960 a 1980, as terras possuíam valor inferior às terras da região sul. A região sul foi a região pioneira no cultivo de soja no país;

- A região Centro Oeste proporciona além de condições físicas favoráveis ao cultivo da soja, topografia plana, facilitando o uso de 
máquinas e equipamentos de grande porte. Com isto, gera maior rendimento das máquinas, tendo, como consequência economia em mão de obra;

- Apesar de ainda precário, o sistema de transportes da região apresentou algumas melhorias no corredor de exportação, que utiliza rodovias e ferrovias.

\subsubsection{Cadeia produtiva da soja no Brasil}

A soja teve sua origem no sudoeste asiático e devido a expansões em suas aplicações, possui hoje uma importante participação na economia do país. Segundo a Embrapa (2007), a soja expandiu-se pela China e houve tentativas de introdução comercial do cultivo do grão na Rússia, Inglaterra e Alemanha. Essas tentativas foram fracassadas, provavelmente devido às condições climáticas desfavoráveis. Já no Brasil, a soja foi introduzida na década de 1930 e no final da década de 60 o país começou a enxergar a soja como um produto comercial, influenciando o cenário mundial de produção do grão.

De acordo com a Embrapa, a partir dos anos 70, os preços praticados aumentaram e surgiu um interesse maior pelos agricultores e pelo mercado brasileiro. Pelo fato de a safra brasileira ser escoada na entressafra americana e com isto, as cotações atingidas serem maiores, o país passou a ter uma vantagem competitiva em relação aos outros produtores. O Brasil desenvolveu tecnologia para a adaptação do grão às condições brasileiras. Atualmente, a soja é a principal oleaginosa produzida, com $57 \%$ da produção média mundial de grãos fornecedores de óleos, sendo os principais produtores os países: Estados Unidos, Brasil, Argentina, China, Índia e Paraguai.

Atualmente, a soja é utilizada nas indústrias de produtos alimentícios, ração animal, indústrias diversas, ou para combustível. Com isto surge mais espaço para a soja que é o principal substituto para diversos outros grãos, devido à sua versatilidade. Seu uso mais conhecido, no entanto, é como óleo refinado, obtido a partir do óleo bruto. No Brasil, a soja é quase exclusivamente consumida na forma de óleo e de farelo.

A cadeia produtiva da soja é apresentada na Figura 6, com sua estrutura e agentes envolvidos na cadeia. 


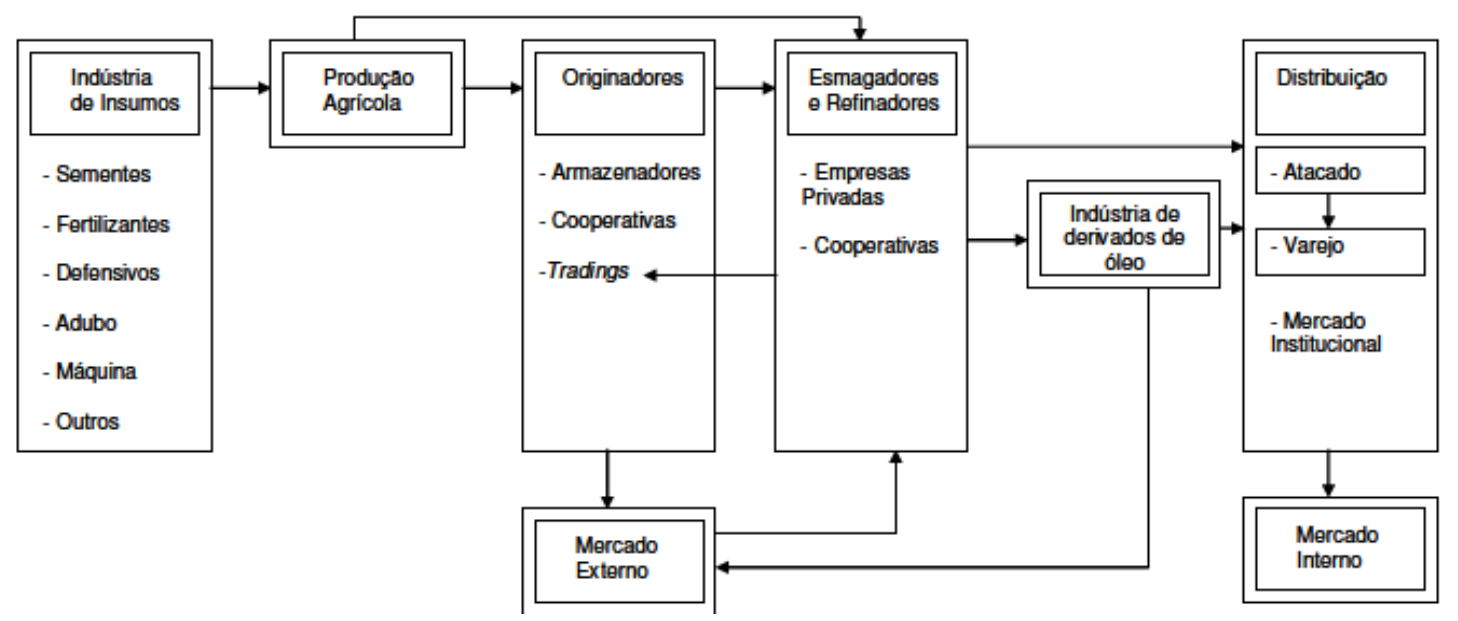

Figura 6 - Cadeia produtiva da soja.

Fonte: Adaptado Lazzarini e Nunes (2000).

A indústria de insumos é representada pela indústria de fertilizantes, defensivos e máquinas agrícolas capazes de suprir a demanda dos produtores agrícolas com insumos necessários à produção. Em seguida, para atender à demanda, a produção da soja é enviada aos armazéns, cooperativas ou tradings. As tradings possuem a tarefa de comercializar e acompanhar este processo no mercado doméstico ou internacional. Nesta etapa, o custo do transporte entre o produtor, e o armazém ou esmagadora, é elevado, já que algumas estradas não possuem pavimentação; são necessários grandes deslocamentos; é lento e provoca desgaste do veículo.

Segundo Dubke (2006), o processo de industrialização da soja tem seu início com a secagem e limpeza do grão, quebra e prensagem. Como resultado origina-se o óleo e uma massa que é lavada com solvente. A partir de uma tonelada de soja em grão, produz-se aproximadamente 780 quilos de farelo de soja e 19 quilos de óleo.

Além da soja em grão, também são comercializados a soja em farelo e seu óleo. O grão é previamente enviado para as esmagadoras e refinadoras. Algumas tradings possuem suas próprias esmagadoras e refinadoras, realizando uma integração vertical. Parte do farelo é exportada por meio de tradings ou pelas indústrias, e a outra parte é destinada à indústria de rações que está vinculada à indústria de carnes no mercado interno.

No caso do óleo, este segue para o esmagamento, degomagem e refino. O óleo parcialmente refinado pode ser transformado em vários sub-produtos, dos 
quais o principal é a margarina. Após este processo, os produtos são distribuídos para atacadistas e varejistas ou são enviados para o mercado internacional, através da exportação pelo modal marítimo.

As indústrias esmagadoras são muito importantes para a cadeia da soja, já que estas agregam valor ao produto. De acordo com a Tabela 2, é possível verificar que, em 2010, a maior concentração destas indústrias se localizava na região Sul $(39,9 \%)$ e na região Centro Oeste (38\%). Muitas das empresas esmagadoras estão presentes nos principais portos do país. Para esta indústria, há a tendência de deslocamento para locais mais próximos dos portos brasileiros. Isto é um diferencial competitivo para as exportações e um facilitador para o processo.

Tabela 2 - Capacidade instalada de processamento da soja no Brasil.

\begin{tabular}{|c|c|c|c|c|c|c|c|c|c|c|c|}
\hline Estado & UF & 2002 & 2003 & 2004 & 2005 & 2006 & 2007 & 2008 & 2009 & 2010 & $\%$ \\
\hline Mato Grosso & MT & 14.500 & 14.500 & 20.600 & 21.000 & 21.400 & 22.000 & 24.800 & 29.300 & 36.600 & 20,7 \\
\hline Paraná & PR & 28.650 & 28.950 & 31.765 & 32.115 & 32.950 & 33.850 & 35.150 & 34.150 & 35.645 & 20,2 \\
\hline Rio Grande do Sul & RS & 20.150 & 20.100 & 19.700 & 21.200 & 23.600 & 24.800 & 25.800 & 28.500 & 30.400 & 17,2 \\
\hline Goiás & GO & 9.060 & 10.320 & 16.920 & 18.150 & 18.800 & 19.650 & 19.250 & 20.050 & 20.950 & 11,8 \\
\hline São Paulo & $\mathrm{SP}$ & 12.950 & 14.450 & 14.950 & 15.600 & 16.400 & 16.650 & 17.780 & 17.780 & 16.880 & 9,5 \\
\hline Mato Grosso do Sul & MS & 6.630 & 6.980 & 7.295 & 8.295 & 9.360 & 9.560 & 9.575 & 12.725 & 10.225 & 5,8 \\
\hline Minas Gerais & MG & 6.450 & 6.350 & 6.400 & 6.600 & 6.600 & 6.600 & 6.600 & 6.800 & 9.100 & 5,1 \\
\hline Bahia & $\mathrm{BA}$ & 5.460 & 5.460 & 5.344 & 5.344 & 5.500 & 5.500 & 5.530 & 5.530 & 5.500 & 3,1 \\
\hline Santa Catarina & $\mathrm{SC}$ & 4.050 & 4.000 & 4.034 & 4.034 & 4.034 & 4.034 & 4.034 & 4.034 & 4.334 & 2,5 \\
\hline Piauí & $\mathrm{PI}$ & 260 & 1.760 & 2.360 & 2.360 & 2.460 & 2.460 & 2.530 & 2.530 & 2.600 & 1,5 \\
\hline Amazonas & AM & 2.000 & 2.000 & 2.000 & 2.000 & 2.000 & 2.000 & 2.000 & 2.000 & 2.000 & 1,1 \\
\hline Maranhão & MA & - & - & - & - & - & 2.000 & 2.000 & 1.500 & 1.500 & 0,8 \\
\hline Rondônia & RO & - & - & - & - & - & - & - & - & 700 & 0,4 \\
\hline Pernambuco & $\mathrm{PE}$ & 400 & 400 & 400 & 400 & 400 & 400 & 400 & 400 & 400 & 0,2 \\
\hline Ceará & $\mathrm{CE}$ & - & - & - & - & - & 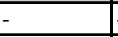 & - & - & - & 0 \\
\hline TOTAL & & 110.560 & 115.270 & 131.768 & 137.098 & 143.504 & 149.504 & 155.449 & 165.299 & 176.834 & 100 \\
\hline
\end{tabular}

Fonte: Adaptado de ABIOVE (2010).

\subsubsection{Produção e consumo da soja no Brasil}

A produção brasileira de soja estimada em 66,3 milhões de toneladas para a safra de 2011/2012 recuou em relação ao o ritmo de crescimento das últimas safras. Este volume é $-11,9 \%$ ou 9,84 milhões de toneladas inferiores à produção obtida na safra 2010/2011, quando foram colhidas 75,37 milhões de toneladas. As condições climáticas adversas caracterizada por estiagens prolongadas causadas pelo fenômeno "La Niña" foram os responsáveis pelo resultado negativo da safra (CONAB, 2012).

A partir da Tabela 3, é possível afirmar que a região Centro Oeste continua como maior produtora de soja no país com crescimento de $2,8 \%$ entre as safras de 
2010/2011e 2011/2012. Em seguida, segue a região Sul, com produção de 18,55 milhões toneladas de soja para a safra de 2011/2012.

Tabela 3 - Soja: Comparativo de Área, Produtividade e Produção.

\begin{tabular}{|c|c|c|c|c|c|c|c|c|c|}
\hline \multirow[b]{2}{*}{ REGIÃO/UF } & \multicolumn{3}{|c|}{ ÁREA (Em mil ha) } & \multicolumn{3}{|c|}{ PRODUTIVIDADE (Em kg/ha) } & \multicolumn{3}{|c|}{ PRODUÇÃO (Em mil t) } \\
\hline & $\begin{array}{c}\text { Safra 10/11 } \\
\text { (a) }\end{array}$ & $\begin{array}{c}\text { Safra 11/12 } \\
\text { (b) }\end{array}$ & $\begin{array}{c}\text { VAR. \% } \\
\text { (b/a) }\end{array}$ & $\begin{array}{c}\text { Safra 10/11 } \\
\text { (c) }\end{array}$ & $\begin{array}{l}\text { Safra 11/12 } \\
\text { (d) }\end{array}$ & $\begin{array}{c}\text { VAR. \% } \\
\text { (d/c) }\end{array}$ & $\begin{array}{c}\text { Safra 10/11 } \\
\text { (e) }\end{array}$ & $\begin{array}{l}\text { Safra 11/12 } \\
\text { (f) }\end{array}$ & $\begin{array}{l}\text { VAR. } \% \\
\text { (f/e) }\end{array}$ \\
\hline NORTE & 645,5 & 717,6 & 11,2 & 3.063 & 3.027 & $(1,2)$ & $1.977,2$ & $2.172,2$ & 9,9 \\
\hline $\mathrm{RR}$ & 3,7 & 3,7 & - & 2.800 & 2.800 & - & 10,4 & 10,4 & - \\
\hline RO & 132,3 & 143,5 & 8,5 & 3.215 & 3.221 & 0,2 & 425,3 & 462,2 & 8,7 \\
\hline $\mathrm{PA}$ & 104,8 & 119,2 & 13,7 & 3.000 & 2.657 & $(11,4)$ & 314,4 & 316,7 & 0,7 \\
\hline TO & 404,7 & 451,2 & 11,5 & 3.032 & 3.065 & 1,1 & $1.227,1$ & $1.382,9$ & 12,7 \\
\hline NORDESTE & $1.945,7$ & $2.117,1$ & 8,8 & 3.213 & 2.880 & $(10,4)$ & $6.251,5$ & $6.096,3$ & $(2,5)$ \\
\hline MA & 518,2 & 559,7 & 8,0 & 3.087 & 2.949 & $(4,5)$ & $1.599,7$ & $1.650,6$ & 3,2 \\
\hline $\mathrm{PI}$ & 383,6 & 444,6 & 15,9 & 2.983 & 2.841 & $(4,8)$ & $1.144,3$ & $1.263,1$ & 10,4 \\
\hline BA & $1.043,9$ & $1.112,8$ & 6,6 & 3.360 & 2.860 & $(14,9)$ & $3.507,5$ & $3.182,6$ & $(9,3)$ \\
\hline CENTRO-OESTE & $10.819,4$ & $11.495,2$ & 6,2 & 3.137 & 3.036 & $(3,2)$ & $33.938,9$ & $34.904,8$ & 2,8 \\
\hline MT & $6.398,8$ & $6.980,5$ & 9,1 & 3.190 & 3.130 & $(1,9)$ & $20.412,2$ & $21.849,0$ & 7,0 \\
\hline MS & $1.760,1$ & $1.815,0$ & 3,1 & 2.937 & 2.550 & $(13,2)$ & $5.169,4$ & $4.628,3$ & $(10,5)$ \\
\hline GO & $2.605,6$ & $2.644,7$ & 1,5 & 3.140 & 3.120 & $(0,6)$ & $8.181,6$ & $8.251,5$ & $\overline{0,9}$ \\
\hline $\mathrm{DF}$ & 54,9 & 55,0 & 0,2 & 3.200 & 3.200 & - & 175,7 & 176,0 & 0,2 \\
\hline SUDESTE & $1.636,9$ & $1.606,2$ & $(1,9)$ & 2.824 & 2.899 & 2,7 & 4.622,1 & $4.656,3$ & 0,7 \\
\hline MG & $1.024,1$ & $1.024,0$ & $(0,0)$ & 2.845 & 2.987 & 5,0 & $2.913,6$ & $3.058,7$ & 5,0 \\
\hline SP & 612,8 & 582,2 & $(5,0)$ & 2.788 & 2.744 & $(1,6)$ & $1.708,5$ & $1.597,6$ & $(6,5)$ \\
\hline SUL & $9.133,5$ & $9.106,1$ & $(0,3)$ & 3.124 & 2.037 & $(34,8)$ & $28.534,6$ & $18.553,4$ & $(35,0)$ \\
\hline PR & $4.590,5$ & $4.460,6$ & $(2,8)$ & 3.360 & 2.453 & $(27,0)$ & $15.424,1$ & $10.941,9$ & $(29,1)$ \\
\hline $\mathrm{SC}$ & 458,2 & 448,3 & $(2,2)$ & 3.250 & 2.420 & $(25,5)$ & $1.489,2$ & $1.084,9$ & $(27,1)$ \\
\hline RS & $4.084,8$ & $4.197,2$ & 2,8 & 2.845 & 1.555 & $(45,3)$ & $11.621,3$ & $6.526,6$ & $(43,8)$ \\
\hline NORTE/NORDEST| & $2.591,2$ & $2.834,7$ & 9,4 & 3.176 & 2.917 & $(8,2)$ & $8.228,7$ & $8.268,5$ & 0,5 \\
\hline CENTRO-SUL & $21.589,8$ & $22.207,5$ & 2,9 & 3.108 & 2.617 & $(15,8)$ & $67.095,6$ & $58.114,5$ & $(13,4)$ \\
\hline BRASIL & $24.181,0$ & $25.042,2$ & 3,6 & 3.115 & 2.651 & $(14,9)$ & $75.324,3$ & $66.383,0$ & $(11,9)$ \\
\hline
\end{tabular}

Fonte: CONAB (2012).

A região Sul, com seu segundo lugar no ranking das regiões brasileiras produtoras de soja, evidencia a estratégia que os produtores adotaram nos últimos anos, de substituir pastagens e áreas de milho na safra de verão pelo cultivo da soja. Porém, no médio e longo prazo, a taxa de crescimento do plantio de soja deverá recuar para esta região, por haver limitações de novas áreas para expansão.

Com isto, a região Centro Oeste, permanecerá liderando o fornecimento de áreas para o cultivo de soja. Além disso, a produção de soja em grãos está evoluindo também para novas áreas no Maranhão, Tocantins, Piauí e Bahia, que respondem por $10,3 \%$ da produção brasileira. Conforme o Ministério da Agricultura, Pecuária e Abastecimento (MAPA), na Figura 7, é apresentada a participação das regiões brasileiras, em 2011/2012, com destaque para as regiões Sul e Centro-Oeste, as quais representam, respectivamente, $34,3 \%$ e $47,6 \%$ do total da produção brasileira de soja em grão. 


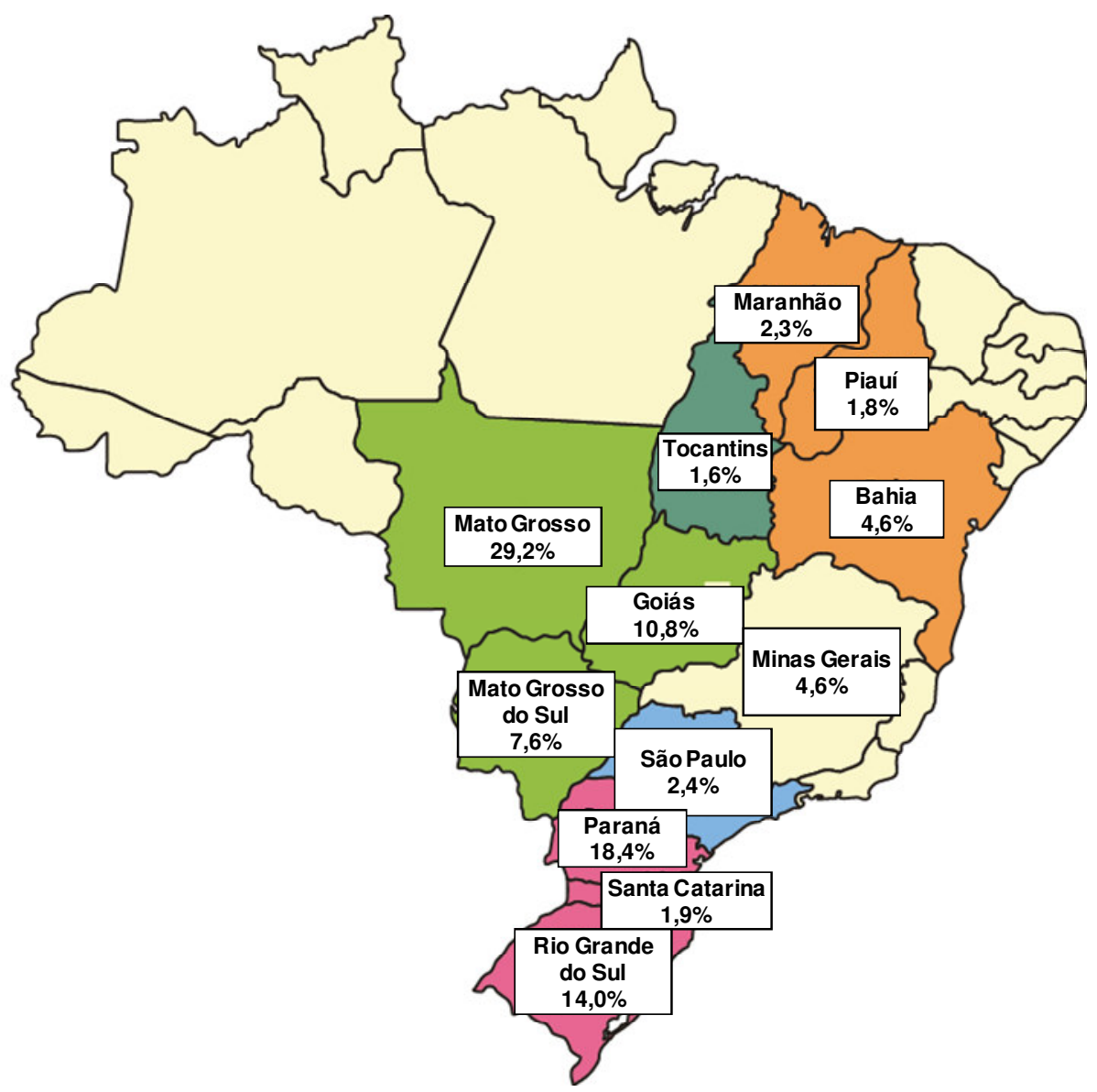

Figura 7 - Produção da soja em grãos no Brasil: participação das regiões (\%). Fonte: Adaptado de MAPA (2012).

A estimativa para a produção da soja em grão para a safra de 2021/2022 é de 88,9 milhões de toneladas. A produção teria a taxa de crescimento de 2,3\% ao ano, para os próximos dez anos, sendo esta acima da taxa mundial para os próximos dez anos, estimada pelo Food and Agricultural Policy Research Institute, em 0,84\% (MAPA, 2012).

De acordo com Figura 8, as exportações projetadas para o período de 2021/2022 são de 44,9 milhões de toneladas de soja em grão. Para o consumo de soja em grãos, a projeção para a safra de 2021/2022 é de 49,5 milhões de toneladas. Este aumento em relação à 2011/2012 se deve ao fato de a soja em grãos ser um componente essencial na fabricação de rações animais e adquire importância crescente na alimentação humana. 


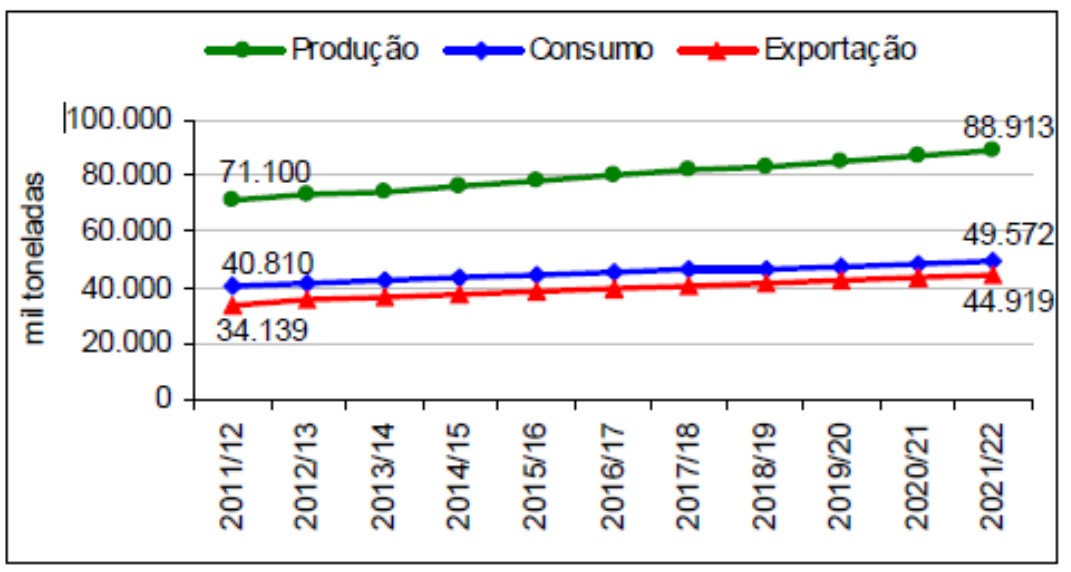

Figura 8 - Produção, exportação e consumo de Soja. Fonte: MAPA (2012).

Para o farelo de soja, o consumo deve crescer em 2,5\% ao ano e o óleo de soja deverá crescer a uma taxa anual de 2,2\% no período 2010/11 a 2021/2022. Para a produção de óleo de soja, projeta-se que $78 \%$ serão consumidos internamente. A maior parte deste consumo será destinada ao consumo humano e a outra parte para a produção de biodiesel. Os $22 \%$ restantes serão destinados à exportação. O farelo de soja terá possivelmente $50 \%$ de sua produção para consumo interno e a outra metade para exportação (MAPA, 2012).

De acordo com a CONAB, segundo a Tabela 4, as exportações do complexo soja (grão, farelo e óleo), no ano de 2011, representaram o total de US\$24,1 bilhões. Para a soja em grão o total exportado foi de US\$11,0 bilhões $(29,1$ milhões toneladas). Para o farelo de soja foram exportados US $\$ 4,7$ bilhões $(13,7$ milhões toneladas) e para o óleo de soja US\$ 1,4 bilhões (1,6 milhões toneladas).

As exportações brasileiras do complexo soja estão concentradas para a China e países da Europa. A China é a principal compradora de soja em grãos brasileira e apresenta crescimento nas aquisições do grão, representando $34 \%$ das exportações brasileiras de soja em grãos. 
Tabela 4 - Complexo Soja: Exportações Brasileiras, por Países de Destino.

\begin{tabular}{|c|c|c|c|c|c|c|}
\hline \multirow[b]{2}{*}{ Países de Destino } & \multicolumn{2}{|c|}{2009} & \multicolumn{2}{|c|}{2010} & \multicolumn{2}{|c|}{2011} \\
\hline & Quant(t) & $\begin{array}{l}\text { Valor FOB } \\
\text { US } \$ 1000\end{array}$ & Quant(t) & $\begin{array}{l}\text { Valor FOB } \\
\text { US } \$ 1000\end{array}$ & Quant.(t) & $\begin{array}{l}\text { Valor FOB } \\
\text { US } \$ 1000\end{array}$ \\
\hline \multicolumn{7}{|l|}{$\overline{\text { GRÃO }}$} \\
\hline Alemanha & 1.116 .132 & 453.783 & 355.219 & 134.551 & 370.819 & 189.032 \\
\hline China & 15.939 .968 & 6.342 .965 & 19.064 .458 & 7.133 .441 & 22.104 .719 & 10.957 .102 \\
\hline Espanha & 2.114 .646 & 791.909 & 1.874 .991 & 740.227 & 2.369 .270 & 1.192 .918 \\
\hline França & 384.243 & 150.703 & 105.886 & 45.026 & 221.774 & 107.530 \\
\hline Itália & 728.165 & 278.508 & 568.700 & 213.133 & 150.662 & 73.269 \\
\hline Japão & 586.781 & 245.863 & 507.332 & 192.576 & 536.111 & 253.805 \\
\hline Países Baixos & 2.366 .889 & 974.310 & 1.437 .354 & 550.551 & 1.520 .683 & 710.252 \\
\hline Outros & 5.325 .882 & 2.186 .242 & 5.159 .215 & 2.033 .496 & 5.711 .523 & 2.843 .378 \\
\hline Soma & 28.562 .705 & 11.424.283 & 29.073 .156 & 11.043 .000 & 32.985 .560 & 16.327 .287 \\
\hline \multicolumn{7}{|l|}{ FARELO } \\
\hline Alemanha & 1.153 .760 & 437.098 & 1.225 .669 & 442.137 & 1.366 .110 & 574.733 \\
\hline China & 1.635 & 640 & - & - & 20.538 & 9.056 \\
\hline Dinamerca & 81.447 & 35.648 & 204.760 & 76.927 & 166.563 & 69.639 \\
\hline Espanha & 575.381 & 210.355 & 586.158 & 190.101 & 612.790 & 224.760 \\
\hline França & 2.439 .303 & 889.180 & 2.330 .689 & 789.389 & 2.053 .273 & 770.147 \\
\hline Irã, Rep. & 361.053 & 130.426 & 262.993 & 84.377 & 409.844 & 155.753 \\
\hline Itália & 275.293 & 106.831 & 268.424 & 92.883 & 267.332 & 106.157 \\
\hline Países Baixos & 2.571 .265 & 979.114 & 3.398 .306 & 1.211 .869 & 3.914 .624 & 1.640 .446 \\
\hline Tailândia & 932.554 & 347.922 & 1.324 .428 & 468.738 & 1.413 .457 & 563.098 \\
\hline Outros & 3.861 .298 & 1.455 .437 & 4.067 .173 & 1.362 .952 & 4.130 .638 & 1.584 .072 \\
\hline Soma & 12.252 .990 & 4.592 .651 & 13.668 .599 & 4.719 .373 & 14.355 .169 & 5.697 .860 \\
\hline \multicolumn{7}{|c|}{ ÓLEO BRUTO, REFNADO E OUTROS } \\
\hline Bangladesh & 123.526 & 97.282 & 37.500 & 32.851 & 106.700 & 129.476 \\
\hline China & 529.105 & 406.951 & 935.965 & 786.420 & 643.179 & 763.682 \\
\hline Hong Kong & 17.709 & 13.343 & 12.500 & 11.028 & 20.152 & 23.420 \\
\hline Índia & 169.844 & 132.289 & 85.372 & 71.721 & 141.950 & 173.573 \\
\hline Irã, Rep. & 72.100 & 48.512 & 85.963 & 81.870 & 65.345 & 79.884 \\
\hline Países Baixos & 5.732 & 3.743 & 232 & 305 & 2.961 & 3.918 \\
\hline Outros & 675.634 & 531.805 & 406.229 & 368.234 & 761.127 & 955.317 \\
\hline Soma & 1.593 .649 & 1.233 .925 & 1.563 .761 & 1.352 .429 & 1.741 .413 & 2.129 .270 \\
\hline
\end{tabular}

Fonte: Adaptado de CONAB (2012).

Para os principais alimentos consumidos mundialmente, representados na

Tabela 5, é possível observar que a soja brasileira em grão deverá ter uma participação significativa em 2021/2022, com aumento de $25,1 \%$.

Tabela 5 - Principais Tendências da Produção 2011/12 a 2021/22.

\begin{tabular}{|l|l|r|r|r|}
\hline \multicolumn{1}{|c|}{ Grãos } & Unidade & \multicolumn{1}{c|}{$\mathbf{2 0 1 1 / 1 2}$} & \multicolumn{1}{c|}{$\mathbf{2 0 2 1 / 2 2}$} & \multicolumn{1}{c|}{ Aumento \% } \\
\hline Arroz & Mil t & 13.208 & 15.242 & 15,4 \\
\hline Feijão & Mil t & 3.630 & 4.093 & 12,8 \\
\hline Milho & Mil t & 59.651 & 70.421 & 18,1 \\
\hline Soja Grão & Mil t & 71.100 & 88.913 & 25,1 \\
\hline Trigo & Mil t & 5.680 & 6.937 & 22,1 \\
\hline Total & Milhões t & $\mathbf{1 5 3 . 2 6 9}$ & $\mathbf{1 8 5 . 6 0 6}$ & $\mathbf{2 1 , 1}$ \\
\hline
\end{tabular}

Fonte: MAPA (2012).

Por se tratarem de projeções, algumas incertezas podem ocorrer ao longo dos anos, como recessão mundial, aumento do protecionismo nos países 
importadores ou mudanças severas no clima mundial. Porém, diante o cenário atual, a demanda mundial de alimentos tem sido crescente, seja para consumo humano, ração animal, indústrias diversas, ou para combustível, abrindo mais espaço para a soja, que é o principal substituto de diversos grãos, devido à sua versatilidade. 


\section{Corredores de exportação}

\subsection{A integração logística no escoamento da soja}

O transporte intermodal é entendido por ser o transporte que leva a carga da sua origem ao seu destino usando mais de um modal de transporte, sendo em todas as etapas a troca de informações um fator muito importante a ser considerado. Há a emissão de documentos de transportes independentes, um de cada transportador, cada um assumindo a responsabilidade pelo seu transporte.

Em 1993, European Conference of Ministers of Transport, definiu o conceito de intermodalidade:

"O movimento de bens em uma única unidade de carregamento, que usa sucessivos modais de transporte sem manuseio dos bens na mudança de um modal para outro".

$\mathrm{Na}$ multimodalidade, existe a emissão de apenas um documento de transporte, emitido pelo OTM - Operador de Transporte Multimodal, de ponta a ponta. Quanto à responsabilidade da carga ela é do OTM, do ponto de partida até a entrega final ao destinatário. O transporte é realizado por mais de um modal, caracterizando um serviço porta-a-porta com uma série de operações de transbordo realizadas de forma eficiente. Esta combinação é feita de forma a se obter vantagens que resultem em um serviço atrativo, quando comparado com um serviço unimodal.

Para a integração logística no escoamento da soja devem ser consideradas as dificuldades de se transferir mercadorias entre diferentes veículos de diferentes modais, como por exemplo: entre ferrovias e navios. Neste caso, a multimodalidade pode ser encarada como uma ferramenta, ou até mesmo uma oportunidade. A multimodalidade pode oferecer condição para a redução dos custos de transferência e melhoria dos serviços.

De acordo com Goebel (2002), a logística possui um papel fundamental no desempenho das exportações brasileiras. É essencial tornar a logística eficiente para tornar o produto brasileiro competitivo no mercado externo. $\mathrm{O}$ autor ainda afirma:

"As vantagens comparativas na produção doméstica precisam ser preservadas na entrega do produto na fronteira nacional. Ao mesmo tempo, devem ser consideradas as questões logísticas que 
influenciam a entrega do produto ao consumidor final. Sob esse aspecto, questões logísticas que facilitem os canais de distribuição nos mercados consumidores são igualmente relevantes." (Goebel, 2002).

Para a exportação da soja brasileira, é importante destacar que os gargalos logísticos não se encontram somente no modal rodoviário, que possui maior representatividade na matriz de transporte do país. A baixa participação dos modais ferroviário e hidroviário, a falta de infraestrutura nos portos brasileiros e a falta de terminais para integração entre os modais são um agravante para a integração logística.

Ojima (2006) destaca que, apesar da expansão das áreas agrícolas, o setor de transportes não acompanhou este crescimento. A produção de grãos depende de um sistema logístico eficiente para que seu escoamento seja adequado. O autor aponta que, para o aumento da competitividade dos produtos, é necessária a integração dos corredores de transporte multimodais e a união dos centros produtores com os centros consumidores e o mercado internacional.

\subsection{Principais corredores de escoamento}

Corredores de escoamento são definidos por um conjunto integrado de transporte e armazenamento usados para escoar produções de alto volume e grandes concentrações. Com isto, é possível obter custos reduzidos para o escoamento da produção a partir da escolha adequada de vias, veículos, redes de armazéns, terminais e instalações portuárias.

Segundo Lício e Corbucci (1996), é possível citar alguns destes corredores multimodais no Brasil, sendo estes os principais até meados do ano 2000:

- Corredor Centro-Norte: envolvendo cerca de 80 milhões de hectares distribuídos por todo o Estado do Tocantins, sul do Maranhão (região de Balsas) e Piauí, sudeste do Pará, leste do Mato Grosso e Nordeste de Goiás. Os principais modais de transporte envolvidos neste corredor são: Rios Araguaia, das Mortes (afluente do primeiro) e Tocantins; Rodovia BR-010 (Belém-Brasília); Ferrovias Norte-Sul e Carajás; Portos de Ponta da Madeira e de Itaqui-MA. Projetaram-se investimentos da ordem de US\$ 209 milhões para este corredor, envolvendo o ajuste dos rios e a expansão da Ferrovia Norte-Sul de Imperatriz-MA para Estreito-MA. 
- Corredor Centro-Leste: abrange os arredores do Distrito Federal, o noroeste de Minas Gerais e a região de Belo Horizonte. Caracteriza-se principalmente pela Estrada de Ferro Vitória-Minas (entre o Porto de Tubarão e Belo Horizonte), da Companhia Vale do Rio Doce, e pela Ferrovia entre Belo Horizonte e Pirapora-MG. Para este corredor, foram projetados investimentos ao redor de US\$ 292 milhões, envolvendo a implantação da ferrovia entre Pirapora e Unaí.

- Corredor Noroeste: abarca a área de atuação do Grupo Maggi, com o uso dos Rios Madeira e Amazonas e as rodovias BR-364 (entre Porto Velho-RO e o noroeste do Mato Grosso). Envolve também a rodovia que interliga Cuiabá-MT a Santarém-PA.

- Corredor Nordeste: envolve principalmente os Estados de Minas Gerais (porção norte), Bahia e Pernambuco, tendo ampla influência sobre toda a Região Nordeste do país. A sua base é o Rio São Francisco e afluentes (especialmente a extensão navegável de Pirapora-MG a Petrolina/Juazeiro-BA), a malha rodoviária a partir de Pirapora e a partir de Petrolina/Juazeiro até Recife e Fortaleza. Este corredor pode também interligar-se ao Centro-Leste via Pirapora. Projetou-se investimentos de cerca de US\$ 774 milhões, envolvendo acertos no complexo do Rio São Francisco (US\$ 7,5 milhões) e o restante na construção e recuperação de trechos rodoviários.

- Corredor Cuiabá-Santarém: envolve a rodovia Cuiabá-Santarém (BR-163) e os Rios Teles Pires-Tapajós (para os quais era preciso ser realizados investimentos em eclusas), com amplo potencial de escoamento de regiões produtores aos arredores de Cuiabá e ao norte do Mato Grosso.

- Corredor Tietê-Paraná: abrange o complexo hidroviário dos Rios Tietê, Paraná e Paraguai, com potencial de integração regional entre os Estados de São Paulo, Paraná, Mato Grosso do Sul, sul de Goiás e Triângulo Mineiro.

- Corredor Paraná-Paraguai: também chamado de "Hidrovia do Mercosul", apresenta amplo potencial de interligar regiões produtoras do Brasil, Argentina e Paraguai, tendo como principais eixos as cidades de Corumbá-MS e Buenos Aires, já havendo operações também a partir de Cáceres-MT. A empresa ACBL Hidrovias S/A, formada por capitais norteamericanos e argentinos, explora este corredor desde de 1996. Obteve investimentos da ordem de US\$ 65 milhões e planejou investir mais US\$190 milhões até 2001. 


\subsubsection{O escoamento da soja}

A região Centro-Oeste atualmente concentra a maior parte da produção de commodities. Com a transferência da produção de grãos da Região Sul para o Centro-Oeste brasileiro, observou-se a utilização, principalmente, dos nove corredores citados na Tabela 6, para o escoamento da soja.

Tabela 6 - Principais corredores de escoamento e exportação de soja.

\begin{tabular}{|c|c|c|c|c|c|c|}
\hline \multirow[b]{2}{*}{$\begin{array}{l}\text { Macro-Regiōes } \\
\text { Produtoras }\end{array}$} & \multicolumn{6}{|c|}{ Corredores } \\
\hline & $\mathrm{N}^{\circ}$ & Porto & $\begin{array}{c}\text { Região de } \\
\text { Procedência }\end{array}$ & Modais de Acesso & $\begin{array}{c}1,000 \mathrm{t} \\
\text { Exportada } \\
2007 \\
\end{array}$ & $\begin{array}{l}\text { Ferrovias: } \\
\text { Utilizadas }\end{array}$ \\
\hline \multirow{2}{*}{$\begin{array}{l}\text { CERRADO } \\
\text { Centro-Oeste } \\
\text { (CO) }\end{array}$} & 1 & $\begin{array}{l}\text { Itacoatiara } \\
\text { (AM) }\end{array}$ & $\mathrm{co}$ & \begin{tabular}{|l|} 
Rodovia - Até Porto \\
Velho \\
Hidrovia - Porto Velho \\
a Itacoatiara
\end{tabular} & 2.053 & \\
\hline & 2 & Santarém $(\mathrm{PA})$ & $\mathrm{co}$ & Rodovia & 836 & \\
\hline \multirow{3}{*}{$\begin{array}{l}\text { Partes do } \\
\text { Sudeste (SE), } \\
\text { Nordeste (NE) e } \\
\text { Norte (N) } \\
\text { MG / SP / BA, / } \\
\text { PI / MA / TO }\end{array}$} & 3 & $\begin{array}{l}\text { Ittaquí } \\
\text { (MA) }\end{array}$ & $C O / \mathrm{NE} / \mathrm{N}$ & \begin{tabular}{|l|} 
Rodovia \\
Rodovia / Ferrovia \\
Hidrovia Rio das \\
Mortes - Araguaia / \\
Rodovia / Ferrovia - \\
Paralizada
\end{tabular} & 1.570 & $\begin{array}{c}\text { Norte Sul } \\
\text { EFC }\end{array}$ \\
\hline & \begin{tabular}{|l|}
4 \\
\end{tabular} & Ilhéus (BA) & SE / NE & Rodovia & 1.280 & \\
\hline & 5 & $\begin{array}{l}\text { Vitónia } \\
\text { (ES) }\end{array}$ & $\mathrm{CO} / \mathrm{SE}$ & Rodovia / Ferrovia & 3.427 & $\begin{array}{l}\text { FCA } \\
\text { EFVM }\end{array}$ \\
\hline \multirow[t]{3}{*}{$\begin{array}{l}\text { CERRADO } \\
\text { E } \\
\text { SUL }\end{array}$} & 6 & $\begin{array}{l}\text { Santos } \\
\text { (SP) }\end{array}$ & CO/SE / S & $\begin{array}{l}\text { Rodovia } \\
\text { Rodovia / Hidrovia } \\
\text { Tieté - Paraná / } \\
\text { Rodovia } \\
\text { Rodovia / Ferrovia } \\
\text { Rodovia / Ferrovia / } \\
\text { Rodovia }\end{array}$ & 7.177 & $\begin{array}{l}\text { FCA } \\
\text { ALL } \\
\text { MRS }\end{array}$ \\
\hline & 7 & $\begin{array}{l}\text { Paranaguá } \\
\text { (PR) }\end{array}$ & $\mathrm{cols}$ & \begin{tabular}{|l|} 
Rodovia \\
Rodovia / Ferrovia \\
\end{tabular} & 10.805 & $\begin{array}{l}\text { Ferropar } \\
\text { ALL }\end{array}$ \\
\hline & 8 & $\begin{array}{c}\text { São Francisco } \\
\text { do Sul (PR) } \\
\end{array}$ & $\mathrm{cols}$ & $\begin{array}{l}\text { Rodovia } \\
\text { Rodovia / Ferrovia }\end{array}$ & 2.703 & ALL \\
\hline $\begin{array}{c}\text { SUL } \\
\text { PR/SC/RS }\end{array}$ & 9 & $\begin{array}{l}\text { Rio Grande } \\
\text { (PR) }\end{array}$ & S & $\begin{array}{l}\text { Rodovia } \\
\text { Rodovia / Ferrovia }\end{array}$ & 7.856 & ALL \\
\hline
\end{tabular}

Fonte: ANUT (2008).

Os três principais portos utilizados por estes corredores de exportação com maior quantidade exportada no ano de 2007 são Paranaguá, Santos e Rio Grande sendo que, do total, os acessos ferroviários atendem somente os portos de Rio Grande, São Francisco do Sul, Paranaguá, Santos, Vitória e Itaquí.

A partir da Figura 9 é possível visualizar no mapa a malha dos modais de transporte utilizados para o escoamento da soja e os principais portos envolvidos com destino ao mercado interno e externo. 


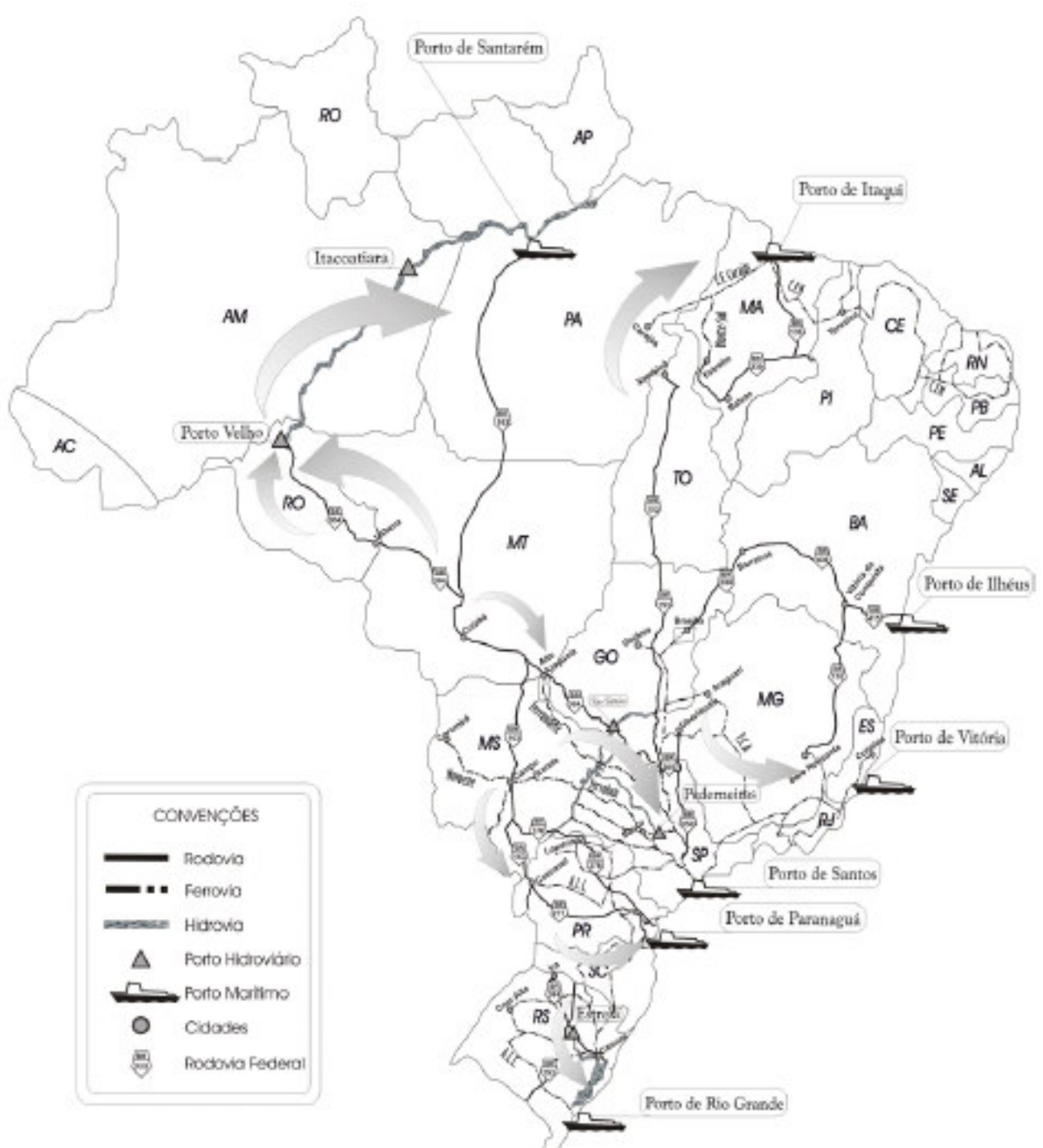

Figura 9 - Principais Fluxos de Exportação da Soja Brasileira. Fonte: Ojima (2006).

A movimentação da soja dos produtores para o mercado externo é realizada por diferentes tipos de modais e rotas, como descritos a seguir, de acordo com Ojima (2006):

- Região Centro-Oeste: de acordo com a Figura 9, é possível observar que a produção desta região é exportada através dos portos de Santos, Paranaguá e Vitória. Os centros produtores se encontram muito distantes destes portos, por este motivo, o transporte é um fator muito importante para a competitividade dos produtos. A utilização dos portos Santos, Paranaguá e Vitória, muitas vezes são compartilhadas com a produção da Região Sul. Isto causa congestionamentos nos portos, com demora para embarque e em seus acessos, gerando filas de alguns quilômetros de extensão. Isto mostra um déficit nos acessos aos portos e em sua 
capacidade portuária. Diante de tais problemas, os produtores agrícolas estão buscando alternativas, como o escoamento da soja pelas regiões Norte e Nordeste pelos portos de Itacoatiara, Santarém e São Luís, principalmente pela chegada da Ferrovia Norte-Sul a São Luís, que leva uma parte da produção de grãos do Centro-Oeste para ser exportada via Maranhão. As rodovias BR-163 e BR-364 são duas principais rodovias que ligam as áreas produtoras de Mato Grosso ao porto de Paranaguá (PR) e as do Mato Grosso e Mato Grosso do Sul a Rondônia e também ao porto de Santos (SP), respectivamente. Além disso, o corredor TietêParaná possibilita trazer a soja em grão das regiões produtoras do Centro-Oeste, para áreas próximas dos maiores centros consumidores do país, com destino aos terminais hidroviários de Pederneiras e Panorama, possibilitando seguir para o porto de Santos.

- Região Sul: esta região possui as áreas tradicionais de produção de grãos, tendo rodovias e ferrovias já implantadas. A produção desta região está próxima aos portos de Paranaguá, Santos e Rio Grande. A principal ferrovia de acesso aos portos é a ALL, sendo uma das principais rotas de escoamento da soja do norte do estado de Paraná ao porto de Paranaguá. Além disso, para o porto de Santos, o acesso é feito por meio de rodovia-ferrovia, utilizando a ALL, com soja vinda principalmente do estado de Mato Grosso do Sul. Para o porto de Paranaguá, as rodovias utilizadas são BR-376 e BR-227. O estado do Rio Grande do Sul acessa as rodovias BR-386 e BR-153 para o porto de Rio Grande. Porém, os portos enfrentam os mesmos problemas de congestionamentos que na região CentroOeste no período de safra, sobretudo Santos e Paranaguá.

-Região Sudeste: existem diversas rodovias disponíveis para esta região, sendo o estado de Minas Gerais ligado pela BR-050 a São Paulo, e depois segue por ferrovia ou rodovia até o porto de Santos. É possível utilizar a hidrovia TietêParaná com grãos oriundos da região Centro-Oeste até o terminal de Pederneiras, seguindo para o porto de Santos. Também é possível utilizar a ferrovia FCA (Ferrovia Centro-Atlântica) e a Ferrovia Vitória-Minas, para ser exportada pelo porto de Vitória.

- Região Norte: as produções desta região, principalmente o estado de Rondônia, utilizam as rodovias BR-364, as hidrovias Madeira-Amazonas com soja vinda do estado de Mato Grosso até o terminal de Itacoatiara. As rodovias BR-163 e BR-153, junto com as hidrovias Teles-Pires Tapajós e Araguaia- 
Tocantins também são utilizadas para serem exportadas pelos portos de Itacoatiara, Santarém e Itaqui.

- Região Nordeste: o escoamento nesta região acontece principalmente por meio de rodovias, ferrovias e em um trecho curto por meio do rio São Francisco seguindo para o porto de Ilhéus. A produção da Bahia pode ser escoada pelas rodovias BR-430 e BR-415, em seguida para o porto de Ilhéus. Para os estados de Piauí e Maranhão é utilizada a BR-230 até o Estreito, depois segue pela ferrovia Norte-Sul que é ligada à estrada de Ferro Carajás, seguindo para o porto de Itaqui.

O acesso aos corredores de exportação é crítico para determinar a competitividade da indústria de esmagamento. Para obter tal competitividade, é importante que esta alternativa dependa ainda de uma ligação mais eficiente com o porto, que não necessite de um número elevado de transbordos. 


\section{Análise dos portos para atender o comércio exterior}

Nas exportações brasileiras, a via marítima é a mais utilizada quando comparada com outros tipos de modais. As rodovias e ferrovias são mais utilizadas para conectar países do Mercosul, enquanto a via marítima é mais usada na exportação de granéis sólidos. Por ter o frete mais elevado, a via aérea acaba sendo muito pouco empregada, sendo inviável para grande parte das cargas.

Pelo fato de a movimentação de carga nos portos estar em constante crescimento, estes passaram a ter um papel fundamental na trajetória da carga. Com a movimentação das cargas, os portos assumem função estratégica na cadeia, passando a ser um canal de comercialização. Neste contexto, se torna cada vez mais importante a definição e implantação de projetos de melhorias nos portos brasileiros para que os produtos nacionais adquiram competitividade no mercado internacional.

De acordo com Goebel (2002), pelo fato dos portos serem parte do início e do final do transporte marítimo e transportarem o maior volume de carga ao longo da cadeia, estes apresentam oportunidade de alcançar melhorias de escala em atividades técnicas, comerciais e industriais adicionais quando se faz preciso. Além disso, por assumirem múltiplas funções, que não se baseiam somente em movimentar cargas, há a oportunidade de transformar os portos em plataformas logísticas. Goebel ainda destaca os seguintes critérios que os portos se desenvolvem:

- a política, a estratégia e a atitude de desenvolvimento portuário;

- o escopo e a extensão das atividades portuárias, particularmente quanto aos aspectos associados à área de informação; e

- a integração da organização e das atividades portuárias.

Na Figura 10, é possível observar os principais aspectos associados às três gerações de evolução dos portos. Os portos da $1^{\mathrm{a}}$ geração geralmente possuem seus serviços simples e com baixo valor agregado. 


\begin{tabular}{|c|c|c|c|}
\hline & 13 Geraçăo & 2: Geraçio & 3e Geraçio \\
\hline $\begin{array}{l}\text { Periodo de } \\
\text { Desenvalvimento }\end{array}$ & - Antes dos Anos 60 & - Após os Anos 60 & - Após os Años 80 \\
\hline Principais Cargas & - Carga Geral e Graneis & - Carga Geral e Granéis & $\begin{array}{l}\text { - Cargas Conteinerizadas, } \\
\text { Unitizadas e Granéis }\end{array}$ \\
\hline $\begin{array}{l}\text { Atitude e Estratígia } \\
\text { de Desenvolvimento } \\
\text { do Porto }\end{array}$ & $\begin{array}{l}\text { - Conservadora } \\
\text { - Ponto de Interace dos } \\
\text { Modos de Transporte }\end{array}$ & $\begin{array}{l}\text { - Expansionista } \\
\text { - Centro de Transporte, } \\
\text { Comercial é Industrial }\end{array}$ & $\begin{array}{l}\text { - Orientado para o } \\
\text { Comércio } \\
\text { - Centro de Transporte } \\
\text { Integrado e Plataforma } \\
\text { Logística para o Comér- } \\
\text { cio Internacional }\end{array}$ \\
\hline Atividades & $\begin{array}{l}\text { - Carga, Descarga, Ama- } \\
\text { zenagem, Serviço de } \\
\text { Navegaçá } \\
\text { - Cais para Atracaçálo das } \\
\text { Embarcagós } \\
\text { - Abastecimento dos } \\
\text { Navios }\end{array}$ & $\begin{array}{l}\text { - Carga, Descarga, Arma- } \\
\text { zenagen, Serviço de } \\
\text { Navegaçáo } \\
\text { - Cas para Atracaço das } \\
\text { Embarcaçós } \\
\text { - Abastecimento dos } \\
\text { Navios } \\
\text { - Transfomaçá da } \\
\text { Carga, Serviços Comer- } \\
\text { ciaise Industrais Vin- } \\
\text { culados aos Navios }\end{array}$ & 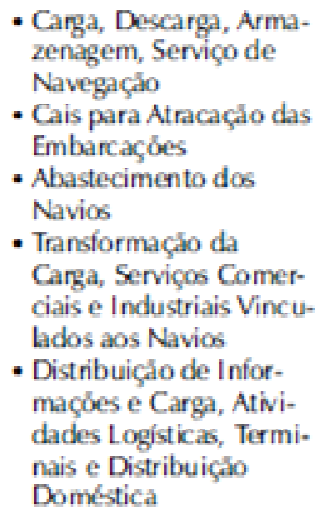 \\
\hline $\begin{array}{l}\text { Caracteristicas dà } \\
\text { Organizaḉó }\end{array}$ & $\begin{array}{l}\text { - Atividades Independen- } \\
\text { tes dentro do Fortó } \\
\text { - Relacio Informal entre } \\
\text { o Porto é ó seus Usuá- } \\
\text { rios }\end{array}$ & $\begin{array}{l}\text { - Relaçdo Próxima entre } \\
\text { Porto e Usuárío } \\
\text { - Relaços Pouco Integra- } \\
\text { das être as Atividades } \\
\text { Realizadas no Porto } \\
\text { - Relacionamento Próxi- } \\
\text { mo com a Municipali- } \\
\text { dade }\end{array}$ & $\begin{array}{l}\text { - Comunidade Portuárí } \\
\text { Integrada } \\
\text { - Integracio do Porto } \\
\text { com a Rede de Comér- } \\
\text { cio e Transporte } \\
\text { - Relaço Próxima entre } \\
\text { o Porto è Municipali- } \\
\text { dade } \\
\text { - Organizaço Portuária } \\
\text { Ampliada }\end{array}$ \\
\hline $\begin{array}{l}\text { Canacteristicas da } \\
\text { Produçóo de } \\
\text { Serviços }\end{array}$ & $\begin{array}{l}\text { - Concentrada no Fluxo } \\
\text { de Carga } \\
\text { - Servigos Relativamente } \\
\text { Simples } \\
\text { - Babo Valor Agregado }\end{array}$ & $\begin{array}{l}\text { - Fluxo de Carga } \\
\text { - Transfomactá da Carga } \\
\text { - Servigos Integrados } \\
\text { - Valor Agregado Médio }\end{array}$ & 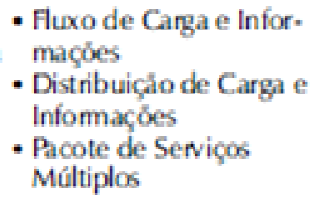 \\
\hline Fatores Decisinos & - Trabalho e Capital & - Capital & - Teconologia e Know-How \\
\hline
\end{tabular}

Para $2^{\mathrm{a}}$ geração, os portos apresentam estratégia expansionista e exercem mais atividades. As funções dos portos marítimos são vistas como centros de serviço de transporte, industrial e comercial, com atividades mais integradas com o aumento de volume e da rápida rotatividade da carga através de todo o porto. Nos portos de $3^{a}$ geração, a carga conteinerizada é incluída e o fluxo de carga e informações é amplo de maneira a desenvolver tecnologia e know-how. Os portos passam a ser vistos como uma complexa rede de distribuição e produção internacional e, com isso, participam mais ativamente do comércio internacional. 
A partir da Figura 10, e análise dos principais portos brasileiros, é possível constatar que os portos brasileiros se encontram entre a $1^{\mathrm{a}}$ e a $2^{\mathrm{a}}$ geração, com nítidas oportunidades de melhorias e investimentos.

\subsection{Evolução da demanda por serviços nos portos}

De acordo com dados da Balança Comercial Brasileira, em 2011, o comércio exterior brasileiro registrou na soma das exportações e importações o total de US\$ 482,3 bilhões, com aumento de 25,7\% sobre 2010, quando o resultado foi de US\$ 383,7 bilhões. As exportações encerraram 2011 com valor de US\$ 256,0 bilhões e as importações de US\$ 226,2 bilhões, sendo os dois resultados igualmente recordes. Em relação a 2010, as exportações apresentaram crescimento de $26,8 \%$ e as importações de $24,5 \%$.

O Brasil aparece como um exportador em expansão, ocupando, em 2010, o $22^{\circ}$ lugar no ranking dos países exportadores, com o primeiro lugar sendo ocupado pela China, seguido de Estados Unidos e Alemanha. Estes três países

representam, respectivamente, $10,4 \%, 8,4 \%$ e 8,3\% de participação nas exportações. O Brasil representa 1,3\% na participação das exportações, ficando a frente da Malásia e antes da Austrália (Balança Comercial Brasileira, 2011).

Em 2011, destacam-se as exportações para a Ásia, que aumentaram 36,3\%, sendo a China o principal destino com 17,3\% de participação nas exportações brasileiras, o que representou U\$44,3 bilhões em 2011, com aumento de 43,9\% quando comparado com 2010. Segundo a Associação Brasileira dos Terminais Portuários (ABTP), mais de 70\% das exportações brasileiras são de commodities. A recuperação de preços de commodities minerais e agrícolas fez aumentar a participação desses produtos nas exportações do país, uma tendência que deverá manter-se no futuro próximo. (Balança Comercial Brasileira, 2011).

Em 2011, o Brasil alcançou o valor de U\$226,2 bilhões em suas importações, com um aumento de 24,5\% em comparação com 2010. O maior importador do mundo no ano anterior foi representado pelos Estados Unidos, seguido pela China e Alemanha. O Brasil, em 2010, ocupou o $20^{\circ}$ lugar no ranking dos principais importadores mundiais, com 1,2\% de participação, sendo a mesma participação que os países: Turquia e Tailândia. (Balança Comercial Brasileira, 2011). 
A movimentação de cargas no setor portuário nacional, que considera Portos Públicos e Terminais Privativos, no ano 2011, segundo ABTP atingiu 886 milhões de toneladas, com um aumento geral de $6,4 \%$ em relação a 2010 . O principal responsável por este resultado foi o desempenho das commodities brasileiras. Observou-se, também, que a Carga Geral foi o segmento que apresentou os maiores índices de crescimento anual nos últimos dez anos - 10\%, contra os $6 \%$ dos Granéis Sólidos e Líquidos. Desde 2001 a movimentação de cargas no sistema portuário brasileiro cresceu $73 \%$. Este crescimento se deve ao aumento das exportações e às cotações nos mercados internacionais das commodities, conforme evolução observada no Gráfico 1, a seguir.

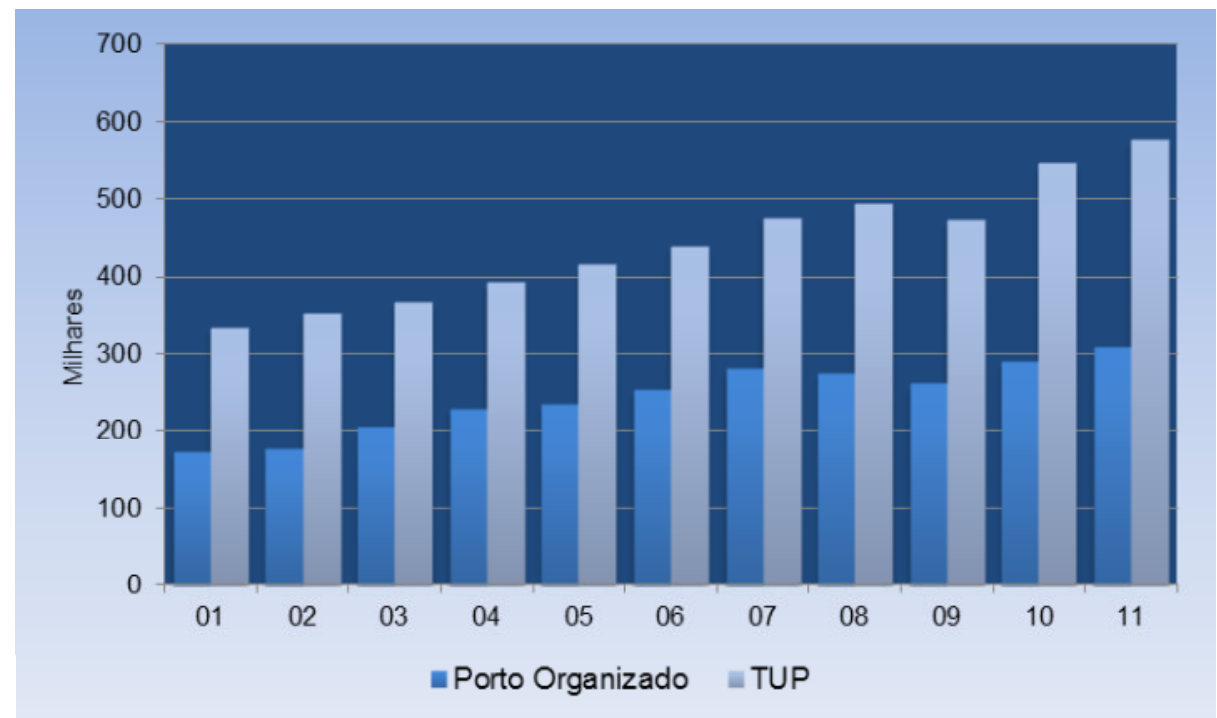

Gráfico 1 - Movimentação de Cargas nos Portos Públicos e TUP (2001 a 2011). Fonte: ABTP (2011).

Em relação à movimentação dos principais tipos de cargas, segundo ABTP, os granéis sólidos representados por minérios e cereais e seus derivados, alcançaram $61 \%$ do total da tonelagem movimentada pelo Sistema Portuário Nacional com cerca de 543 milhões de toneladas. Os granéis líquidos, representados pelo petróleo e seus derivados e etanol, responderam por 212 milhões de toneladas, correspondendo a aproximadamente $24 \%$ do total movimentado em 2011. A carga geral, que inclui contêineres, movimentou cerca de 131 milhões de toneladas, ou 15\% da movimentação total.

Segundo os dados da ANTAQ, em 2010, a movimentação total retomou a taxa de crescimento registrada desde 2000, já que em 2009 com a crise mundial houve redução desta movimentação. Assim, seguindo esta evolução, há 
indicadores de que nos próximos três a quatro anos, o sistema portuário venha a ultrapassar o patamar de um bilhão de toneladas movimentadas. Com isso, investimentos no setor de transportes são de extrema importância para que seja possível sustentar o aumento da capacidade prevista, incluindo investimentos portuários, tanto privados quanto públicos, na ampliação e modernização dos terminais e pátios portuários.

Em relação ao tipo de acondicionamento das cargas, ressalta-se o crescimento da movimentação de contêineres. A movimentação brasileira de contêineres atingiu 7,9 milhões de TEUs em 2011, com aumento de $16 \%$ em relação a 2010. Com exceção do ano 2009, a movimentação de contêineres apresenta um crescimento anual médio em torno de 11\% (ABTP, 2011).

Ainda de acordo com ABTP, a distribuição regional da movimentação portuária por região brasileira, reflete as principais cadeias logísticas de movimentação de granéis, e destacam uma concentração do comércio de produtos de maior valor agregado nas Regiões Sudeste e Sul. Conforme mostra a Tabela 7, a região Norte apresentou o maior crescimento no período de 2010 - 2011, com um total de 81,5 milhões de toneladas (12\%) sobre o total de 2010. Por ordem, em seguida as regiões Nordeste, Sul e Sudeste. O Sudeste é a região que concentra mais da metade das cargas portuárias brasileiras. Em relação a 2010, houve um acréscimo de 465 mil TEUs, com principal crescimento para o porto do Rio de Janeiro (32\%), Itaguaí (47\%) e Santos (9\%). 
Tabela 7 - Movimentação Portuária por Natureza e Região - 2010/2011.

\begin{tabular}{|c|c|c|c|c|}
\hline & & & \multicolumn{2}{|c|}{ Valores em milhões de toneladas } \\
\hline Região & Natureza & 2010 & 2011 & $\%$ \\
\hline \multirow{5}{*}{ Norte } & Total & 72.918 & 81.534 & $12 \%$ \\
\hline & Carga Geral (t) & 13.181 & 13.471 & $2 \%$ \\
\hline & Sólido (t) & 47.240 & 53.402 & $13 \%$ \\
\hline & Liquido $(\mathrm{t})$ & 12.496 & 14.661 & $17 \%$ \\
\hline & TEU $(u)$ & 475.867 & 550.057 & $16 \%$ \\
\hline \multirow{5}{*}{ Nordeste } & Total & 185.019 & 199.633 & $8 \%$ \\
\hline & Carga Geral (t) & 15.150 & 16.042 & $6 \%$ \\
\hline & Sólido (t) & 125.809 & 137.548 & $9 \%$ \\
\hline & Líquido $(\mathrm{t})$ & 44.058 & 46.042 & $5 \%$ \\
\hline & TEU $(u)$ & 804.606 & 936.206 & $16 \%$ \\
\hline \multirow{5}{*}{ Sudeste } & Total & 458.329 & 477.650 & $4 \%$ \\
\hline & Carga Geral (t) & 63.231 & 69.819 & $10 \%$ \\
\hline & Sólido (t) & 277.111 & 289.433 & $4 \%$ \\
\hline & Liquido (t) & 117.986 & 118.397 & $0 \%$ \\
\hline & TEU $(u)$ & 3.400 .267 & 3.864 .654 & $14 \%$ \\
\hline \multirow{5}{*}{ Sul } & Total & 111.592 & 121.732 & $9 \%$ \\
\hline & Carga Geral (t) & 27.155 & 31.291 & $15 \%$ \\
\hline & Sólido (t) & 52.182 & 57.240 & $10 \%$ \\
\hline & Líquido (t) & 32.253 & 33.201 & $3 \%$ \\
\hline & TEU (u) & 2.141 .907 & 2.549 .177 & $19 \%$ \\
\hline
\end{tabular}

Fonte: ABTP (2011).

Em pesquisa realizada por Wanke e Hijjar (2009), que avalia as percepções de diferentes segmentos de exportadores sobre a qualidade da infraestrutura logística de exportação, contatou-se que as dificuldades nas operações logísticas, presentes em todas as etapas da cadeia, são mais incidentes nos portos do que nas rodovias e aeroportos. Para os exportadores de cargas a granel, principalmente exportadores de grãos e minério, as maiores dificuldades logísticas para exportação são o escoamento dos produtos e acesso aos portos. Além da falta de investimentos nos últimos anos, também foi ressaltada a piora na burocracia para exportação, acarretando longas filas e espera. Devido ao longo tempo de espera nos portos, e nos acessos a eles, ocorre a falta de coordenação entre o carregamento dos caminhões para os navios. Com isso, há aumento dos gastos, já que o exportador irá pagar demurrage de navios e diária dos caminhões e ainda reduzir a competitividade do produto internacionalmente. 


\subsection{A demanda das regiões por serviços portuários}

Para manter os produtos agroindustriais brasileiros competitivos no mercado, é fundamental que o escoamento dos produtos para exportação seja feita de forma eficiente. Para isto, é necessário que os portos sejam capazes de absorver a demanda e operar com custos reduzidos. Além disso, alternativas de transportes com fretes reduzidos, tanto marítimos como terrestres, são decisivos para a competitividade desses produtos no mercado internacional.

Conforme mencionado anteriormente, os estados produtores de soja no Brasil e suas participações na produção da soja estão representados na Figura 11. Estes estados exportaram por via marítima, em 2011, cerca de 309 milhões de toneladas de todos os produtos produzidos nestas regiões. As Tabelas 8 e 9 sumarizam as quantidades e valores totais das mercadorias exportadas, por via marítima, pelos estados produtores de soja no período de 2009 a 2011.

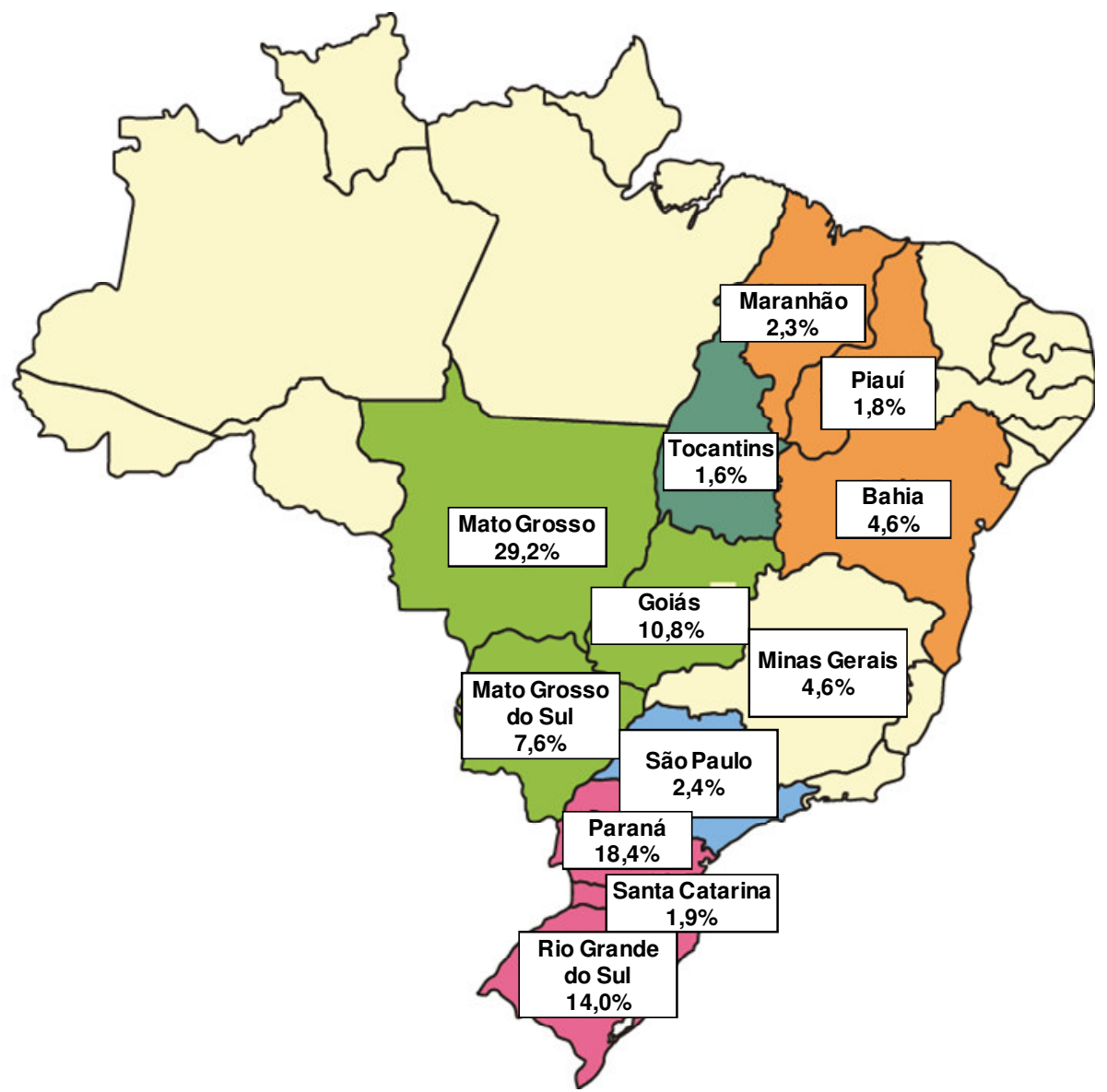

Figura 11 - Estados produtores de soja em grãos e suas participações. Fonte: Adaptado de MAPA (2012). 
Tabela 8 - Exportações dos estados produtores de soja, por via marítima, em toneladas.

\begin{tabular}{|l|r|r|r|}
\hline \multicolumn{4}{|c|}{ Quantidade Via Marítima (Mil t) } \\
\hline UA & \multicolumn{1}{|c|}{2011} & \multicolumn{1}{c|}{$\mathbf{2 0 1 0}$} & \multicolumn{1}{c|}{$\mathbf{2 0 0 9}$} \\
\hline BAHIA & 11.135 & 10.766 & 9.912 \\
\hline MAIAIS & 6.354 & 5.787 & 5.317 \\
\hline MATO GROSSO & 9.562 & 24.299 & 3.377 \\
\hline MATO GROSSO DO SUL & 20.537 & 20.627 & 20.085 \\
\hline MINAS GERAIS & 4.945 & 4.669 & 3.023 \\
\hline PARANÁ & 182.195 & 175.348 & 156.543 \\
\hline PIAUÍ & 20.003 & 19.072 & 16.426 \\
\hline SÃO PAULO & 206 & 159 & 293 \\
\hline SANTA CATARINA & 31.692 & 36.192 & 34.803 \\
\hline RIO GRANDE DO SUL & 4.398 & 3.519 & 3.257 \\
\hline TOCANTINS & 17.326 & 13.907 & 14.232 \\
\hline Total geral & 740 & 700 & 584 \\
\hline
\end{tabular}

Fonte: SECEX/ Sistema Aliceweb.

O valor total das cargas movimentadas foi de aproximadamente 150 bilhões de dólares nestes estados.

Tabela 9 - Exportações dos estados produtores de soja, por via marítima, em valor.

\begin{tabular}{|c|c|c|c|}
\hline \multicolumn{4}{|c|}{ Valor Via Marítima (Milhões US\$) } \\
\hline UF & 2011 & 2010 & 2009 \\
\hline BAHIA & 10.380 & 8.351 & 6.576 \\
\hline GOIAIS & 5.125 & 3.757 & 3.409 \\
\hline MARANHÃO & 2.977 & 2.903 & 1.230 \\
\hline MATO GROSSO & 10.539 & 8.049 & 7.959 \\
\hline MATO GROSSO DO SUL & 3.144 & 2.514 & 1.721 \\
\hline MINAS GERAIS & 37.776 & 28.203 & 17.341 \\
\hline PARANÁ & 14.647 & 11.681 & 9.659 \\
\hline PIAUÍ & 160 & 123 & 159 \\
\hline SÃO PAULO & 42.267 & 36.395 & 29.335 \\
\hline SANTA CATARINA & 7.767 & 6.539 & 5.636 \\
\hline RIO GRANDE DO SUL & 15.472 & 11.993 & 11.886 \\
\hline TOCANTINS & 477 & 343 & 280 \\
\hline Total geral & 150.732 & 120.851 & 95.191 \\
\hline
\end{tabular}

Fonte: SECEX/ Sistema Aliceweb.

Os principais portos utilizados por estes estados para exportação são: Ilhéus, Itaquí, Paranaguá, Rio Grande, Santarém, Santos, São Francisco do Sul e Vitória. 


\subsection{Porto de Santos}

O Porto de Santos é um dos maiores portos brasileiros e é administrado pela Companhia de Docas do Estado de São Paulo. Está localizado no centro do litoral do estado de São Paulo, distando dois quilômetros do oceano Atlântico. Sua área de influência abrange 13 estados brasileiros. Cinco deles compõem sua hinterlândia primária: São Paulo, Goiás, Mato Grosso, Mato Grosso do Sul e Minas Gerais. Outros cinco estados fazem parte de sua hinterlândia secundária: Rio de Janeiro, Paraná, Espírito Santo, Bahia e Rio Grande do Sul. Integram a hinterlândia terciária do Porto de Santos: Tocantins, Rondônia e Distrito Federal. Cerca de $90 \%$ da base industrial do Estado de São Paulo está localizada a menos de 200 quilômetros do Porto de Santos (CODESP, 2011).

O Porto de Santos, no período de 1994 a 2004, atingiu o dobro de sua movimentação em dez anos. No ano de 2011, o movimento de cargas ultrapassou 97,2 milhões de toneladas, com aumento de $1,2 \%$ sobre a movimentação registrada em 2010, com 96,1 milhões de toneladas e consolidando o crescimento do movimento no complexo portuário santista. De acordo com a CODESP, o porto possui o desafio e meta de em 2025 alcançar 230 milhões de toneladas por ano. Ainda de acordo com a CODESP, o porto de Santos ocupou em 2008 o $51^{\circ}$ lugar no ranking dos portos líderes do mundo (81 milhões de toneladas). Sendo o primeiro lugar ocupado pelo porto de Xangai com 582 milhões de toneladas. Quando comparado com o porto de Xangai, observa-se que há oportunidades de melhorias para o porto, que envolvem em grande parte a questão da infraestrutura, já que as escalas estão mudando, demandando maiores volumes, controle, demanda e exigindo uma lógica de distribuição muito mais complexa e sofisticada.

Segundo dados da CODESP (2010), o Porto de Santos possui área total de 7.765.100 $\mathrm{m}^{2}$, sendo $3.665 .800 \mathrm{~m}^{2}$ na margem direita, nos municípios de Guarujá e Cubatão, e 4.099.300 $\mathrm{m}^{2}$ na margem esquerda, no município de Santos. Possui $13 \mathrm{~km}$ de extensão de cais, com profundidades de projeto variando entre 7,3 e 14 metros, que comportam 62 berços de atracação. Do total de sua extensão, 11,6 km são cais de uso público sob jurisdição da CODESP, com 51 berços e 1,4 km pertencem à iniciativa privada com 11 berços de atracação dos Terminais

Privativos administrados pelas empresas: Dow Química (produtos químicos), 
Cutrale (suco cítrico granel a e farelo de polpa cítrica), Cargill (soja em grão, farelo de soja e açúcar a granel), Fosfértil (fertilizantes) e Usiminas (granéis sólidos e carga geral).

Segundo CODESP (2010), o Porto de Santos possui terminais especializados para operação de carga geral acondicionada em contêiner, granéis sólidos e líquidos. Possui trechos com instalações especializadas para movimentação dessas cargas e de carga geral não acondicionada em contêiner. Os principais produtos movimentados no porto de Santos são: granel sólido (açúcar, milho, soja, carvão, enxofre, trigo, sal e polpa cítrica), granel líquido (óleo combustível, álcool, óleo diesel, gasolina, GLP, óleo vegetal, suco de laranja), carga geral (açúcar, celulose, papel, alumínio cargas especiais e conteinerizadas) e veículos. Para armazenamento de granéis líquidos conta com uma capacidade estática de, aproximadamente, $700 \mathrm{mil} \mathrm{m}^{3}$; e para granéis sólidos, instalações para acondicionar mais de 2,5 milhões de toneladas.

Nos terminais especializados localizados nas duas margens do estuário verificam-se a seguinte disponibilização de berços: 1 para veículos; 14 para contêineres; 5 para fertilizantes/adubos; 6 para produtos químicos; 2 para cítricos; 8 para granéis sólidos de origem vegetal; 1 para sal; 2 para passageiros; 1 para produtos de origem florestal; 1 para derivados de petróleo, 4 para trigo; 5 para produtos siderúrgicos; 10 para carga geral e 2 de multiuso (suco cítrico a granel, roll-on/roll-off e contêiner).

Sua estrutura para armazenagem inclui:

- 75 armazéns, com área de $499.701 \mathrm{~m}^{2}$;

- 50 pátios de estocagem, somando $981.603 \mathrm{~m}^{2}$;

- Galpões para inflamáveis, com 4.817 m²;

- 200 km de linhas férreas internas;

- Variação de maré de 1,2 metros;

- 10 áreas para granéis líquidos, totalizando 431.478 m², dotadas com 255 tanques, com capacidade para $585.111 \mathrm{~m}^{3}$ e dutos com $55 \mathrm{~km}$ de extensão.

Os Terminais especializados do Porto de Santos são:

- Terminal para Contêineres - Santos Brasil;

- Terminais para contêineres 34/ 35 e 37 - Grupo Libra; 
- Terminais para Fertilizantes - TEFER;

- TGG - Terminal Graneleiro do Guarujá;

- Terminais para Produtos de Origem Vegetal - Corredor de

Exportação (açúcar a granel, soja em grão e farelos de origem vegetal);

- Terminal para Granéis Líquidos da Alamoa - TEGLA;

- Terminal para Granéis Líquidos da Ilha do Barnabé 16;

- Bulk Terminal - suco cítrico;

- Terminal de Passageiros "Giusfredo Santini” - Concais.

Os terminais com instalações especiais por tipo de carga são:

- Sal - no trecho de cais do armazém 23;

- Granéis sólidos - no cais do Saboó;

- Açúcar a granel - no cais do Armazém 39;

- Trigo - no cais dos armazéns 12- A, 13, sugador do armazém 26 (silo) e armazém 39;

- Suco cítrico a granel - cais do Saboó (Cargill e Citrovita); cais do armazém 29 (Citrosuco) e margem esquerda (Cutrale);

- Tecondi - para operação de carga geral conteinerizada ou não;

- Votorantim Papel e Celulose - para papel e celulose - cais dos armazéns 14 e 15.

A Usina Hidrelétrica de Itatinga é administrada pela Companhia Docas do Estado de São Paulo (CODESP), gerando $15.000 \mathrm{KW}$ de energia, é interligada ao sistema, gerando eletricidade para o Porto de Santos e para o distrito de Vicente de Carvalho, no Guarujá, distantes 30 quilômetros da usina. A usina inaugurada em 1910 foi construída para gerar energia para o Porto de Santos, que necessitava de eletricidade para contar com guindastes cada vez maiores por conta do grande movimento.

Desde 1997, o Porto de Santos opera continuamente 24 horas por dia, em quatro turnos de seis horas, propiciando maior agilidade à movimentação de cargas. A medida foi essencial para atender adequadamente e eficientemente às necessidades de escoamento contínuo de cargas. O suprimento de água é feito pela Sabesp, com hidrômetros instalados ao longo do cais, permitindo fornecimento medido a navios. A malha ferroviária do porto é utilizada para o trânsito de vagões próprios e de ferrovias que atendem o porto. 
Na Figura 12, apresenta-se a entrada do Porto de Santos (ponto B) e o Corredor de Exportação (ponto A).

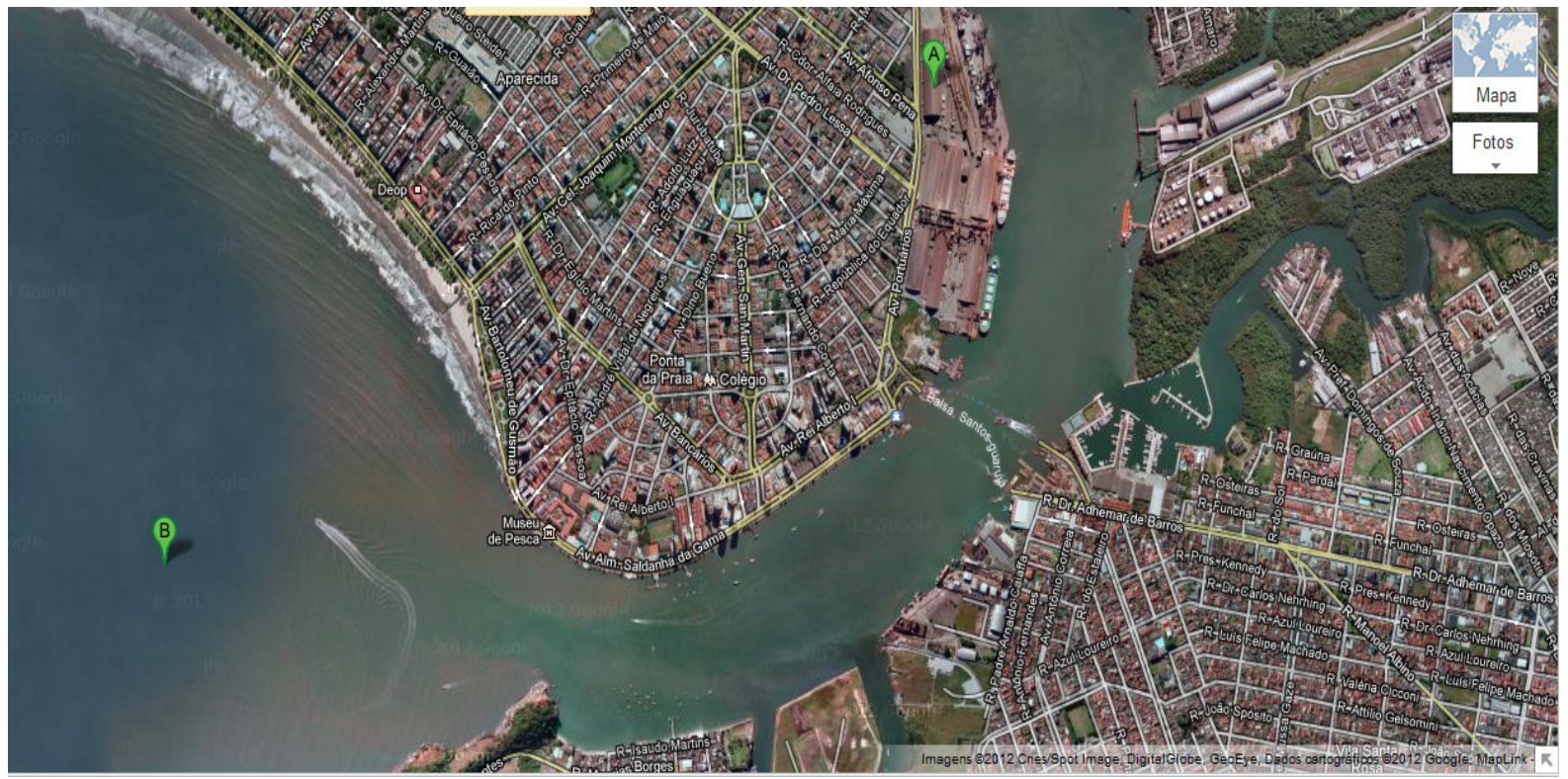

Figura 12 - Porto de Santos.

Fonte: Google Maps (2012).

\subsubsection{O Porto Organizado de Santos}

De acordo com o Regulamento de Exploração do Porto de Santos produzido pelo CAP (Conselho de Autoridade Portuária), são determinadas quais as condições de funcionamento e exploração do porto de Santos, conforme previsto na Lei ${ }^{\circ} 8.630 / 93$ :

Porto Organizado - aquele construído e aparelhado para atender às necessidades da navegação e da movimentação e armazenagem de mercadorias, concedido ou explorado pela União, cujo tráfego e operações portuárias estejam sob a jurisdição de uma Autoridade Portuária.

Operação Portuária - a de movimentação e armazenagem de mercadorias destinadas ou provenientes de transporte aquaviário, realizada no Porto Organizado por operadores portuários.

Operador Portuário - a pessoa jurídica pré-qualificada para a execução de operação portuária na área do Porto Organizado. 
Área do Porto Organizado - a compreendida pelas instalações portuárias, quais sejam, ancoradouros, docas, cais, pontes e píeres de atracação e acostagem, terrenos, armazéns, edificações e vias de circulação interna, bem como pela infraestrutura de proteção e acesso aquaviário ao porto, tais como guias-correntes, quebramares, eclusas, canais, bacias de evolução e áreas de fundeio que devam ser mantidas pela Administração do Porto.

Instalação Portuária de Uso Público Geral - a localizada dentro da área do Porto Organizado, sob a gestão da Administração do Porto, utilizável por todos os operadores portuários.

Instalação Portuária de Uso Público Especial - a localizada dentro da área do Porto Organizado e que, em razão de sua natureza, características, condições ou limitações de tráfego interno, resulte inabilitada para ser usada por mais de um Operador Portuário.

Instalação Portuária de Uso Privativo - explorada por pessoa jurídica de direito público ou privado, dentro ou fora da área do porto, utilizada na movimentação e/ou armazenagem de mercadorias destinadas ou provenientes de transporte aquaviário.

Conselho de Autoridade Portuária - CAP - órgão de deliberação colegiada, de existência obrigatória e funcionamento permanente, com a finalidade de exercer, no que lhe couber, as atribuições fixadas na Lei $n^{\circ} 8.630 / 93$.

Administração do Porto - autoridade portuária responsável pela administração e gestão do Porto Organizado, exercida pela Companhia Docas do Estado de São Paulo - Codesp, nos termos do Decreto no 85.309, de 8-11-80.

Autoridade Marítima - a exercida pelo Ministério da Marinha através da Capitania dos Portos do Estado de São Paulo.

Autoridade Aduaneira - a exercida pelo Ministério da Fazenda através da Inspetoria da Alfândega de Santos.

Assim, as modalidades de exploração dos portos, a partir da Lei de Modernização dos Portos, Lei no 8.630/93, passaram a ser: 1) para uso público, exercida pelas concessionárias; 2) para uso privativo, exclusivo para a 
movimentação de cargas próprias; 3) para uso misto, destinado à movimentação de cargas próprias ou de terceiros, dentro ou fora do porto organizado. A Lei dos Portos determina também que as instalações portuárias de uso privativo, localizadas dentro da área do porto organizado, submetam-se à jurisdição da Autoridade Portuária.

A delimitação da área do porto organizado de Santos é a compreendida, conforme a Portaria-MT no 94, de 15/2/95 (D.O.U. de 17/2/95):

a) pelas instalações portuárias terrestres, existentes na margem direita do estuário formado pelas ilhas de São Vicente e de Santo Amaro, desde a Ponta da Praia até a Alamoa e, na margem esquerda, desde a ilha de Barnabé até a embocadura do rio Santo Amaro, abrangendo todos os cais, docas, pontes, píeres de atracação e de acostagem, armazéns, pátios, edificações em geral, vias internas de circulação rodoviária e ferroviária e, ainda, os terrenos ao longo dessas faixas marginais e em suas adjacências, pertencentes à União, incorporados ou não ao patrimônio do porto de Santos, ou sob sua guarda e responsabilidade, incluindo-se também a Usina Hidrelétrica de Itatinga e a faixa de domínio de suas linhas de transmissão;

b) pela infra-estrutura de proteção e acesso aquaviário, tais como áreas de fundeio, bacias de evolução, canal de acesso até o paralelo 23054'48"S e áreas adjacentes a esse até as margens das instalações terrestres do porto organizado, conforme definido no item "a" anterior, existentes ou que venham a ser construídas e mantidas pela Administração do Porto ou por outro órgão do poder público.

\subsubsection{Evolução da movimentação das cargas do agronegócio no Porto de Santos}

O Porto de Santos movimenta cargas de três tipos: carga geral, granel sólido e granel líquido, caracterizando-se como um porto de múltiplas cargas. Movimentar tipos diferentes de cargas faz com que o porto ganhe vantagens competitivas. Se movimentasse somente um tipo de carga acabaria dependente de 
produtores, usuários ou armadores. Os principais produtos movimentados no porto de Santos são (CODESP, 2011):

- Granel sólido: Tipo de carga mais movimentada no porto. Utiliza-se mão de obra de trabalhadores portuários avulsos. Produtos: açúcar, milho, soja, carvão, enxofre, trigo, sal e polpa cítrica;

- Granel líquido: exige complexidade dos equipamentos e procedimentos. Por este motivo a carga é de responsabilidade dos operadores privados. Produtos: óleo combustível, álcool, óleo diesel, gasolina, GLP, óleo vegetal e suco de laranja;

- Carga geral: apresenta grande crescimento nos últimos anos. Produtos: açúcar, celulose, papel, alumínio cargas especiais, conteinerizadas e veículos.

Nos resultados divulgados no Relatório Anual do Porto de Santos de 2011, o porto encerrou o ano com um movimento recorde de 97,2 milhões de toneladas, superando em 1,2\% os registros de 2010, com 96,1 milhões de toneladas. As importações atingiram 34,3 milhões de toneladas e as exportações totalizaram 62,9 milhões de toneladas (CODESP, 2011).

Considerando a natureza da carga, os sólidos a granel responderam em 2011, pela parcela mais significativa do total, com 45,03 milhões de toneladas movimentadas (46,3\%), seguido da carga geral, 36,04 milhões de toneladas $(37,1 \%)$ e líquidos a granel, 16,09 milhões de toneladas $(16,6 \%)$. Entre as principais cargas, destacaram-se o açúcar (16,93 milhões de toneladas), soja em grãos (9,76 milhões de toneladas), milho (4,56 milhões de toneladas), carvão (3,43 milhões de toneladas) e adubos (3,70 milhões de toneladas) (CODESP, 2011).

De acordo com a CODESP (2011), as exportações e importações através do Porto de Santos somaram US\$ 118,2 bilhões FOB em 2011, 23,3\% acima do apurado em 2010 (US\$ 95,9 bilhões FOB). Outros portos apresentaram os seguintes resultados: Vitória/ES (US\$ 43,2 bilhões); Itaguaí/RJ (US\$ 35,1 bilhões) e Paranaguá/PR (US\$ 32,4 bilhões).

Nas exportações, o principal país de destino das cargas, em toneladas, em 2011 foi a China, responsável por 19,4\% do total exportado pelo porto de Santos (aumento de 23,0\% em 2010), seguido da Holanda (7,1\%), Estados Unidos (5,0\%) Irã $(4,4 \%)$, e Egito e Arábia Saudita (3,2\%). 
Para a China foram exportados desde produtos agrícolas e seus derivados, como soja, açúcar, óleo de soja, algodão, sucos cítricos e milho, até produtos semimanufaturados, algodão, minério de ferro, couros bovinos, matérias vegetais e produtos químicos, entre outros.

As Tabelas 10 e 11 mostram que a soja em grãos chegou a 9.766.826 toneladas, aumento de $16,7 \%$ em relação ao ano passado (8.370.843 toneladas), colocando o produto como o segundo mais movimentado do porto. Com esse resultado, Santos respondeu pela movimentação de $28,7 \%$ da oleaginosa exportada pelo país, seguido por Paranaguá (21,5\%), Rio Grande (17,9\%), São Francisco do Sul $(8,1 \%)$ e São Luís $(7,8 \%)$. O aumento ocorreu, principalmente, devido ao crescimento das exportações para a China, que recebeu cerca de 7,4 milhões de toneladas do produto através do Porto de Santos, $11,5 \%$ acima do total verificado em 2010 (6,7 milhões de toneladas). 
Tabela 10 - Resumo das exportações de cargas no porto de Santos. Comparativo mensal e acumulado (em toneladas).

\begin{tabular}{|c|c|c|c|c|c|c|}
\hline \\
\hline \multirow{2}{*}{ DESCRIÇÃO } & 2010 & 2011 & \multirow{2}{*}{$\begin{array}{l}\text { VAR } \\
\%\end{array}$} & 2010 & 2011 & \multirow{2}{*}{$\begin{array}{l}\text { VAR } \\
\%\end{array}$} \\
\hline & DEZ & EMBRO & & \multicolumn{2}{|c|}{ ATÉ DEZEMBRO } & \\
\hline \multicolumn{7}{|c|}{ EXPORTAÇÃO } \\
\hline $\begin{array}{l}\text { Açúcar } \\
\text { (granel / } \\
\text { sacas) }\end{array}$ & 912.339 & 856.564 & $(6,1)$ & 19.410 .911 & 16.934 .447 & $(12,8)$ \\
\hline -Em sacos & 81.732 & 53.693 & $(34,3)$ & 1.005 .556 & 690.685 & $(31,3)$ \\
\hline $\begin{array}{l}\text {-Em } \\
\text { contêineres }\end{array}$ & 113.350 & 161.271 & 42,3 & 2.248 .787 & 1.913 .913 & $(14,9)$ \\
\hline $\begin{array}{l}\text {-Granel } \\
\text { sólido }\end{array}$ & 717.257 & 641.600 & $(10,5)$ & 16.156 .568 & 14.329.849 & $(11,3)$ \\
\hline Álcool & 119.185 & 74.793 & $(37,2)$ & 1.187 .616 & 1.302 .151 & 9,6 \\
\hline $\begin{array}{l}\text { Café em } \\
\text { grãos }\end{array}$ & 129.819 & 126.907 & $(2,2)$ & 1.193 .359 & 1.388 .042 & 16,3 \\
\hline Carnes & 24.387 & 57.662 & 136,4 & 698.586 & 821.581 & 17,6 \\
\hline $\begin{array}{l}\text { Complexo } \\
\text { soja }\end{array}$ & 131.289 & 853.155 & 549,8 & 10.669 .649 & 12.091 .879 & 13,3 \\
\hline - Em grãos & 20.954 & 636.357 & $2.936,9$ & 8.370 .843 & 9.766 .826 & 16,7 \\
\hline - Peletizada & 110.335 & 216.798 & 96,5 & 2.298.806 & 2.325 .053 & 1,1 \\
\hline Gasolina & 87.666 & 63.917 & $(27,1)$ & 1.412 .395 & 1.070 .557 & $(24,2)$ \\
\hline Milho & 935.950 & 247.358 & $(73,6)$ & 5.558 .000 & 4.569 .508 & $(17,8)$ \\
\hline $\begin{array}{l}\text { - Em } \\
\text { contêineres }\end{array}$ & 2.116 & 3.425 & 61,9 & 26.320 & 26.249 & $(0,3)$ \\
\hline $\begin{array}{l}\text { - Granel } \\
\text { sólido }\end{array}$ & 933.834 & 243.933 & $(73,9)$ & 5.531 .680 & 4.543 .259 & $(17,9)$ \\
\hline $\begin{array}{l}\text { Óleo } \\
\text { combustivel }\end{array}$ & 203.224 & 282.102 & 38,8 & 1.938 .662 & 2.259 .671 & 16,6 \\
\hline $\begin{array}{l}\text { Óleo diesel e } \\
\text { gasóleo }\end{array}$ & 145.270 & 159.982 & 10,1 & 1.286 .348 & 1.649 .974 & 28,3 \\
\hline Carnes & 24.387 & 57.662 & 136,4 & 698.586 & 821.581 & 17,6 \\
\hline $\begin{array}{l}\text { Sucos } \\
\text { cítricos }\end{array}$ & 121.144 & 172.268 & 42,2 & 1.941 .848 & 2.011 .784 & 3,6 \\
\hline $\begin{array}{l}\text { - Em } \\
\text { contêineres }\end{array}$ & 17.198 & 17.605 & 2,4 & 158.818 & 179.236 & 12,9 \\
\hline $\begin{array}{l}\text { - Granel } \\
\text { líquido }\end{array}$ & 103.946 & 154.66 & 48,8 & 1.783 .030 & 1.832 .548 & 2,8 \\
\hline $\begin{array}{r}\text { Sub-Total } \\
\text { Exportação }\end{array}$ & 2.810 .273 & 2.894 .708 & 3,0 & 45.297 .374 & 44.099 .594 & $(2,6)$ \\
\hline Outros & 1.651 .733 & 1.854 .789 & 12,3 & 18.869 .181 & 18.777 .383 & $(0,5)$ \\
\hline $\begin{array}{l}\text { Total } \\
\text { Exportação }\end{array}$ & 4.462 .006 & 4.749 .497 & 6,4 & 64.166 .555 & 62.876 .977 & $(2,0)$ \\
\hline
\end{tabular}

Fonte: CODESP (2011). 
Tabela 11 - Resumo das importações e movimentações de contêineres no porto de Santos. Comparativo mensal e acumulado (em toneladas).

\begin{tabular}{|c|c|c|c|c|c|c|}
\hline \multirow{2}{*}{ DESCRIÇÃO } & & & \multirow{2}{*}{$\begin{array}{c}\text { VAR } \\
\%\end{array}$} & & & \multirow{2}{*}{$\begin{array}{l}\text { VAR } \\
\%\end{array}$} \\
\hline & \multicolumn{2}{|c|}{ DEZEMBRO } & & \multicolumn{2}{|c|}{$\begin{array}{l}2010 \quad 2011 \\
\text { ATÉ DEZEMBRO }\end{array}$} & \\
\hline \multicolumn{7}{|c|}{ IMPORTAÇÃO } \\
\hline Adubo & 262.388 & 310.226 & 2,1 & 2.261 .036 & 3.704 .195 & 63,8 \\
\hline Amonia & 17.000 & 49.824 & 193,1 & 318.999 & 313.337 & $(1,8)$ \\
\hline Carvão* & 348.168 & 175.653 & $(49,5)$ & 3.675 .736 & 3.429 .622 & $(6,7)$ \\
\hline Enxofre & 116.133 & 213.620 & 83,9 & 1.852 .274 & 2.016 .968 & 8,9 \\
\hline GLP & 84.725 & 61.538 & $(27,4)$ & 969.120 & 857.059 & $(11,6)$ \\
\hline $\begin{array}{l}\text { Minério de } \\
\text { Ferro }\end{array}$ & 42.794 & 19.746 & $(53,9)$ & 779.462 & 860.973 & 10,5 \\
\hline $\begin{array}{l}\text { - Em } \\
\text { contêineres }\end{array}$ & - & 17 & - & 1.194 & 1.788 & 49,7 \\
\hline $\begin{array}{l}\text { - Granel } \\
\text { sólido }\end{array}$ & 42.794 & 19.729 & $(53,9)$ & 778.268 & 859.185 & 10,4 \\
\hline Nafta & 91.348 & 2.915 & $(96,8)$ & 921.062 & 356.746 & $(61,3)$ \\
\hline Sal & 96.152 & 118.795 & 23,5 & 981.209 & 1.102 .669 & 12,4 \\
\hline $\begin{array}{l}\text { Soda } \\
\text { Caustica }\end{array}$ & 70.806 & 80.264 & 13,4 & 823.800 & 886.545 & 7,6 \\
\hline $\begin{array}{l}\text { Trigo (grãos } \\
\text { e farelo)* }\end{array}$ & 106.627 & 121.554 & 14,0 & 1.527 .150 & 1.288 .892 & $(15,6)$ \\
\hline $\begin{array}{r}\text { Sub-Total } \\
\text { Importação }\end{array}$ & 1.268 .886 & 1.145 .135 & $(9,8)$ & 14.109 .848 & 14.817 .006 & 5,0 \\
\hline Outros & 170.444 & 1.748 .779 & 18,9 & 17.748 .855 & 19.476 .325 & 9,7 \\
\hline $\begin{array}{l}\text { Total } \\
\text { Importação }\end{array}$ & 2.739.330 & 2.893.914 & 5,6 & 31.858.703 & 34.293.331 & 7,6 \\
\hline Total Geral & 7.201 .336 & 7.643.411 & 6,1 & 96.025 .258 & 97.170 .308 & 1,2 \\
\hline \multicolumn{7}{|c|}{ CONTEINERES - IMPORTAÇÃO E EXPORTAÇÃO } \\
\hline Unidades & 150.992 & 169.991 & 12,6 & 1.762 .205 & 1.915 .292 & 8,7 \\
\hline TEU & 234.638 & 265.628 & 13,2 & 2.722 .225 & 2.985 .922 & 9,7 \\
\hline Tonelagem & 2.456 .978 & 2.846 .592 & 15,9 & 29.922 .511 & 31.605 .104 & 5,6 \\
\hline
\end{tabular}

Fonte: CODESP (2011).

A Tabela 12 mostra as movimentações de contêineres no Porto de Santos no período de 2007 a 2011. No ano de 2010 houve uma recuperação em relação à crise de 2009, sendo que em 2011 apresentou recorde no número total de contêineres para exportação. Em 2011, a movimentação de contêineres atingiu 2.985 milhões de TEU (unidade relativa a um contêiner de 20 pés), apresentando crescimento em relação a 2010. 
Tabela 12 - Movimentação de contêineres. 2007 - 2011.

\begin{tabular}{|c|c|c|c|c|c|c|c|c|c|}
\hline & \multicolumn{3}{|c|}{ IMP + EXP (EM UNIDADES) } & \multicolumn{3}{|c|}{ IMP + EXP (EM TEUS) } & \multicolumn{3}{|c|}{ IMP + EXP (EM TONELAGEM) } \\
\hline Período & LONGO CURSO & CABOTAGEM & TOTAL & LONGO CURSO & CABOTAGEM & TOTAL & LONGO CURSO & CABOTAGEM & TOTAL \\
\hline 2007 & 1.489 .503 & 165.210 & 1.654 .713 & 2.265 .616 & 267.284 & 2.532 .900 & 24.713 .835 & 2.672 .839 & 27.386 .674 \\
\hline 2008 & 1.580 .113 & 163.299 & 1.743 .412 & 2.406 .529 & 268.446 & 2.674 .975 & 26.947 .238 & 2.474 .617 & 29.421 .855 \\
\hline 2009 & 1.328 .720 & 142.647 & 1.471 .367 & 2.013 .437 & 238.751 & 2.252 .188 & 22.806 .662 & 2.199 .154 & 25.005 .816 \\
\hline 2010 & 1.612 .876 & 149.329 & 1.762 .205 & 2.474 .105 & 248.120 & 2.722 .225 & 27.538 .666 & 2.383 .845 & 29.922 .511 \\
\hline 2011 & 1.736 .889 & 178.403 & 1.915 .292 & 2.691 .144 & 294.778 & 2.985 .922 & 28.858 .102 & 2.747 .002 & 31.605 .104 \\
\hline
\end{tabular}

Fonte: Adaptado de CODESP (2011).

Em 2011, atracaram no Porto de Santos 5.526 navios, valor pouco acima que em 2010 com 5.425 navios. Em 2011 foram 515 atracações de navios de cabotagem e 5.011 de longo curso, conforme Tabela 13.

Tabela 13 - Toneladas médias movimentadas por navio e navegação.

\begin{tabular}{|r|c|r|r|r|r|r|r|r|r|}
\hline & \multicolumn{3}{|c|}{ LONGO CURSO } & \multicolumn{3}{c|}{ CABOTAGEM } & \multicolumn{3}{c|}{ TOTAL } \\
\hline Período & \multicolumn{1}{c|}{$\mathrm{t}$} & QTD. NAVIOS & $\mathrm{t} /$ Navio & \multicolumn{1}{c|}{$\mathrm{t}$} & QTD. NAVIOS & $\mathrm{t} /$ Navio & $\mathrm{t}$ & QTD. NAVIOS & $\mathrm{t} /$ Navio \\
\hline 2007 & 70.111 .629 & 4.874 & 14.385 & 10.664 .238 & 609 & 17.511 & 80.775 .867 & 5.483 & 14.732 \\
\hline 2008 & 72.219 .503 & 4.915 & 14.694 & 8.838 .989 & 599 & 14.756 & 81.058 .492 & 5.514 & 14.700 \\
\hline 2009 & 73.083 .625 & 4.775 & 15.305 & 10.110 .504 & 638 & 15.847 & 83.194 .129 & 5.413 & 15.369 \\
\hline 2010 & 85.636 .826 & 4.896 & 17.491 & 10.388 .432 & 529 & 19.638 & 96.025 .258 & 5.425 & 17.701 \\
\hline 2011 & 86.582 .058 & 5.011 & 17.278 & 10.588 .250 & 515 & 20.560 & 97.170 .308 & 5.526 & 17.584 \\
\hline
\end{tabular}

Fonte: Adaptado de CODESP (2011).

O porto de Santos possui participação significativa na balança comercial brasileira. Na Tabela 14, verifica-se a representatividade das exportações e importações via Porto de Santos. O valor total da balança comercial brasileira em 2011 foi de US\$ 482,3 bilhões. Segundo dados da SECEX/DEPLA/MDIC, a participação do Porto de Santos na balança comercial brasileira nas exportações, em 2011 foi de 24,5\%, enquanto em 2010 foi de 24,8\%. No Gráfico 2 são apresentadas as principais participações dos portos brasileiros na balança comercial em 2011.

Tabela 14 - Evolução do Comércio Exterior Brasileiro - 2002 a 2011.

\begin{tabular}{|r|r|r|r|r|r|r|r||r|r|r|}
\hline & \multicolumn{3}{|c|}{ PIB } & \multicolumn{2}{|c|}{ EXP (FOB) BRASIL } & \multicolumn{2}{|c|}{ EXP (FOB) SANTOS } & \multicolumn{2}{c|}{ IMP (FOB) BRASIL } & \multicolumn{3}{c|}{ IMP (FOB) SANTOS } & \multicolumn{2}{c|}{ SALDO } \\
COMERCIAL
\end{tabular}

Fonte: Adaptado de CODESP (2011). 


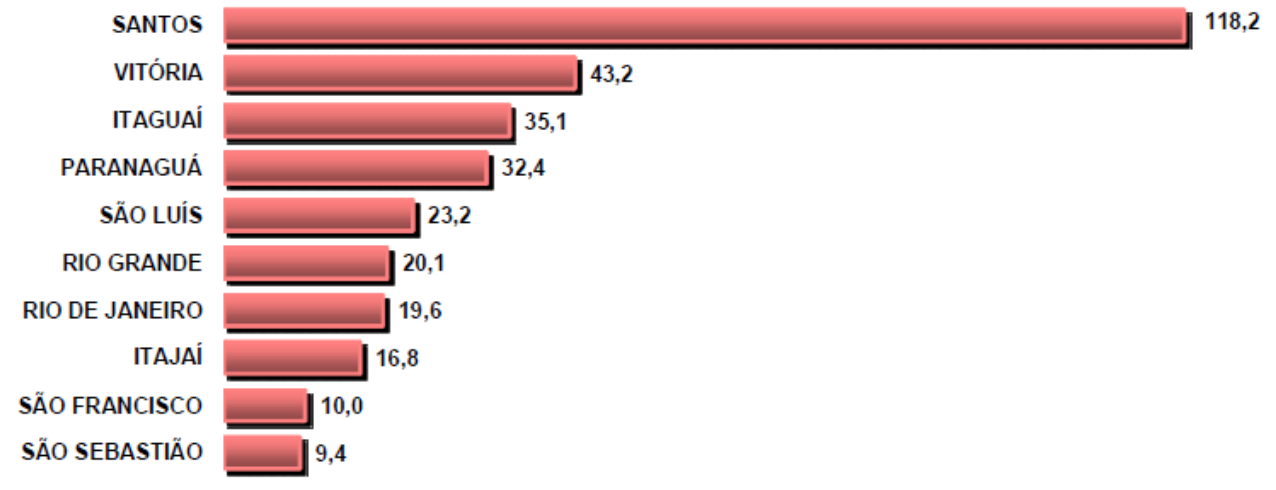

Gráfico 2 - Principais participações dos portos - 2011. Balança comercial (US\$ bi). Fonte: CODESP (2011).

Os dados obtidos pela CODESP (2011) são do Sistema Alice, extraídos do site do Ministério de Desenvolvimento Indústria e Comércio (MDIC). Esse sistema computa as informações do comércio exterior, por isso não considera a carga movimentada por cabotagem e nem a tara dos contêineres. O período de apuração é o do registro no SISCOMEX. Por essas razões, o peso da carga obtida no MDIC é inferior ao apurado pela CODESP, que considera a carga por cabotagem, a tara dos contêineres e as cargas de reembarque são registradas duas vezes, uma na descarga e outra no reembarque.

\subsubsection{Acessos Ferroviários ao Porto de Santos}

O acesso do interior do estado de São Paulo ao porto de Santos pelas ferrovias, observado na Figura 13, pode ser realizado através de três companhias ferroviárias: ALL (América Latina Logística), FCA (Ferrovia Centro Atlântica), e MRS. A ALL comprou as ferrovias Ferroban, Ferronorte e Novoeste, no ano de 2006. Com isso, a ALL passa a ser a principal concessionária ferroviária com acesso a Santos.

A ALL é a ferrovia com maior acesso ao interior do estado de São Paulo. Possui extensões com bitola estreita $(2.422 \mathrm{~km})$, larga $(1.513 \mathrm{~km})$ e mista $(301$ km). A Ferrovia Centro Atlântica, FCA, pertencente a VALE, é a maior ferrovia brasileira em extensão, com mais de $8.000 \mathrm{~km}$ de extensão. Já a MRS possui acesso direto a terminais portuários em Santos: Libra T37, Santos Brasil, Tecondi, União Terminais. 


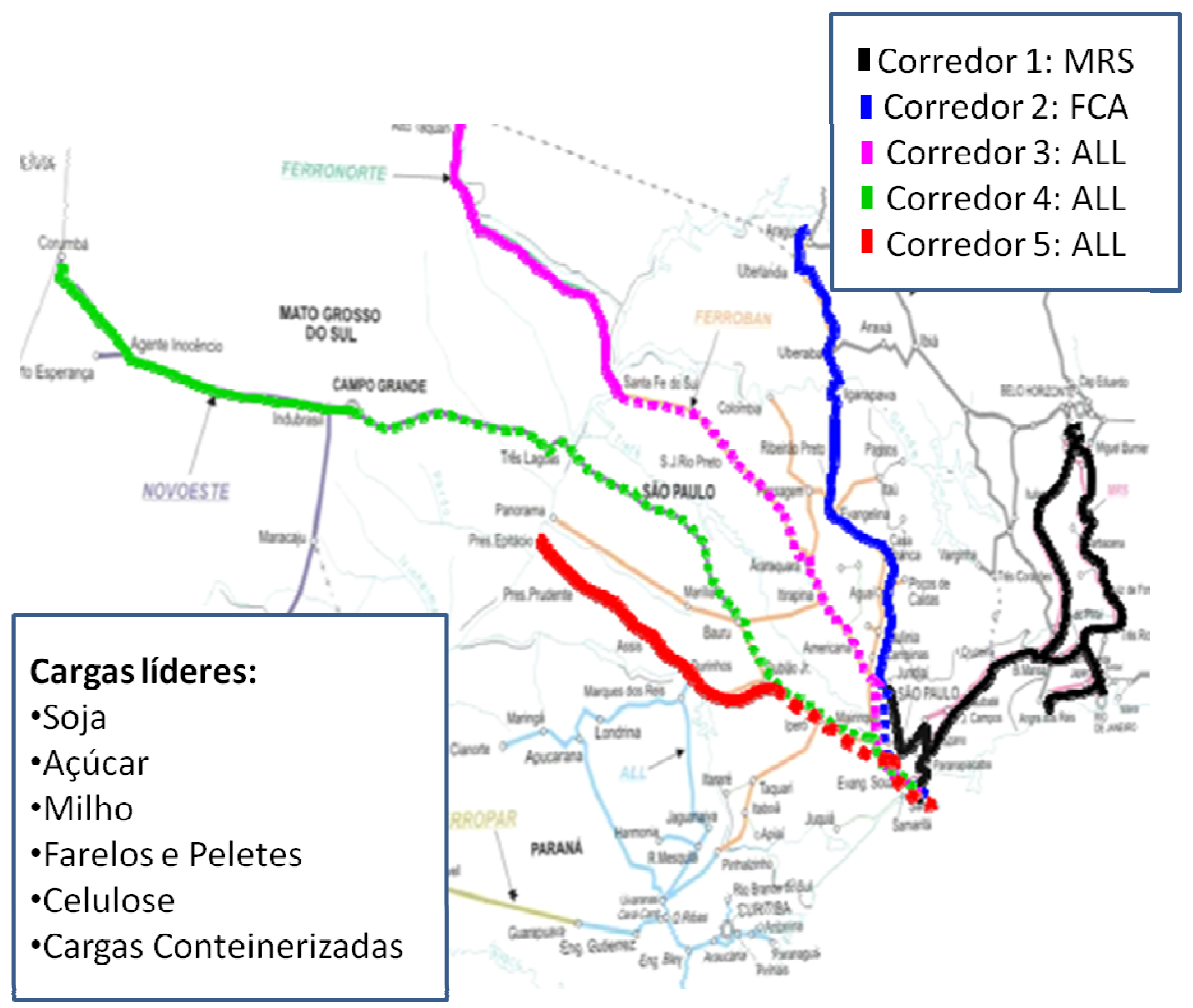

Figura 13 - Malha Ferroviária do Porto de Santos. Fonte: CODESP (2010).

É importante destacar os pontos críticos de acesso a Santos no que tange os seus problemas logísticos. O "Estudo de Acessibilidade ao Porto de Santos", recentemente produzido pela Universidade de São Paulo (USP), e divulgado pela CODESP e Secretaria Especial de Portos (SEP), em 2010, destaca algumas soluções encontradas para o problema logístico no acesso ferroviário ao porto.

No setor ferroviário, as soluções encontradas seriam: abertura de um pátio entre a Rodovia Cônego Domênico Rangoni, antiga Piaçaguara-Guarujá, e a Ilha Barnabé; a duplicação do acesso a terminais da margem direita; a separação das linhas de acesso ao Corredor de Exportação, na Ponta da Praia; um novo pátio na região de Outeirinhos; e a melhoria da segurança e da velocidade das composições.

Um grande problema apontado pelo estudo é o gargalo existente no trecho da Cremalheira, ou seja, na descida da Serra do Mar, que prejudica o transporte de minério para o Porto. Por isso, a carga chega a ser transportada por caminhões, sobrecarregando os acessos rodoviários. Assim, é importante que as 
concessionárias ALL e MRS, ampliem suas capacidades de acesso ao cais devido o aumento da demanda.

\subsubsection{Acessos Rodoviários ao Porto de Santos}

Os acessos rodoviários ao Porto de Santos são feitos pela rodovia Anchieta - Imigrantes (SP-150 e SP-160), Cônego Domênico Rangoni, Rio Santos (BR101) e Padre Manoel da Nóbrega (SP-55). A partir de São Paulo o trajeto é feito pelo Sistema Anchieta (SP-150) e Imigrantes (SP-160). A partir do Litoral Sul, pela Rodovia Padre Manoel da Nóbrega (SP-055), e em seguida, o acesso 291 até a entrada da Rodovia dos Imigrantes ou até a Ponte Pênsil de São Vicente. A partir do Litoral Norte, da rodovia Rio-Santos (BR-101), chega-se ao Guarujá. Na Figura 14, o mapa com as rodovias que dão acesso a Santos.

São Paulo

$\bullet$

$\mathrm{SP}$

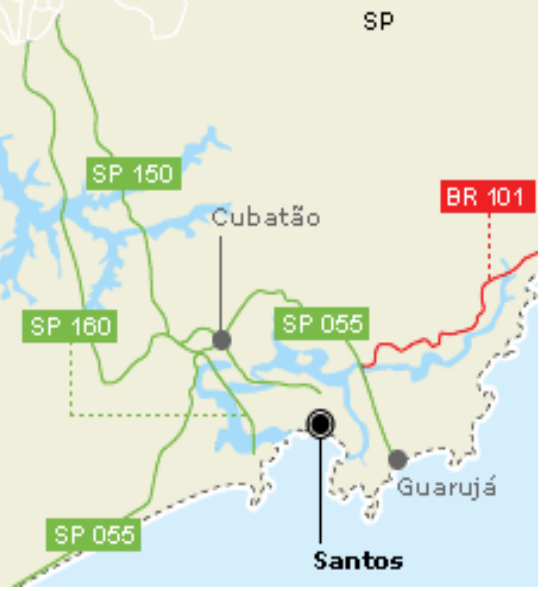

Figura 14 - Principais Rodovias no Estado de São Paulo.

No modal rodoviário, Sistema Anchieta - Imigrantes possui movimentação de 33 milhões de veículos ao ano. O Estudo de Acessibilidade ao Porto de Santos (2010) destaca que este sistema, nos próximos quatro anos, ficará saturado, chegando a mais de $85 \%$ de sua capacidade preenchida. Além disso, com a abertura do Trecho Sul do Rodoanel, o Viaduto 31 de Março, no bairro do Jardim Casqueiro, em Cubatão, nas imediações da Usiminas, passou a receber maior trânsito de caminhões e carretas, o que significa que essa obra precisa passar por duplicação, além do gargalo no entroncamento da Via Anchieta com a Rodovia Cônego Domênico Rangoni. 
O estudo recomenda ainda que estas atuações sejam feitas em conjunto com os terminais portuários para que haja melhor dimensionamento e planejamento da oferta, além de controlar melhor o acesso de veículos e atuar na melhoria das vias, com sinalização e pavimentação adequadas.

Apesar de existirem falhas e muitas oportunidades de melhorias, o porto de Santos continuará movimentando e atraindo cargas de todo o país. Assim sendo, é tão importante que terminais marítimos sejam construídos, ampliados e modernizados o quanto antes.

\subsubsection{Problemas no Porto de Santos}

O Porto de Santos sempre enfrentou muitos problemas em sua infraestrutura. Apesar disso, a cada ano, são crescentes as movimentações no porto e é a principal via de entrada e saída de mercadorias do país. Os problemas logísticos se mostram cada vez mais urgentes. Os principais podem ser citados a seguir (CODESP, 2011):

- Falta de infraestrutura adequada: falta de sinalização, fiscalização e segurança;

- Grandes congestionamentos no acesso terrestre (rodoviário e ferroviário) ao porto durante o escoamento de soja. As filas de caminhões que se formam nos portos para descarregamento são intermináveis, com quilômetros de extensão, acarretando atrasos nos embarques e prejuízos. Por vezes, caminhões bloqueiam a ferrovia e impedem a passagem de trem, gerando atrasos. Outro agravante é a superlotação dos pátios e falta de estacionamentos para caminhões.

- Falta de equipamentos (carregadores de navio e esteiras) modernos para o carregamento e descarregamento dos navios. Além disso, as chuvas são determinantes no embarque dos navios, já que a maioria dos granéis, como açúcar e soja, solto ou em saco, não podem se molhar. Assim, com a ocorrência de chuvas, os porões dos navios devem ser fechados e o embarque é interrompido.

- Grandes congestionamentos no acesso marítimo (navios) para atracação nos portos, sendo o tempo de espera de navios muito grandes, ficando dias em alto-mar esperando autorização para atracar. Além da baixa quantidade de píeres, e a falta de coordenação entre o que é enviado e o que pode ser recebido pelo porto são outros problemas durante o escoamento da soja em grão para 
exportação. O congestionamento não é somente em terra, sendo também no mar. O recorde da fila, registrado em 2010, foi de 160 navios esperando para atracar.

- Pouca disponibilidade de armazenagem. A superlotação dos terminais no porto faz com que contêineres fiquem parados esperando por muito tempo. Com isso, os atrasos são frequentes.

As dificuldades fizeram os custos de movimentação portuária aumentar. A dragagem para aprofundar o canal de acesso ao porto, passando para 15 metros de profundidade e o alargamento do canal de navegação, de 150 para 220 metros, estão em andamento, o que deve melhorar o fluxo de navios e aumentar $30 \%$ da capacidade operacional do porto. Em longo prazo, a infraestrutura precisa melhorar diante do crescimento de mercados como a soja.

\subsubsection{Investimentos}

O porto de Santos ganhou novas projeções para movimentação de carga de importações e exportações. A nova previsão é de 230 milhões de toneladas movimentadas por ano em 2025. Em 2011, o movimento de cargas ultrapassou 97 milhões de toneladas. Para isto, estão sendo realizadas algumas melhorias no porto com um plano de investimentos, ultrapassando US\$ 6,0 bilhões até 2025.

O novo plano de crescimento do cais santista, apresentado pela CODESP no Plano de Expansão do Porto (2010), é a base para a elaboração do novo plano diretor. O projeto foi financiado pelo BID e prevê o aproveitamento de áreas dentro e fora dos limites do porto organizado. Mas para isto, a capacidade dos atuais acessos ao porto deve suportar um volume de cargas tão superior aos níveis atuais. Os volumes projetados de 230 milhões de toneladas em 2025 somente serão alcançados com investimentos em infraestrutura de acesso. Os investimentos no curto prazo no porto e seus respectivos valores anunciado pela CODESP em 2010 são:

- Dragagem e serviços de engenharia civil: US\$ 438 milhões

-Dragagem do Canal aprofundando até $15 \mathrm{~m}$, Investimento:

US\$ 112 milhões - PAC1

-Remoção de Destroços (Ais Giorgios - embarcação que naufragou no estuário do Porto de Santos na década de 1970), Investimento: US\$10 milhões - PAC 
-Derrocagem de Pedras (Teffé / Itapema), Investimento: US\$ 17 milhões - PAC1

-Reforço do Pier (berços da Alamoa e Ilha de Barnabé, reforço do cais para aprofundamento dos berços entre os armazéns 12 e 23), Investimento: US\$ 170 milhões - PAC2

-Dragagem do Canal aprofundando até $17 \mathrm{~m}$, Investimento: US\$ 107 milhões - PAC2

-Monitoramento ambiental da dragagem e da derrocagem de pedras, Investimento: US\$ 22 milhões - PAC2

A manutenção da dragagem é estimada em US\$ 40 milhões pelos próximos dois anos (3,8 milhões de $\mathrm{m}^{3}$ por ano).

- Acesso rodoviário: US\$ 487 milhões

$$
\begin{aligned}
& \text {-Avenida Perimetral Margem Direita - Primeira Fase, } \\
& \text { Investimento: US\$ } 75 \text { milhões - PAC1 } \\
& \text {-Avenida Perimetral Margem Direita - Segunda Fase, } \\
& \text { Alamoa - Saboó, Investimento: US\$ } 35 \text { milhões - PAC2 } \\
& \text {-Avenida Perimetral Margem Esquerda - Primeira Fase, } \\
& \text { Investimento: US\$ } 40 \text { milhões - PAC1 } \\
& \text {-Avenida Perimetral Margem Esquerda - Segunda Fase, } \\
& \text { Investimento: US\$ } 170 \text { milhões - PAC2 } \\
& \text {-Passagem Inferior (Valongo), Investimento: US\$ } 167 \\
& \text { milhões - Tesouro Nacional }
\end{aligned}
$$

- Aumento de capacidade dos berços: US $\$ 1,89$ bilhão

-Investimentos privados em andamento:

-Itamaraty - Granéis sólidos de origem vegetal,

Investimento: US\$ 62 milhões - Concessão

-NST - Terminal de Suco de Laranja, Investimento:

US\$ 41 milhões - Concessão

-Expansão do TECONDI (Terminal de Containers),

Investimento: US\$ 103 milhões - Concessão

-Brasil Terminal Portuário - BTP (Terminal

Multimodal), Investimento : US\$ 890 milhões - Concessão 
-Embraport - Terminal Multimodal, Investimento : US\$ 670 milhões - Grupo Coimex

-Investimentos no Porto de Santos:

-Construção de 2 píeres de atracação e ponte de acesso, no Terminal da Alamoa, Investimento: US\$ 40 milhões PAC 2

-Construção de 3 píeres de atracação e pontes de acesso na Ilha de Barnabé, Investimento: US\$ 85 milhões - PAC 2 


\section{Modelagem e simulação de sistemas}

Simulação é o processo de elaborar modelos de um sistema real e de conduzir experimentos, com a finalidade de compreender o comportamento do sistema ou de avaliar as possíveis estratégias para operação do sistema (Saliby et al., 1998). Simulação de sistemas é uma técnica tradicional da pesquisa operacional. É uma das ferramentas mais importantes e úteis para analisar o projeto e a operação de sistemas complexos. Quando certos estudos de planejamento são executados e a solução aparentemente é complexa, muitas vezes se faz uso da simulação, para observar se o sistema tem um funcionamento eficiente ou pode ser otimizado. Existem diversas definições para simulação. Para Gordon (1978), apud Bueno da Costa (2002), é definido como:

"Simulação de sistemas é a técnica de solucionar problemas observando o desempenho no tempo de um modelo dinâmico do sistema".

Para Bueno da Costa (2002), simulação pode ser definida como:

"Simulação de sistemas é o processo de construção de um modelo representativo de um sistema real, e a experimentação no mesmo. Os resultados das experimentações, após análises, apresentam uma visão futura do sistema. As informações geradas auxiliam nas tomadas de decisão, necessárias no momento presente, e contribuem para uma melhor compreensão do sistema estudado".

A grande vantagem da simulação reside no fato de permitir a análise de diversas alterações no cenário virtual, sem o custo e o risco de atuar no cenário real. Assim, o estudo de modelagem de sistemas envolve modificações de equipamentos, de lay-out, reengenharia, dimensionamento, entre outros. Para isto, é preciso atentar para os gargalos do sistema, ou seja, onde podem ocorrer filas.

As técnicas disponíveis para a modelagem de sistemas são a Teoria das Filas e a Simulação. Atualmente, a simulação é a mais usada já que a teoria das filas aborda a modelagem por meio de fórmulas matemáticas, sendo que a quantidade de problemas que podem ser resolvidos matematicamente é limitada. Já a simulação não utiliza fórmulas matemáticas para representar cada componente do sistema e permite representar o funcionamento do sistema real, antes de efetuar alterações no sistema real. Com a simulação visual, tal técnica teve ótima aceitação, por ter menor nível de complexidade e ser mais fácil de visualizar o sistema como um todo. 
As principais vantagens da simulação, segundo Rubinstein e Melamed (1998) apud Maligo (2005) são:

- O sistema pode ser tão complexo que se for usada formulação em termos de simples equações matemáticas pode ser muito difícil o cálculo dos estados dos seus componentes. A maioria dos sistemas econômicos cai nesta categoria.

- Permite estudos de sistemas reais sem modificá-los, com velocidade e baixo custo.

- Simulação tem sido uma ferramenta extremamente efetiva para tratar problemas como operações em empresas e indústrias.

- Pode ser usada para experimentar com novos cenários, de forma a prever o comportamento do sistema sob novas circunstâncias.

- A simulação fornece um laboratório experimental, permitindo ao usuário descobrir melhores controles para o sistema em estudo.

- Simulação torna possível estudar sistemas dinâmicos em horizontes de tempo real, comprimido ou expandido.

Assim, a simulação encontra um vasto campo de aplicação. Segundo Prado (2010), suas principais aplicações são:

- Linhas de Produção: Vários cenários podem ser aplicados à modelagem, desde empresas de manufatura até as de mineração. Casos como modificação em sistemas já existentes, com aumento da atual produção, por troca de equipamentos ou adição de novos produtos e com a previsão de possíveis gargalos, são possíveis de serem modelados. Outros exemplos, como políticas de estoques dentro de uma empresa e planejamento de um setor de produção com objetivo de obter melhor fluxo, podem ser feitos através de simulação.

- Logística: esta área tem apresentado crescente uso de simulação. Desde fábricas até meios de transportes podem ser usados na simulação. Por exemplo, o transporte ferroviário pode ser analisado com o objetivo de minimizar a movimentação de vagões vazios, ou até mesmo representando problemas envolvendo o pátio e máquinas de serviços. No transporte rodoviário, é aplicado para se estabelecer melhores fluxos de veículos, ou dimensionar um pedágio. No transporte marítimo e aéreo pode ser aplicada a simulação de forma a diminuir filas em pátios dos portos e dimensionar portos ou aeroportos. 
- Comunicações: pela modelagem de filas, uma rede de comunicações pode ser simulada. Empresas de call center podem ser dimensionadas com o correto número de atendentes, para se obter o nível de serviço adequado ao cliente.

Atualmente, o uso largamente difundido dos microcomputadores, com sua grande capacidade de processamento, facilitam a utilização dos softwares de simulação. Alguns destes softwares são dotados de interfaces amigáveis que permitem a sua utilização sem que o usuário precise se ocupar com a formulação teórica associada ao problema. As linguagens mais conhecidas são: GPSS, GASP, SIMAN, ARENA, PROMODEL, AUTOMOD, TAYLOR, entre outros.

A metodologia para desenvolver modelos de simulação é análoga à metodologia apresentada pela pesquisa operacional. Na Figura 15 é possível visualizar as etapas de um processo de simulação e suas interações.

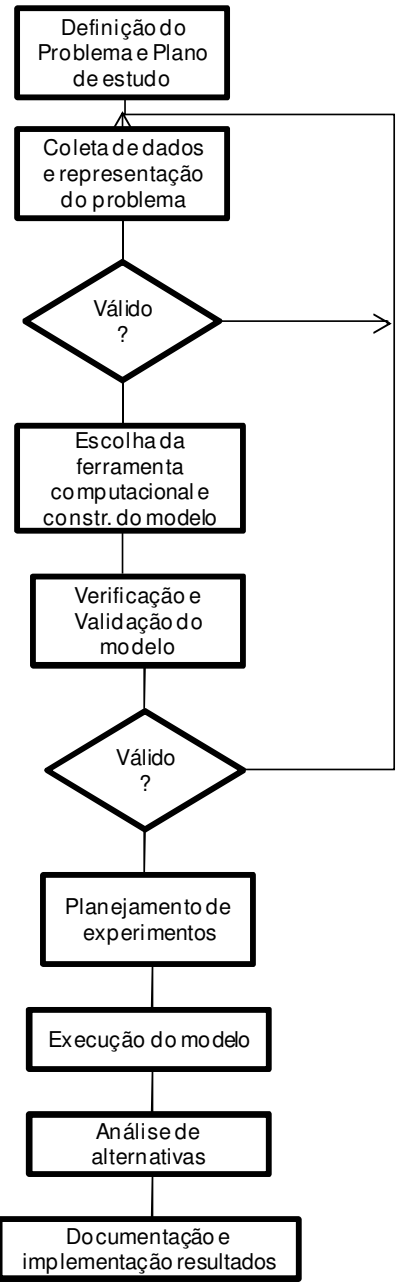

Figura 15 - Etapas do Processo de Simulação.

Fonte: Bueno da Costa (2002). 
A definição do problema é uma etapa de extrema importância para todo o processo de simulação. Nesta fase deve ser absorvido o maior número de informações que devem ser analisadas a fim de definir o problema no nível de objetivos, restrições e complexidade. Conforme a simulação avança, novos problemas são identificados e revisões devem ser feitas no modelo para obter melhores soluções.

Depois de estabelecer a situação a ser tratada, deve-se passar para a fase de representação. No caso da simulação, é o fato de traduzir o sistema real para um diagrama de fluxo lógico. O diagrama representará o problema através de associações feitas entre as entidades e as atividades, ou seja, é criado um modelo representativo de um sistema real.

Após a escolha da ferramenta computacional, o desenvolvimento do modelo vai depender da ferramenta computacional escolhida. O resultado poderá ser um simulador tradicional ou um complexo sistema de simulação. $\mathrm{Na}$ fase de verificação, o modelo desenvolvido deve corresponder ao idealizado, através de testes exaustivos no simulador. Já na etapa da validação, o modelo desenvolvido deve representar bem o sistema real.

No planejamento dos experimentos, é executado o modelo computacional sob os diversos cenários de simulação estabelecidos. Os cenários são tratados individualmente, com a preocupação de se estabelecer exatamente os pontos de início e fim da simulação, para efeito de análises estatísticas. A execução do modelo é a fase tática do planejamento de experimentos e, como resultado desta fase, é o estabelecimento de diversos cenários que serão rodados. A análise das alternativas de ação consiste em fazer inferências a partir dos dados gerados na execução do modelo, sendo que estes dados de saída precisam ser tratados e analisados (Bueno da Costa, 2002).

Assim, foi escolhido para utilização o software de simulação ARENA, versão 12.0, desenvolvido pela Systems Modelling Corporation e distribuído no Brasil pela Paragon, que possui a linguagem SIMAN. Segundo a Paragon, o ARENA possui as seguintes características:

- ambiente gráfico integrado de simulação, que contém todos os recursos para modelagem de processos, desenho e animação, análise estatística e análise de resultados; 
- conecta os recursos de uma linguagem de simulação à facilidade de uso de um simulador, em um ambiente gráfico integrado;

- todo o processo de criação do modelo de simulação é por fluxogramas, não sendo necessário escrever códigos no ARENA;

- a tecnologia diferencial do ARENA é a criação templates, ou seja, uma coleção de objetos e ferramentas de modelagem, que permitem ao usuário descrever o comportamento do processo em análise, através de respostas às perguntas pré-elaboradas, sem programação, de maneira visual e interativa;

- funcionalidades: MS Office, Visual Basic e C++ compatíveis; inclui VBA (permite ao programador desenvolver rotinas em VB); possui assistente para criação de modelos; input e output analyzer para tratamento de dados e análise de resultados; manuais on-line; entre outros.

\subsection{Mapeamento do processo}

O modelo de simulação desenvolvido é baseado na operação do Porto de Santos, desde a chegada dos navios na área externa disponível para fundeio, passando pelo embarque da carga nos navios e a saída dos navios. A carga a ser considerada no modelo é a soja que será utilizada para embarque nos navios destinados à exportação. Desta forma, será possível mensurar o tempo gasto na operação de embarque, o número de navios atendidos e o tempo médio de navios na fila do canal de acesso do Porto. Por fim, serão analisadas alternativas, com o objetivo de gerar melhoria na operação do porto a fim de torná-lo mais eficiente.

A soja é escoada pelo Porto de Santos, através do Corredor de Exportação que possui três berços de atracação no Cais Público, com 608 metros de extensão e 13 metros de profundidade. A administração do Porto determina que qualquer navio que chegar à barra do porto de Santos, ou ao se movimentar por quaisquer motivos, deverá contatar o Centro de Controle do Serviço de Praticagem, via VHF, informando a posição e hora de fundeio.

Para o melhor entendimento do modelo, é importante detalhar os elementos do processo que o compõem. É apresentado o fluxograma que permite mapear os eventos do processo de embarque da soja nos navios que chegam ao Porto de Santos destinados à exportação. As atividades necessárias para o embarque da soja estão descritas na Figura 16. 
A abordagem para a modelagem inicia-se com a representação da chegada dos navios que estão em áreas de fundeio externas, com programação de atracação definida para as próximas 24 horas. Assim, para todo o navio que entrar no modelo, é considerado que o mesmo já possui autorização para atracar e somente está aguardando a sua liberação. Enquanto aguarda, ocupa a área de fundeio destinada para isto. O modelo trabalha com o sistema FIFO (First in First Out). Em paralelo, é informado o tipo de carga que o navio está contratado para embarcar.

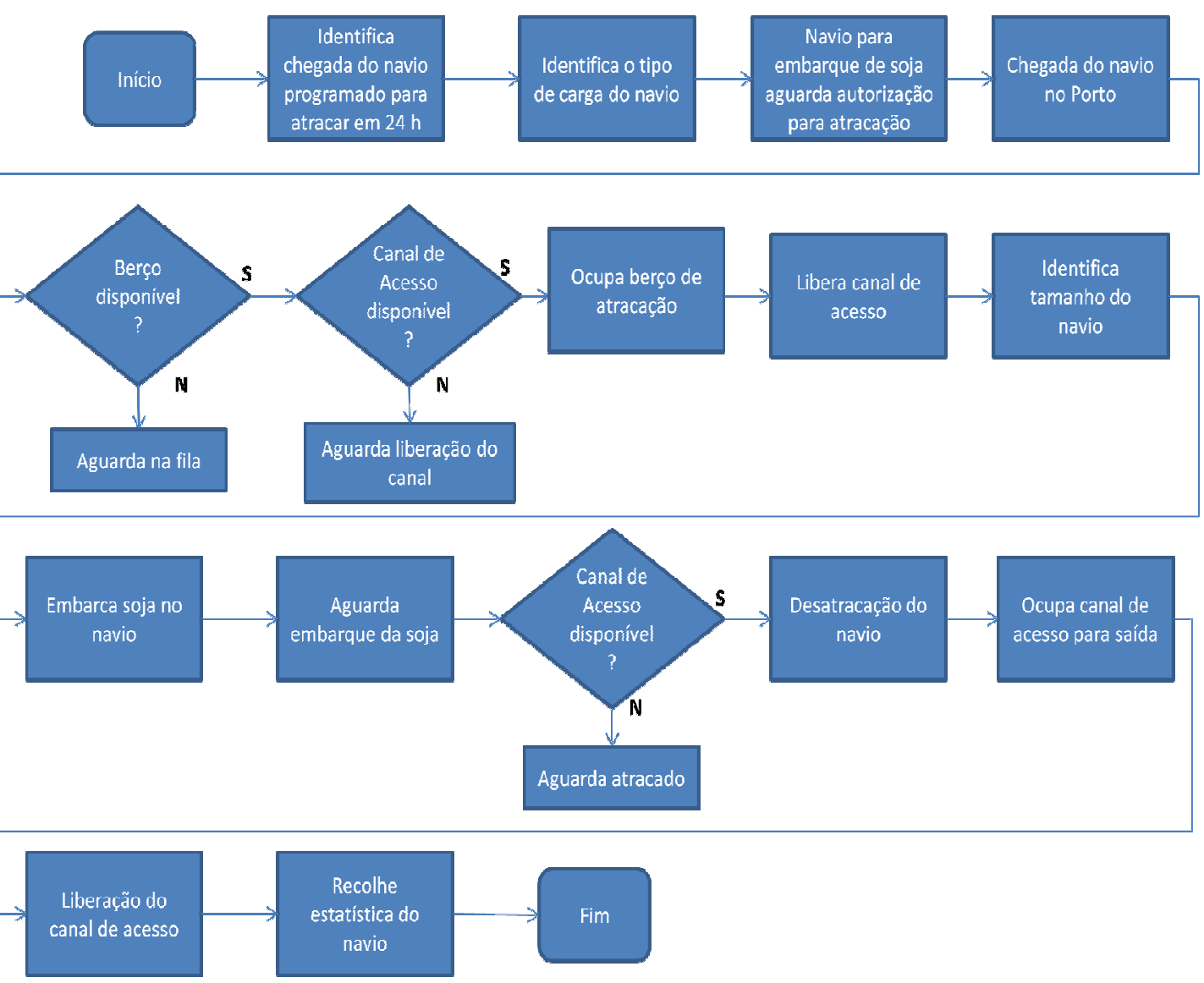

Figura 16 - Fluxograma do processo de embarque de soja no Porto de Santos.

Para o navio receber a autorização de atracação, deve existir algum berço desocupado e, além disto, o canal de acesso do porto deve estar disponível para a entrada de mais um navio. Assim, o navio entra no porto de Santos, percorrendo o canal de acesso, na distância desde a área de fundeio, até o berço que está disponível no momento. Já atracado no berço, o navio libera o canal de acesso para que outra embarcação possa utilizá-lo. De acordo com a capacidade do navio, 
que foi informada no momento do pedido de atracação, inicia-se o embarque da soja. No modelo foram utilizados dois tipos de navios: navios panamax com capacidade de carregar até 75.000 toneladas e navios capesize com capacidade de carregar até 200.000 toneladas de carga. A soja fica contida nos armazéns do porto e é transferida do armazém para o navio através de correia transportadora e shiploaders.

Quando o embarque da soja é finalizado, o navio aguarda até que o canal de acesso esteja disponível. Caso não esteja, ele aguarda atracado. Assim que desocupado o canal, o navio desatraca e segue para a saída do porto. Após sua saída, é liberado o canal de acesso e o modelo verifica as estatísticas geradas. As variáveis de saída são: tempo que o navio permaneceu na fila para entrar no canal de acesso, número médio de navios na fila, tempo de estadia do navio no porto, quantidade de soja movimentada e a quantidade de navios atendidos. No modelo não são consideradas restrições do tempo de operação na atracação dos navios, dado que o porto trabalha 24 horas por dia, sem intervalos.

\subsection{Limitações do modelo}

Durante o desenvolvimento do trabalho foi necessário assumir alguns pressupostos, que podem ser considerados limitações a uma aplicação mais ampla e geral do modelo. A seguir são comentados os pontos relevantes identificados:

- Quando um navio atraca, é assumido que toda a carga esteja disponível no armazém para embarque no navio, de modo que não haja espera para que chegue mais carga ao armazém.

- É assumido que todos os navios que entram no modelo, estão programados para atracar nas próximas 24 horas e assim esperam na área de fundeio apropriada. Existem outros cinco fundeadouros no Porto de Santos, porém não foram obtidos os dados relacionados às outras áreas, tais como: tempo médio de estadia, tempo médio de atracação, tempo médio de espera para atracação.

- Foram considerados somente dois tipos de navios para embarque de soja: navios panamax com capacidade de carregar até 75.000 toneladas e navios capesize com capacidade de carregar até 200.000 toneladas de carga. No modelo, é considerado que o navio panamax que chegar para embarque, será utilizada toda 
sua capacidade. Para os navios capesize foi adotada a capacidade de carregar 150.000 toneladas por limitações de profundidade no porto de Santos.

\subsection{Coleta de dados}

De acordo com Harrel et al. (2004), apud Castañon Guimarães (2008), a coleta de dados é um ponto muito importante para o processo de simulação. Se os dados forem consistentes, a coleta de dados faz com que o modelo também se torne consistente.

Para a elaboração e determinação do comportamento de cada uma das variáveis do modelo foram utilizados dados históricos do Porto de Santos disponibilizados no Mensário Estatístico da CODESP, e dados do Sistema de Informações Gerenciais divulgados pela ANTAQ, ambos do período de jan/2010 a jun/2012. Na seção 5.4 (Descrição do modelo) são mostrados todos os dados históricos relevantes para o desenvolvimento do modelo e como cada um destes dados foram inseridos no modelo, conforme descrito na seção 5.1 (Mapeamento do processo). Os dados analisados foram:

- Chegada de navios para embarque de soja no porto;

- Tempo médio de estadia;

- Tempo médio de atracação;

- Tempo médio de espera para atracação;

- Tempo médio de espera para início de operação;

- Percentual de chegada de cada tipo de navio ao porto (panamax ou capesize);

- Tempo médio de operação e tempo médio de desatracação.

\subsection{Descrição do Modelo}

Esse capítulo dedica-se à exposição e descrição do modelo de simulação construído utilizando o software Arena. Para um melhor entendimento, é importante que se comente algumas definições do ARENA.

Uma definição inicial e muito importante é a escolha da entidade que irá compor o modelo. As entidades representam um ou mais objetos que se movem pelo sistema. No caso em estudo, o navio e a carga representam as entidades do modelo. As filas são representadas pelas entidades que estão aguardando passar 
por algum módulo do sistema e por isso não seguem o fluxo normal do processo. As filas do modelo são: fila para a entrada no canal de acesso, fila para ocupação de berço de atracação e fila para a saída no canal de acesso. Os recursos são os elementos que atendem as entidades, e não se movimentam pelo modelo. Para a modelagem proposta são definidos como recursos: o espaço ocupado no canal de acesso e o atendimento em cada um dos três berços.

Para as informações estatísticas, o ARENA possui um banco de dados que guarda os dados relativos à simulação do modelo. Assim, por meio de seus relatórios disponibilizados ao final de cada rodada do modelo, é possível verificar e analisar os indicadores relativos aos processos, recursos e filas, com informações sobre tempo, utilização, custos e outros.

Os dados obtidos foram devidamente tratados e analisados através da utilização do software Statgraphics Centurion, versão 16.1.18. Esta ferramenta fornece ajustes estatísticos para um conjunto de dados experimentais, como os dados de entrada, de tempo de processo, entre outros. A partir de um conjunto de dados, o programa determina a melhor função que se ajusta a cada processo ou ainda pode-se escolher uma determinada função e determinar seus coeficientes. A seguir, uma descrição de cada um dos dados usados no modelo referente à operação dos navios.

- Chegada de navios para embarque de soja no porto:

Com o apoio dos dados extraídos do Sistema de Informações Gerenciais divulgados pela ANTAQ, foi analisada a curva de chegada dos navios no porto. Foi gerada uma curva de distribuição conforme mostra o Gráfico 3. Esta curva representa a chegada dos navios ao porto de Santos e que ficam esperando na área de fundeio destinada a eles.

O programa Statgraphics identifica a distribuição que melhor se adaptam ao processo chegada dos navios no porto, na Tabela 15. Os resultados da distribuição estatística, para o processo de chegadas, estão apresentados na Tabela 16, e a curva foi inserida no modelo para determinar a chegada dos navios. Por meio do teste Kolmogorov-Smirnov identificou a distribuição Lognormal a que apresenta melhor ajuste aos dados históricos. Para esta distribuição foi apresentado o $p$ value de 0,96 , conforme a Tabela 17 . De acordo com o relatório gerado pelo programa Statgraphics, é possível concluir que, desde que o menor valor de $p$ 
entre os testes realizados seja maior ou igual a 0,05, deve-se aceitar a hipótese de que os dados apresentam uma distribuição Lognormal, com 95\% de confiança.

Tabela 15 - Chegada de navios para embarque - Comparativo de Distribuições.

\begin{tabular}{|l|r|r|r|}
\hline Distribution & $\begin{array}{l}\text { Est. } \\
\text { Parameters }\end{array}$ & $\begin{array}{l}\text { Log } \\
\text { Likelihood }\end{array}$ & \\
\hline Lognormal & 2 & $-53,9103$ & 0,129303 \\
\hline Largest Extreme Value & 2 & $-53,9362$ & 0,135213 \\
\hline Gamma & 2 & $-54,1411$ & 0,148793 \\
\hline Loglogistic & 2 & $-54,2475$ & 0,138266 \\
\hline Uniform & 2 & $-54,3251$ & 0,345633 \\
\hline Weibull & 2 & $-55,1282$ & 0,156412 \\
\hline Logistic & 2 & $-55,2637$ & 0,151435 \\
\hline Normal & 2 & $-55,3776$ & 0,163469 \\
\hline Laplace & 2 & $-55,7799$ & 0,163801 \\
\hline Smallest Extreme Value & 2 & $-58,2626$ & 0,213051 \\
\hline Exponential & 1 & $-64,4561$ & 0,410792 \\
\hline Pareto & 1 & $-81,1665$ & 0,560419 \\
\hline
\end{tabular}

Tabela 16 - Chegada de navios para embarque - Distribuição ajustada.

\begin{tabular}{|l|}
\hline Lognormal \\
\hline mean $=27,1274$ \\
\hline standard deviation $=10,0211$ \\
\hline Log scale: mean $=3,23658$ \\
\hline Log scale: std. dev. $=0,35766$ \\
\hline
\end{tabular}

Tabela 17 - Chegada de navios para embarque - Teste Kolmogorov-Smirnov.

\begin{tabular}{|l|l|}
\hline & Lognormal \\
\hline DPLUS & 0,129303 \\
\hline DMINUS & 0,109475 \\
\hline DN & 0,129303 \\
\hline P-Value & 0,963438 \\
\hline
\end{tabular}




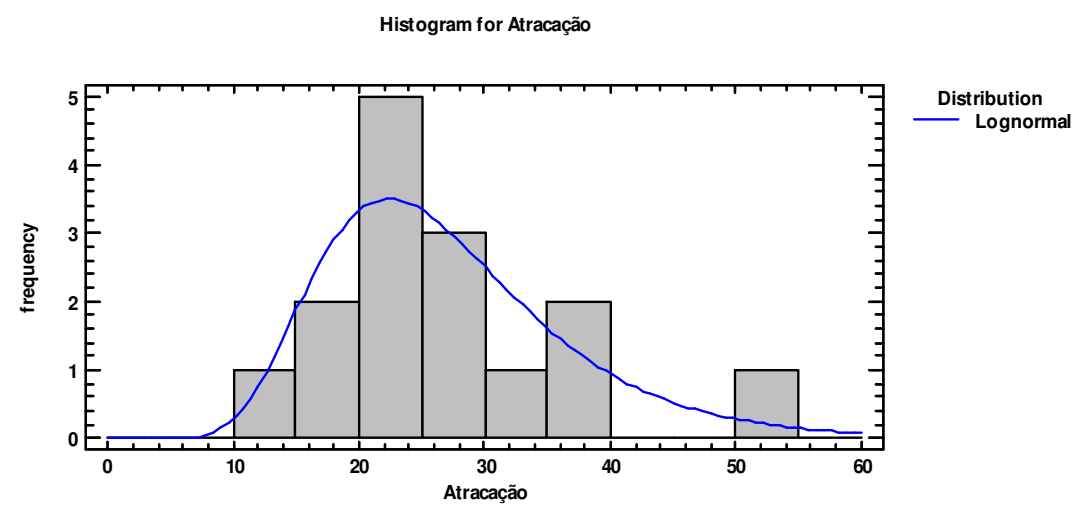

Gráfico 3 - Histograma da chegada de navios ao porto.

Assim, através do módulo de criação, serão gerados os navios segundo a distribuição estatística apresentada. No momento em que são gerados, os navios dirigem-se à estação Fundeio. Desta estação seguem para a estação Check Navio, onde é verificado se o navio que está entrando no sistema é um navio para embarque de soja. Com os dados disponíveis no mensário estatístico da CODESP, foi verificado que $4,4 \%$ dos navios que chegam ao porto de Santos são para embarque de soja. Portanto, somente esta proporção entrará no modelo e o percorrerá por completo.

- Tempo médio de espera para atracação:

Após a verificação da carga do navio descrita no item anterior, o navio segue para a estação Embarque, onde aguarda até a liberação para atracar (módulo Process). Segundo os dados do Sistema de Informações Gerenciais da ANTAQ, foi gerada pelo programa, a distribuição que melhor se adapta para o tempo de espera, na Tabela 18.

Tabela 18 - Tempo médio de espera para atracação.

\begin{tabular}{|l|r|r|r|}
\hline Distribution & $\begin{array}{l}\text { Est. } \\
\text { Parameters }\end{array}$ & $\begin{array}{l}\text { Log } \\
\text { Likelihood }\end{array}$ & \multicolumn{1}{l|}{ SSD } \\
\hline Lognormal & 2 & $-83,9532$ & 0,132506 \\
\hline Loglogistic & 2 & $-84,6242$ & 0,132992 \\
\hline Largest Extreme Value & 2 & $-84,6262$ & 0,155873 \\
\hline Normal & 2 & $-85,6853$ & 0,1611 \\
\hline Logistic & 2 & $-86,2346$ & 0,148114 \\
\hline Exponential & 1 & $-86,3984$ & 0,224063 \\
\hline Laplace & 2 & $-87,3091$ & 0,174188 \\
\hline Smallest Extreme Value & 2 & $-87,3507$ & 0,177881 \\
\hline Pareto & 1 & $-105,726$ & 0,511135 \\
\hline
\end{tabular}


O programa Statgraphics identificou a distribuição que melhor se adapta e, por meio do teste Kolmogorov-Smirnov, identificou a distribuição Lognormal a que apresenta melhor ajuste aos dados históricos pela Tabela 19. Para esta distribuição foi apresentado o p-value de 0,95, conforme a Tabela 20 e Gráfico 4.

Tabela 19 - Tempo médio de espera para atracação - Distribuição ajustada.

\begin{tabular}{|l|}
\hline Lognormal \\
\hline mean $=121,185$ \\
\hline standard deviation $=100,329$ \\
\hline Log scale: mean $=4,53631$ \\
\hline Log scale: std. dev. $=0,722505$ \\
\hline
\end{tabular}

Tabela 20 - Tempo médio de espera para atracação - Teste Kolmogorov-Smirnov.

\begin{tabular}{|l|l|}
\hline & Lognormal \\
\hline DPLUS & 0,119185 \\
\hline DMINUS & 0,132506 \\
\hline DN & 0,132506 \\
\hline P-Value & 0,954875 \\
\hline
\end{tabular}
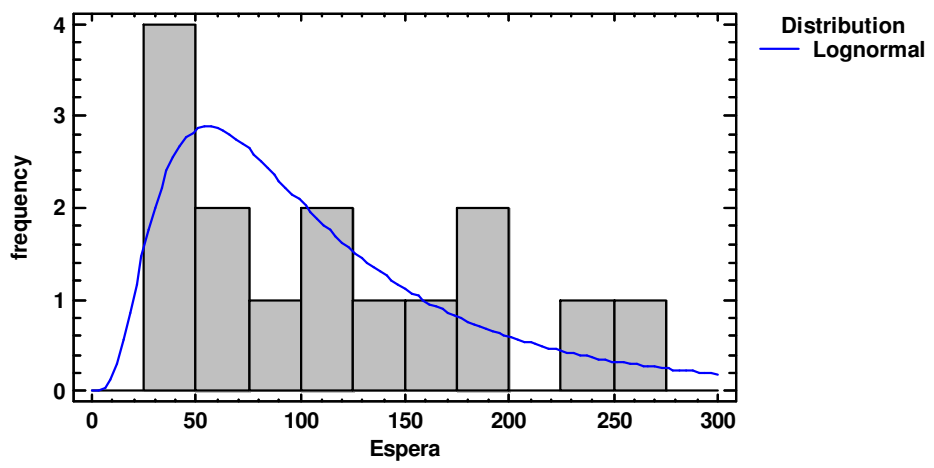

Gráfico 4 - Histograma do tempo médio de espera para atracação dos navios.

De acordo com o relatório gerado pelo programa Statgraphics, é possível concluir que, desde que o menor valor de $p$ entre os testes realizados seja maior ou igual a 0,05, deve-se aceitar a hipótese de que os dados apresentam uma distribuição Lognormal, com 95\% de confiança.

Depois de liberado para atracação, o navio passa para a estação Canal de Acesso, onde aguarda em fila para a utilização do recurso espaço canal. Este recurso representa a utilização do canal de acesso aonde é necessário aguardar pela liberação de um dos três berços de atracação.

Após a liberação do berço, o navio entra no porto, ocupando o recurso espaço canal durante a rota até o berço a que se destina. A escolha do berço de atracação é feita pelo do módulo Pickstation. Neste módulo, o modelo seleciona 
qual o berço que irá receber o navio, de acordo com a quantidade de recursos ocupados e a quantidade de navios indo para esta estação. Quando liberado um dos berços, o navio adentra o canal e, no mesmo instante, o navio já ocupa o recurso Embarque1, Embarque2 ou Embarque3, reservando-o para sua operação.

- Tempo médio de operação

Chegando à estação Berço (Berço1, Berço2 ou Berço3), o navio libera o recurso espaço canal, permitindo a navegação de outras embarcações. Posteriormente, o navio passa pelo módulo Decide Tipo Navio, onde é verificada a capacidade do navio, ou seja, se o navio é do tipo Panamax ou Capesize.

Para isto, foi utilizada uma aproximação dos dados apresentados por Juliá (2010), onde 53,3\% dos navios atendidos no porto são do tipo Panamax, o restante será do tipo Capesize. Neste trabalho apresentado por Juliá (2010), o porto considerado possui em um dos berços, o calado de 16 metros. Nas informações divulgadas à imprensa no portal do Porto de Santos, através de releases, o porto de Santos possui o projeto de aumentar o aprofundamento do canal passando para 15 metros de profundidade. Desta forma, foram considerados para o modelo desenvolvido, os dois tipos de navios: Panamax e Capesize.

O navio permanece atracado realizando as operações de carga e descarga, de acordo com a distribuição que melhor se adapta mostrada na Tabela 21.

Tabela 21 - Tempo médio de operações de carga e descarga.

\begin{tabular}{|l|r|r|r|}
\hline Distribution & $\begin{array}{l}\text { Est. } \\
\text { Parameters }\end{array}$ & $\begin{array}{l}\text { Log } \\
\text { Likelihood }\end{array}$ & \\
\hline Normal & 2 & $-55,8161$ & 0,183035 \\
\hline Laplace & 2 & $-56,0285$ & 0,146693 \\
\hline Logistic & 2 & $-56,0589$ & 0,162995 \\
\hline Gamma & 2 & $-56,1972$ & 0,201731 \\
\hline Birnbaum-Saunders & 2 & $-56,4557$ & 0,209718 \\
\hline Inverse Gaussian & 2 & $-56,4591$ & 0,20982 \\
\hline Lognormal & 2 & $-56,4779$ & 0,205269 \\
\hline Loglogistic & 2 & $-56,5783$ & 0,174849 \\
\hline Largest Extreme Value & 2 & $-57,5399$ & 0,213579 \\
\hline Exponential & 1 & $-78,366$ & 0,512535 \\
\hline Pareto & 1 & $-99,7662$ & 0,603177 \\
\hline
\end{tabular}


Tabela 22 - Tempo médio de operação - Distribuição ajustada.

Normal

mean $=68,3333$

standard deviation $=10,3343$

Tabela 23 - Tempo médio de operação - Teste Kolmogorov-Smirnov.

\begin{tabular}{|l|l|}
\hline & Normal \\
\hline DPLUS & 0,0928407 \\
\hline DMINUS & 0,183035 \\
\hline DN & 0,183035 \\
\hline P-Value & 0,696389 \\
\hline
\end{tabular}

O programa Statgraphics identifica a distribuição que melhor se adapta e, por meio do teste Kolmogorov-Smirnov, identificou a distribuição Normal a que apresenta melhor ajuste aos dados históricos do Sistema de Informações Gerenciais da ANTAQ, na Tabela 22. Para esta distribuição foi apresentado o $p$ value de 0,69 , conforme Tabela 23 e Gráfico 5.

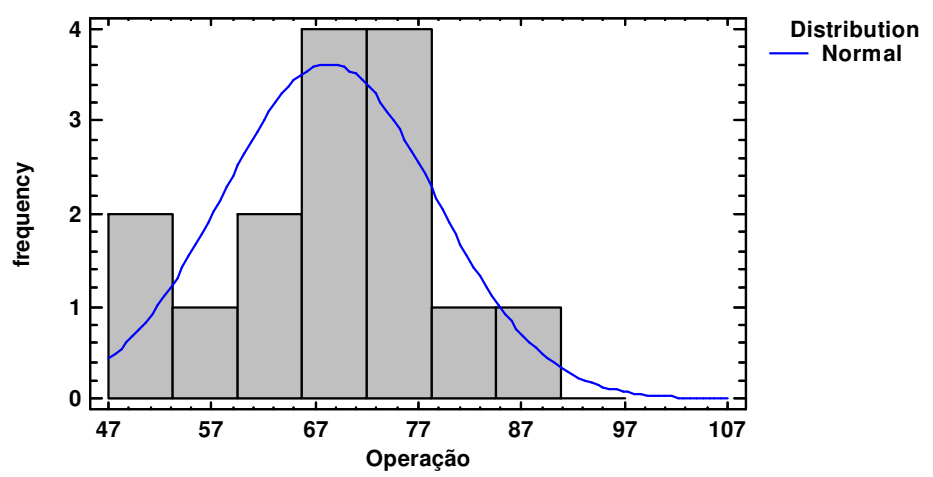

Gráfico 5 - Histograma do tempo médio de operação de embarque de soja.

Ao final da operação de embarque, o navio então libera o recurso berço em que está atracado e aguarda pela liberação do recurso espaço canal para deixar o porto. Quando o canal encontra-se livre, o navio o percorre com tempo de navegação (Delay Time), que foi calculado a partir da distância do berço à saída do porto e a velocidade média dos navios, e em rota, segue rumo à estação Saída Navio do porto (que equivale fisicamente à entrada do porto). 


\subsection{Aplicação do Modelo}

\subsubsection{Verificação e Validação do Modelo}

A verificação e a validação das modelagens propostas são de extrema importância para a análise dos resultados apresentados. Para o desenvolvimento do modelo de simulação deve-se estar seguro de que o mesmo esteja sendo

corretamente implementado. É pressuposto que o modelo não apresenta erros de sintaxe e lógica e, assim, podendo ser uma aproximação do sistema real.

Segundo Freitas Filho (2001), a qualidade e a validade de um modelo de simulação são medidas pela proximidade entre os resultados obtidos pelo modelo e aqueles que têm origem do sistema real. Como o modelo apresenta suposições e simplificações do sistema real, deve-se avaliar se os resultados obtidos estão de acordo com o sistema real e se as decisões tomadas a partir destes resultados são consistentes. É importante avaliar se mesmo com as simplificações adotadas no modelo, é possível supor que o modelo é valido.

Durante o desenvolvimento do modelo de simulação foi incluída a participação de especialistas de operações portuárias, que contribuíram com suas considerações. Harrel et al. (2004) apud Castañon Guimarães (2008), julgam necessário o envolvimento de especialistas que possuem conhecimento sobre o sistema real que será modelado. Neste modelo, apesar de existirem algumas aproximações que serão descritas a seguir e as limitações já mencionadas, a modelagem foi considerada válida pelos especialistas, pois apresenta aproximação com o sistema real.

\subsubsection{Tamanho das replicações e número de replicações}

No modelo foram utilizados os dados no período de safra de janeiro de 2010 a junho de 2012. A replicação do modelo representa o período de tempo em que uma simulação será gerada. Para o presente trabalho, o tamanho da replicação foi o mesmo que o período que a safra da soja é escoada no porto, ou seja, por cinco meses, correspondente a 3.600 horas. Este período foi escolhido pelo fato de no período de safra da soja é quando se apresenta os maiores problemas de congestionamento no porto. Além disso, a versão Student do software Arena não permite que o modelo rode com mais de 150 entidades. Se fossem utilizados 
dados para todos os meses do ano por três anos seguidos, por exemplo, o modelo ultrapassaria o limite de entidades.

O número de replicações é uma repetição da simulação do modelo, com a mesma configuração, a mesma duração e com os mesmos parâmetros de entrada, mas com uma geração de números aleatórios diferentes. Apesar de os dados e os parâmetros de entrada ser os mesmos, como são números aleatórios, para cada replicação terá uma saída diferente. Os dados de entrada do modelo são baseados em curvas estatísticas retiradas dos dados históricos do porto e, devido aos desvios estatísticos adotados, os resultados de cada replicação serão diferentes.

Para determinar qual o número suficiente de replicações para que se tenha consistência estatística dos resultados, foi aplicado o critério sugerido por Prado (2010). No presente trabalho foram escolhidas variáveis chaves como o total de navios atendidos. O critério adotado para a determinação do número de replicações foi definido como a escolha da replicação em que se obtivesse pela terceira vez consecutiva o mesmo valor da média para a variável. Foram rodadas 25 replicações, sendo que cada replicação consiste em um período de cinco meses.

A partir dos indicadores de desempenho e das distribuições citadas anteriormente, foram analisados três cenários. A seguir, as considerações pertinentes a cada cenário:

Cenário base - Este é o cenário base, onde não há nenhuma mudança no porto e todo o sistema que o engloba.

Cenário 1 - Foram realizadas duas variações deste cenário, chamadas de cenário $1 \mathrm{~A}$ e cenário $1 \mathrm{~B}$. O cenário $1 \mathrm{~A}$ considerou o porto operando com um berço a mais, operando com quatro berços no total. Para o cenário 1B foram considerados cinco berços no sistema.

Cenário 2 - Para este cenário foram realizadas duas variações, chamadas de cenário $2 \mathrm{~A}$ e cenário $2 \mathrm{~B}$. Com a ocorrência de chuvas, o embarque da soja deve ser paralisado para que a carga não seja danificada. Para este cenário foram analisadas as operações com menor ocorrência de chuvas (2A) e maior ocorrência de chuvas (2B). 


\subsubsection{Cenário base}

Para o cenário inicial foram utilizadas as distribuições já mencionadas anteriormente, assim como o percentual do tipo de navio que chega ao porto, e foram considerados os três berços do cais público. Para este cenário os dados foram gerados de acordo com as Tabelas 24 e 25.

Tabela 24 - Cenário base: resultados.

\begin{tabular}{|l|r|}
\hline \multicolumn{2}{|c|}{ Cenário Base } \\
\hline Total de chegada de navios & 2.544 \\
\hline Total de navios de soja & 104 \\
\hline Tempo médio na fila do canal de acesso (h) & 29,0 \\
\hline Tempo médio na fila do canal de acesso na volta (h) & 37,0 \\
\hline Número médio de atendimento no canal de acesso & 0,45 \\
\hline Total de navios Panamax atendidos pelos três berços & 46 \\
\hline Total de navios Capesize atendidos pelos três berços & 4.275 .000 \\
\hline Total de carga movimentada (t) - Panamax & 6.900 .000 \\
\hline Total de carga movimentada (t) - Capesize & 11.175 .000 \\
\hline Total de carga movimentada (t) & \\
\hline
\end{tabular}

Tabela 25 - Cenário base: Total de carga movimentada por berços.

\begin{tabular}{|l|r|r|r|}
\hline \multicolumn{1}{|c|}{ Cenário Base } & \multicolumn{1}{c|}{ Berço 1 } & \multicolumn{1}{c|}{ Berço 2 } & \multicolumn{1}{c|}{ Berço 3 } \\
\hline Total de navios atendidos & 46 & 32 & 25 \\
\hline Total de navios Panamax & 30 & 14 & 13 \\
\hline Total de navios Capesize & 16 & 18 & 12 \\
\hline Número médio de atendimento no embarque & 0,85 & 0,61 & 0,46 \\
\hline
\end{tabular}

Para o cenário base, entraram no modelo 2.544 navios e foram atendidos 104 navios de soja. Como se pode observar, o tempo médio de espera na fila do canal de acesso tanto da entrada no porto, quanto para sair, é muito alto, acarretando assim, em multa sobre atrasos no atendimento dos navios.

A partir destes resultados verifica-se que o modelo reproduz uma aproximação do sistema real, dado que no ano de 2010, para o mesmo período aplicado à modelagem, atracou no Porto de Santos o total de 2.282 navios, sendo 
195 navios de soja. Em 2011, atracou o total de 2.341 navios, sendo 215 navios de soja (Dados Mensário Estatístico CODESP, 2010 e 2011).

\subsubsection{Cenário $1 \mathrm{~A}$}

Para este novo cenário foi considerada a instalação de mais um berço de atracação no cais público para a operação de grãos. Isto acarretaria a diminuição do congestionamento do porto, principalmente no período de safra da soja brasileira. Para este cenário os dados foram gerados de acordo com as Tabelas 26 e 27.

Tabela 26 - Cenário 1A: resultados.

\begin{tabular}{|l|r|}
\hline \multicolumn{2}{|c|}{ Cenário 1A } \\
\hline Total de chegada de navios & 2.527 \\
\hline Total de navios de soja & 110 \\
\hline Tempo médio na fila do canal de acesso (h) & 16,8 \\
\hline Tempo médio na fila do canal de acesso na volta (h) & 20,8 \\
\hline Número médio de atendimento no canal de acesso & 0,26 \\
\hline Total de navios Panamax atendidos pelos três berços & 44 \\
\hline Total de navios Capesize atendidos pelos quatro berços & 4.800 .000 \\
\hline Total de carga movimentada (t) - Panamax & 6.600 .000 \\
\hline Total de carga movimentada (t) - Capesize & 11.400 .000 \\
\hline Total de carga movimentada (t) & \\
\hline
\end{tabular}

Tabela 27 - Cenário 1A: Total de carga movimentada por berços.

\begin{tabular}{|l|r|r|r|r|}
\hline \multicolumn{1}{|c|}{ Cenário 1A } & \multicolumn{1}{|c|}{ Berço 1 } & \multicolumn{1}{c|}{ Berço 2 } & \multicolumn{1}{c|}{ Berço 3 } & \multicolumn{1}{c|}{ Berço 4 } \\
\hline Total de navios atendidos & 31 & 21 & 16 & 40 \\
\hline Total de navios Panamax & 19 & 11 & 9 & 25 \\
\hline Total de navios Capesize & 12 & 10 & 7 & 15 \\
\hline Número médio de atendimento no embarque & 0,58 & 0,40 & 0,31 & 0,77 \\
\hline
\end{tabular}

Observou-se uma diminuição nos tempos de espera para entrada do canal de acesso, assim como na saída do canal quando comparado com o cenário base. Os 
atendentes nos berços apresentaram melhora nos indicadores de atendimento e o número de navios Panamax atendidos foi maior neste cenário.

\subsubsection{Cenário 1B}

Neste cenário foi sugerida a instalação de mais outro berço de atracação com o intuito de atender um número maior de navios, tendo no total cinco berços no cais. Os resultados são apresentados nas Tabelas 28 e 29.

Tabela 28 - Cenário 1B: resultados.

\begin{tabular}{|l|r|}
\hline \multicolumn{2}{|c|}{ Cenário 1B } \\
\hline Total de chegada de navios & 2.533 \\
\hline Total de navios de soja & 110 \\
\hline Tempo médio na fila do canal de acesso (h) & 2,2 \\
\hline Tempo médio na fila do canal de acesso na volta (h) & 3,3 \\
\hline Número médio de atendimento no canal de acesso & 0,09 \\
\hline Total de navios Panamax atendidos pelos três berços & 44 \\
\hline Total de navios Capesize atendidos pelos cinco berços & 4.875 .000 \\
\hline Total de carga movimentada (t) - Panamax & 6.600 .000 \\
\hline Total de carga movimentada (t) - Capesize & 11.475 .000 \\
\hline Total de carga movimentada (t) & \\
\hline
\end{tabular}

Tabela 29 - Cenário 1B: Total de carga movimentada por berços.

\begin{tabular}{|l|r|r|r|r|r|}
\hline \multicolumn{1}{|c|}{ Cenário 1B } & \multicolumn{1}{|c|}{ Berço 1 } & \multicolumn{1}{c|}{ Berço 2 } & \multicolumn{1}{c|}{ Berço 3 } & \multicolumn{1}{c|}{ Berço 4 } & \multicolumn{1}{c|}{ Berço 5 } \\
\hline Total de navios atendidos & 21 & 12 & 7 & 32 & 37 \\
\hline Total de navios Panamax & 10 & 7 & 4 & 17 & 27 \\
\hline Total de navios Capesize & 11 & 5 & 3 & 15 & 10 \\
\hline Número médio de atendimento no embarque & 0,40 & 0,24 & 0,15 & 0,62 & 0,71 \\
\hline
\end{tabular}

No cenário 1B, os tempos de espera para a passagem dos navios no canal de acesso diminuem consideravelmente em relação ao cenário base, onde o berço 5 proposto foi utilizado com $71 \%$ de sua capacidade. 


\subsubsection{Cenário 2}

Neste cenário foi verificada a operação do porto com ocorrência de chuvas. Nas informações divulgadas à imprensa no portal do Porto de Santos, através de releases, um dos principais gargalos logísticos é a chuva, que pode interromper a operação do porto por até 90 dias no ano.

Os granéis são os produtos mais sensíveis e, por isso, para o embarque, os porões dos navios devem estar completamente secos, pois, em caso de umidade, eles podem apodrecer e perder completamente sua utilidade. Com a ocorrência de chuvas, os navios são obrigados a esperar e provocam congestionamentos tanto de navios quanto de caminhões no Complexo Santista. Assim, foi estimado por meio dos dados de precipitações na cidade de Santos, obtidos pela Somar Meteorologia, o percentual de ocorrência de chuvas durante todos os meses do ano.

Para o cenário $2 \mathrm{~A}$, foi definido que para os meses que chovem até $5 \%$ do total de chuvas no ano, são os meses que menos afetam a operação devido às chuvas. No cenário 2B, os meses com maior incidência de chuvas (acima de 5\%), mais impactam na operação de embarque de soja. Para os dois cenários, foram considerados os três berços atuais do porto.

\subsubsection{Cenário $2 \mathrm{~A}$}

Neste cenário foi analisada a operação do porto nos meses com menor incidência de chuvas. Seguem os resultados nas Tabelas 30 e 31 . 
Tabela 30 - Cenário 2A: resultados.

\begin{tabular}{|l|r|}
\hline \multicolumn{2}{|c|}{ Cenário 2A } \\
\hline Total de chegada de navios & 2.018 \\
\hline Total de navios de soja & 91 \\
\hline Tempo médio na fila do canal de acesso (h) & 10,8 \\
\hline Tempo médio na fila do canal de acesso na volta (h) & 14,6 \\
\hline Número médio de atendimento no canal de acesso & 0,27 \\
\hline Total de navios Panamax atendidos pelos três berços & 32 \\
\hline Total de navios Capesize atendidos pelos três berços & 4.350 .000 \\
\hline Total Panamax & 4.800 .000 \\
\hline Total Capesize & 9.150 .000 \\
\hline Total de carga movimentada (t) & \\
\hline
\end{tabular}

Tabela 31 - Cenário 2A: Total de carga movimentada por berços.

\begin{tabular}{|l|r|r|r|}
\hline \multicolumn{1}{|c|}{ Cenário 2A } & \multicolumn{1}{|c|}{ Berço 1 } & \multicolumn{1}{c|}{ Berço 2 } & \multicolumn{1}{c|}{ Berço 3 } \\
\hline Total de navios atendidos & 41 & 27 & 22 \\
\hline Total de navios Panamax & 23 & 20 & 15 \\
\hline Total de navios Capesize & 18 & 7 & 7 \\
\hline Número médio de atendimento no embarque & 0,78 & 0,55 & 0,42 \\
\hline
\end{tabular}

\subsubsection{Cenário 2B}

Neste cenário foi analisada a operação do porto nos meses com maior incidência de chuvas. Os resultados são apresentados nas Tabelas 32 e 33. 
Tabela 32 - Cenário 2B: resultados.

\begin{tabular}{|l|r|}
\hline \multicolumn{2}{|c|}{ Cenário 2B } \\
\hline Total de chegada de navios & 1.929 \\
\hline Total de navios de soja & 90 \\
\hline Tempo médio na fila do canal de acesso (h) & 12,0 \\
\hline Tempo médio na fila do canal de acesso na volta (h) & 14,9 \\
\hline Número médio de atendimento no canal de acesso & 0,21 \\
\hline Total de navios Panamax atendidos pelos três berços & 31 \\
\hline Total de navios Capesize atendidos pelos três berços & 4.125 .000 \\
\hline Total de carga movimentada (t) - Panamax & 4.650 .000 \\
\hline Total de carga movimentada (t) - Capesize & 8.775 .000 \\
\hline Total de carga movimentada (t) & \\
\hline
\end{tabular}

Tabela 33 - Cenário 2B: Total de carga movimentada por berços.

\begin{tabular}{|l|r|r|r|}
\hline \multicolumn{1}{|c|}{ Cenário 2B } & \multicolumn{1}{|c|}{ Berço 1 } & \multicolumn{1}{|c|}{ Berço 2 } & \multicolumn{1}{c|}{ Berço 3 } \\
\hline Total de navios atendidos & 40 & 28 & 18 \\
\hline Total de navios Panamax & 28 & 19 & 8 \\
\hline Total de navios Capesize & 12 & 9 & 10 \\
\hline Número médio de atendimento no embarque & 0,70 & 0,51 & 0,31 \\
\hline
\end{tabular}

No cenário 2B (com maior ocorrência de chuvas), é possível observar o aumento do tempo médio na fila para o canal de acesso, acarretando na espera do navio para ser embarcada a soja. Quando o cenário 2B, comparado com o cenário base, verifica-se que o número de navios atendidos foi reduzido, passando de 103 navios para 86 navios atendidos no cenário com chuvas.

O total de carga movimentada também reduziu. No cenário base o total movimentado foi de 11.175.000 toneladas, enquanto no cenário $2 \mathrm{~B}$, foi de 8.775.000 toneladas. Isto confirma o comportamento do sistema portuário quando submetido a mudanças climáticas e à redução de carga movimentada pelo porto.

Para o caso das chuvas, seria interessante a implantação de coberturas como a utilizada no porto de Roterdã, na Holanda, que utiliza uma estrutura de 
cobertura, para embarque de papel e celulose, que envolve todo o porão do navio, protegendo a carga das chuvas. A estrutura também ajuda a eliminar a poeira do embarque e diminui a poluição no entorno da área portuária. Com isto, os embarques não enfrentariam os atrasos provocados pelas chuvas, e seria possível a movimentação contínua da carga no porto de Santos. 


\section{Conclusão}

Este trabalho teve como objetivo apresentar e analisar as principais características do complexo soja. A soja é um produto de grande importância para o país, sendo a principal cultura explorada no mercado interno, além de ter expressiva participação nas exportações brasileiras e apresentar crescente produção e consumo, tanto no mercado nacional como internacional.

Para o processo de escolha do modal de transporte, deve ser considerado o que melhor atende às características do mercado, carga a ser transportada, legislação vigente, infraestrutura de transportes e tecnologia. Como foi analisado neste trabalho, o modal rodoviário apresenta uma participação expressiva na atual matriz de transporte de cargas brasileiras, incluindo os escoamentos de soja para exportação. Como a soja é um produto de baixo valor agregado, é importante que sua produção, estocagem, transporte e armazenagem tenham seus processos otimizados. Pelo fato dos custos de transporte ter grande participação na composição dos custos logísticos, estes influenciam no resultado final do produtor. Portanto, a redução do custo de transporte e o escoamento eficiente de safras são importantes para a manutenção da competitividade do agronegócio brasileiro.

Os portos são fundamentais para que o escoamento dos grãos seja eficiente e tenha competitividade no comércio internacional. A operação portuária é uma atividade complexa, exige integração logística e abrange diversos serviços desde a chegada do navio no porto, seu atracamento, o transbordo de cargas e saída do navio para um novo destino.

Visando alcançar o objetivo traçado neste trabalho, foi realizada uma análise da operação do Porto de Santos, em termos de congestionamento, por meio dos dados de movimentação de navios e carga. Os dados obtidos foram devidamente tratados e analisados pela utilização do software Statgraphics Centurion, versão 16.1.18. Foram identificados os problemas enfrentados na operação portuária e usando a técnica de simulação, utilizando o software Arena, versão 12.0, foi possível comparar os resultados obtidos com os dados reais observados.

Para o modelo proposto foram considerados dados reais e os resultados obtidos se aproximam da realidade estudada, apesar das simplificações adotadas. A execução do modelo de simulação utilizando o software Arena gerou resultados 
coerentes comparáveis à realidade a respeito do funcionamento operacional do sistema, permitindo apoio ao planejamento e às decisões futuras da operação.

No primeiro momento foi gerado o cenário base, com a operação do porto funcionando com os três berços já existentes. Com o objetivo de diminuir o tempo de espera na fila de acesso ao porto, para o primeiro cenário foi sugerido à inclusão de mais um berço na estrutura do porto. Como resultado, o tempo de espera para acessar o canal do porto diminuiu $42 \%$ em relação ao cenário base e o total de carga movimentada aumentou $2 \%$. Além disso, foi verificado que, com a utilização de mais outro berço (total de cinco berços), o tempo de espera para acessar o canal diminui em $87 \%$, e a carga movimentada aumentou $3 \%$, em comparação com o cenário base.

Para o segundo cenário proposto, é analisado a ocorrência de chuvas no Porto de Santos. As chuvas fazem com que a operação do porto deixe de funcionar mais de 90 dias por ano, obrigando os navios a esperar, provocando congestionamentos. Foi verificado no modelo de simulação que, com maior incidência de chuvas, a movimentação de soja diminui consideravelmente (21\%) em relação ao cenário base. Deste modo, é sugerida a instalação de uma cobertura de tecido especial retrátil que pode ser acionada em dias de chuva, semelhante à utilizada no porto de Roterdã, que protege a carga das chuvas e evita a parada na operação de embarque de soja.

Ambos os cenários apresentam melhorias na operação do cais público do porto de Santos. Tendo em vista o crescimento da demanda de exportações, com destaque para a soja, investimentos na infraestrutura do porto são essenciais para que o porto consiga atender as expectativas futuras, e não atinja a saturação.

\subsection{Trabalhos futuros}

São sugeridos alguns pontos que podem ser objeto de estudo de trabalhos futuros e que preenchem algumas lacunas deste trabalho:

- Incorporar um estudo de localização para determinar o local onde deverão ser instalados um ou dois berços de atracação.

- Desenvolver o modelo considerando todos os meses do ano e acrescentar outros granéis. 
- Acrescentar os tempos de manobra de atracação, manobra de desatracação, tempo de aguardo de maré para desatracação e cálculos de demurrage. 


\section{Referências bibliográficas}

ABIOVE - Associação Brasileira de Indústrias de Óleos Vegetais. Estatísticas do complexo da soja. Disponível em:

$<$ http://www.abiove.com.br > Acesso: setembro 2011.

ABTP - Associação Brasileira dos Terminais Portuários. Relatório anual 2011. Disponível em:

<http://www.abiove.com.br > Acesso: março 2012.

ANTT - Agência Nacional de Transportes Terrestres. Disponível em: <http://www.antt.gov.br> Acesso em: maio 2011.

ANTAQ - Agência Nacional de Transportes Aquaviário. Desempenho Portuário. Disponível em:

<http://www.antaq.gov.br/Portal/DesempenhoPortuario/Index.asp> Acesso em: maio 2012.

BALLOU, R.H. Logística empresarial: transportes, administração de materiais e distribuição física. São Paulo: Atlas, 1995

BIAGGIONI, M.A.M.; BOVOLENTA, F.C. Balanço energético comparativo para rotas de escoamento de soja. Eng. Agríc., Jaboticabal, v.30, n.4, p.587-599, jul./ago. 2010.

BRASIL. Ministério do Desenvolvimento, Indústria e Comércio Exterior. Alice Web 2. Disponível em:

<http://aliceweb2.mdic.gov.br/> Acesso em: junho 2012.

BUENO DA COSTA, M.A. Simulação de Sistemas, 2002. Disponível em: < www.simucad.dep.ufscar.br> Acesso: maio 2011.

BULHÕES, R.; CAIXETA-FILHO,J.V. Análise da distribuição logística da soja na região centro-sul do Brasil através de um modelo de equilíbrio espacial. Teor. Evid. Econ., Passo Fundo, v. 8, n. 15, p. 11-23, nov. 2000.

CAIXETA-FILHO,J.V.; MARTINS,R. Gestão Logística do transporte de cargas. São Paulo: Ed. Atlas, 2010.

CASTAÑON GUIMARÃES, A.M. Empresas de gestão conservadora: potencial da previsão de demanda e simulação computacional. Dissertação (Mestrado em Engenharia Industrial). Pontifícia Universidade Católica do Rio de Janeiro, Rio de Janeiro, 2008. 
CNT - Confederação Nacional dos transportes. Plano CNT de Logística, 2011. Disponível em:

<http://www.cnt.org.br> Acesso em: maio 2011.

. Pesquisa CNT de Rodovias, 2011. Disponível em:

<http://www.cnt.org.br> Acesso em: maio 2011.

. Transporte de Cargas no Brasil, 2000. Disponível em:

<www.cnt.org.br> Acesso em: maio 2011.

CODESP - Companhia Docas do Estado de São Paulo. Disponível em: <www.portodesantos.com.br/> Acesso em: julho 2012.

. Desenvolvimento do Porto de Santos, 2009. Disponível em:

<http://www.sinaenco.com.br/downloads/Codesp.pdf> Acesso em: maio 2011.

. Mensário Estatístico. Disponível em:

<http://www.portodesantos.com.br/estatisticas.php> Acesso em: maio 2011.

. Plano de Expansão do Porto, 2010. Disponível em:

<http://www.portodesantos.com.br > Acesso em: maio 2011.

. Relatório anual 2011. Disponível em:

<www.portodesantos.com.br> Acesso em: junho 2012.

. Regulamento de exploração do Porto de Santos. Disponível em:

< www.portodesantos.com.br> Acesso em: maio 2011.

CONAB - Companhia Nacional de Abastecimento. Acompanhamento de safra brasileira: grãos, décimo segundo levantamento, 2012 Disponível em:

<http://www.conab.gov.br> Acesso em: setembro 2012.

DNIT - Departamento Nacional dos Transportes. Disponível em: <http://www.dnit.gov.br> Acesso em: julho 2011.

DUBKE, A.F. Modelo de localização de terminais especializados: um estudo de caso em corredores de exportação da soja. Tese de doutorado. Rio de Janeiro: PUC-Rio, Departamento de Engenharia Industrial, 2006.

EMBRAPA - Empresa Brasileira de Pesquisa Agropecuária. Disponível em:

< http://www.embrapa.gov.br > Acesso em: julho 2011.

em:

. O complexo agroindustrial da soja brasileira, 2007. Disponível

< http://www.embrapa.gov.br > Acesso em: julho 2011. 
FLEURY, P.F. Gestão Estratégica do Transporte, 2002. Disponível em: $<$ http://ilos.com.br> Acesso em: julho 2011.

FREITAS FILHO, P. J. Introdução à modelagem e simulação de sistemas. Florianópolis: Visual Books, 2001.

GOEBEL, D. A competitividade externa e a logística doméstica. In: O desafio das exportações. BNDES. 1 ed. Rio de Janeiro. 2002

ILOS - Instituto de Logística e Supply Chain, Panorama das ferrovias brasileiras - Brasil, 2009. Disponível em:

$<$ http://ilos.com.br> Acesso em: julho 2011.

JULIÁ, A. F.; Desenvolvimento de um modelo de simulação para dimensionamento de um sistema integrado pátio-porto na cadeia do minério de ferro. Dissertação (Mestrado Interdepartamental em Engenharia de Sistemas Logísticos). Escola Politécnica da Universidade de São Paulo, São Paulo, 2010.

LAZZARINI, S. G.; NUNES, R. Competitividade do sistema agroindustrial da soja. Programa de Estudo dos Negócios dos Sistemas Agroindustriais, Pensa, 2000.

LíCIO, A.; CORBUCCI, R. A agricultura e os corredores de transporte multimodais. Revista de Política Agrícola, v. 5, n.2, p.22-36, 1996.

MALIGO, C. Modelo para simulação da operação de carregamento de caminhões-tanques em uma base de distribuição de combustíveis automotivos. Dissertação (Mestrado em Engenharia Industrial). Pontifícia Universidade Católica do Rio de Janeiro, Rio de Janeiro, 2005.

MAPA - Ministério da agricultura, pecuária e abastecimento. Brasil projeções do agronegócio 2011/2012 a 2021/2022, 2012. Disponível em:

< http://www.embrapa.gov.br > Acesso em: julho 2011.

NOVAES, A. G. Logística e gerenciamento da cadeia de distribuição. 2ed. Rio de Janeiro: Elsevier, 2007.

OJIMA,A.L.R.O. Análise da movimentação logística e competitividade da soja brasileira: uma aplicação de um modelo de equilíbrio espacial de programação quadrática. Dissertação (Mestrado em Engenharia Elétrica). Programa de Pós-graduação em Engenharia Elétrica, Universidade Estadual de Campinas, Campinas, 2004.

Perfil da logística de transporte de soja no Brasil. Informações Econômicas, São Paulo, n.16, jan. 2006.

PARAGON. Página eletrônica. Disponível em: 
<www.workforce.com.br> Acesso em: dezembro 2011.

PRADO, Darci. Usando o Arena em Simulação. Belo Horizonte, INDG Tecnologia e Serviços, 2010.

SALIBY, E.; LARA, M. S.; LACERDA, L.; NAZARIO, P.R.S. Modelo de Simulação de Operações Portuárias. In: IX CLAIO, 1998, Buenos Aires. Anais do IX CLAIO, 1998.

SECEX - Secretaria de Comércio Exterior. Ministério do Desenvolvimento, Indústria e Comércio, Balança comercial brasileira dados consolidados, 2011. Disponível em:

<http:www.desenvolvimento.gov.br > Acesso em: junho 2012.

USDA - United States Departoneladaent of Agriculture. Disponível em: <http://www.usda.gov> Acesso em: julho 2011.

WANKE, P. F.; HIJJAR, M. F. Exportadores Brasileiros: Estudo Exploratório das Percepções sobre a Qualidade da Infraestrutura Logística. Produção, v. 19, n. 1, p. 143-162, 2009. 


\section{Apêndice}

\subsection{Codificação do modelo no Arena}

É apresentada a seguir a codificação do modelo no Arena. Trata-se da apresentação dos blocos que formam a lógica do modelo. Para os cenários base e cenário 2 foram utilizados os blocos a seguir:

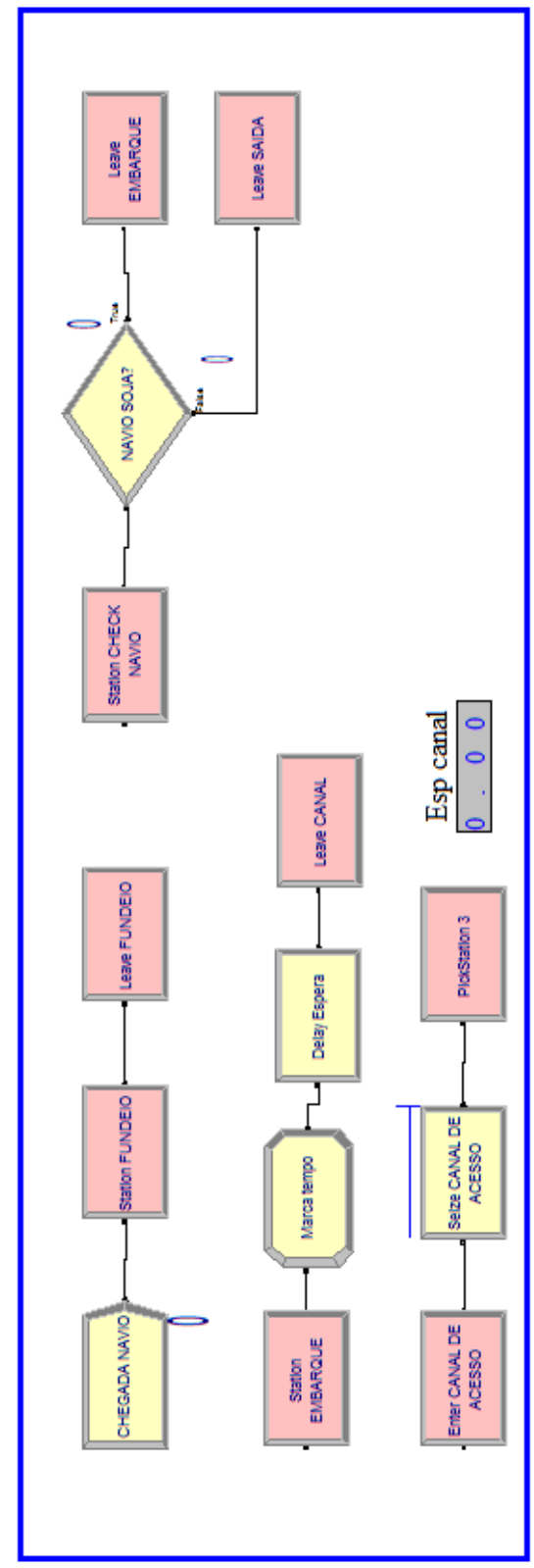

Figura 17 - Chegada de navios de soja, espera para o canal de acesso e escolha do berço (pickstation). 


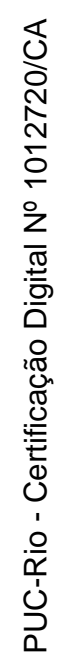

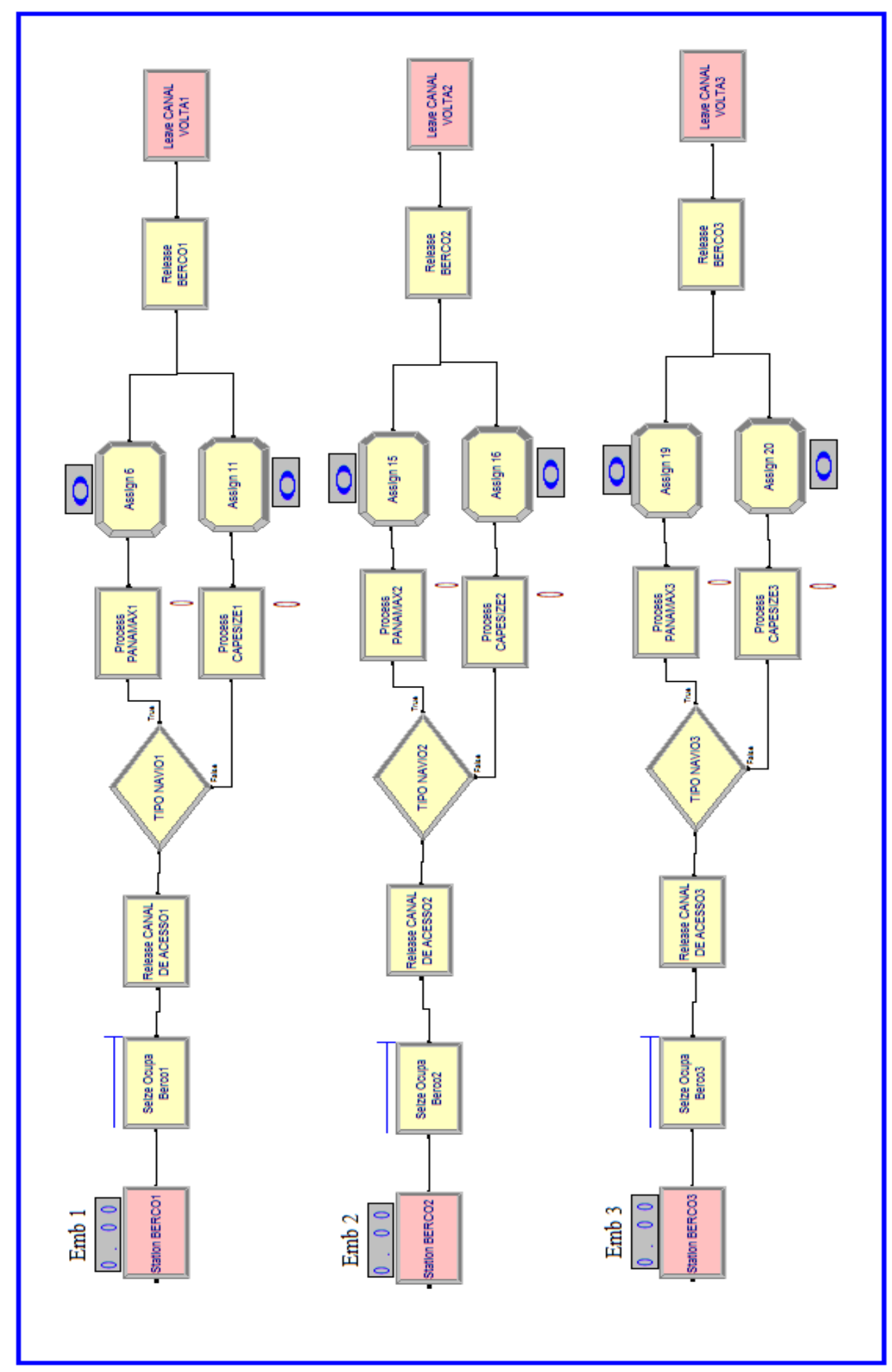

Figura 18 - Berços de atracação dos navios e processo de carregamento. 


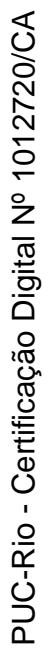

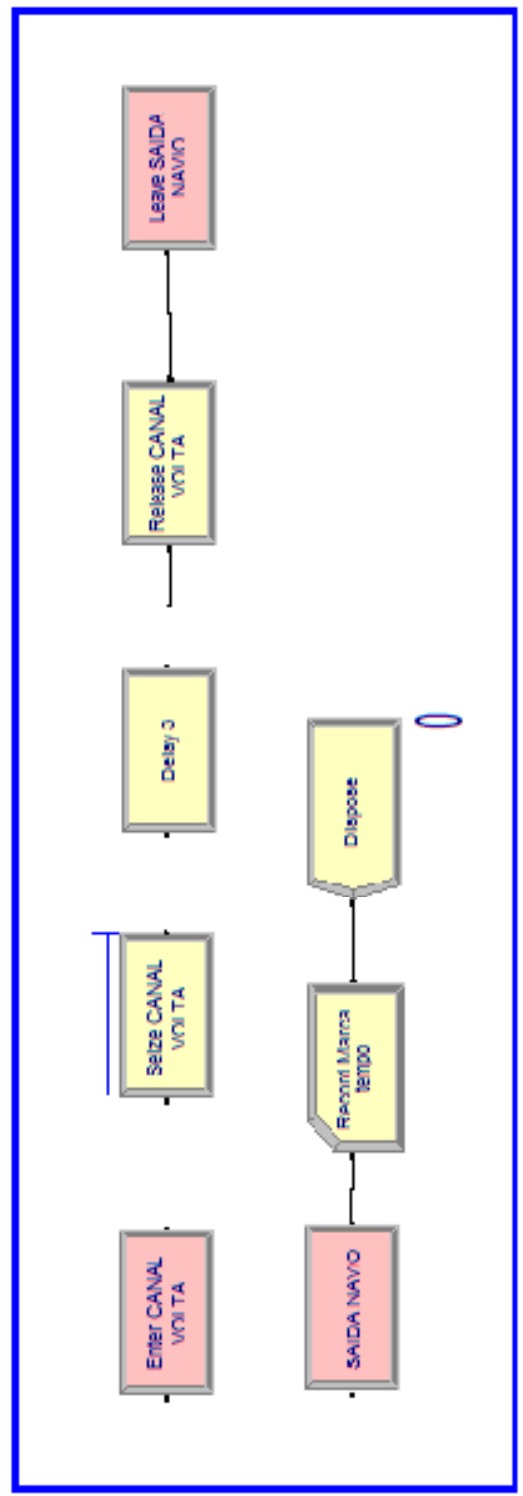

Figura 19 - Entrada no canal de acesso para a volta e saído do porto. 
Para o cenário 1A e 1B os blocos dos berços de atracação dos navios e processo de carregamento foram alterados. Segue a codificação do modelo:

- Cenário 1A:

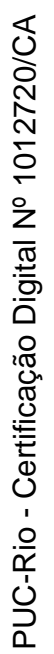

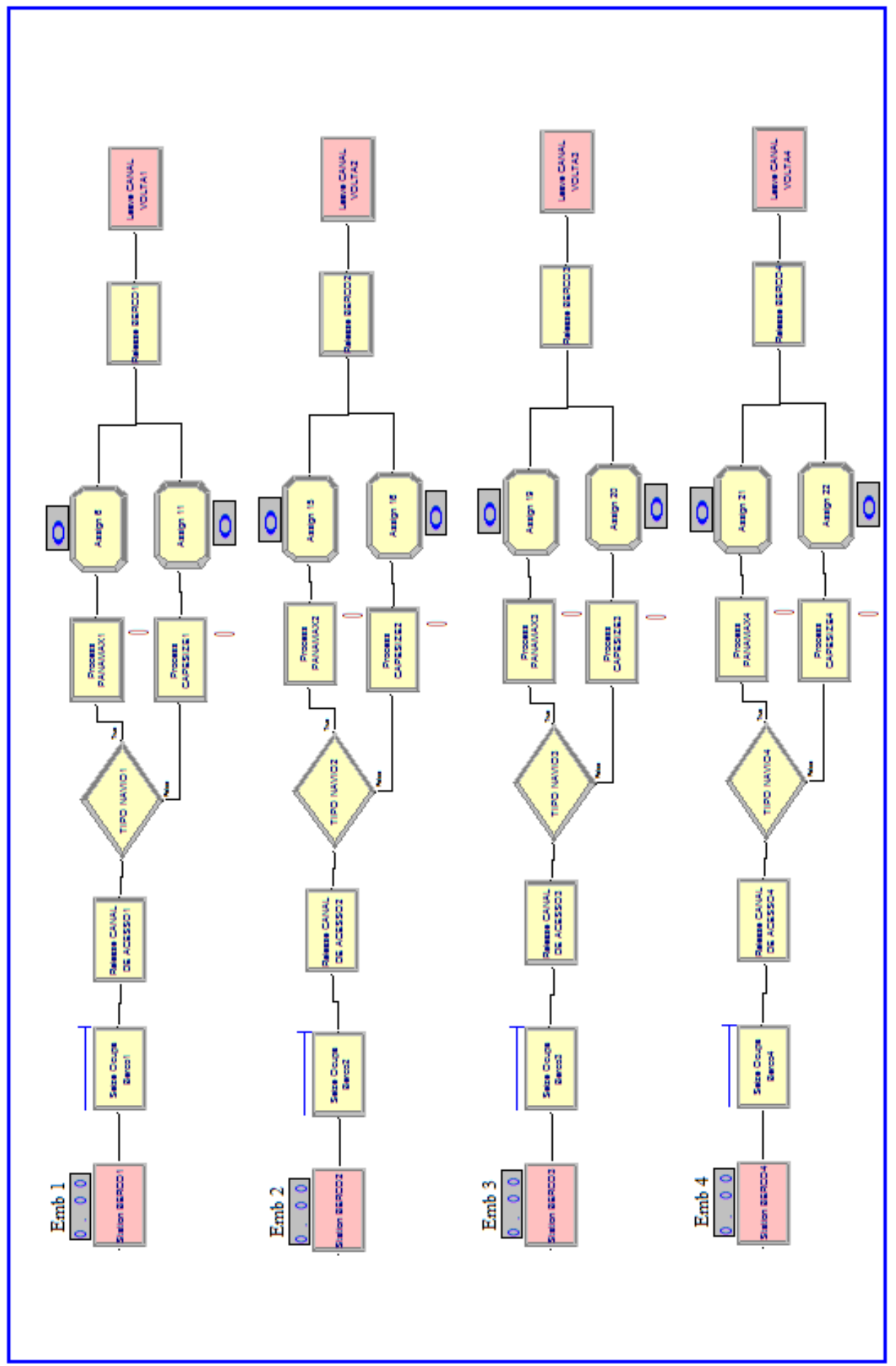

Figura 20 - Berços de atracação dos navios e processo de carregamento (1A). 
- Cenário 1B:

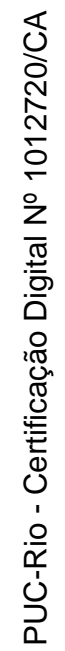

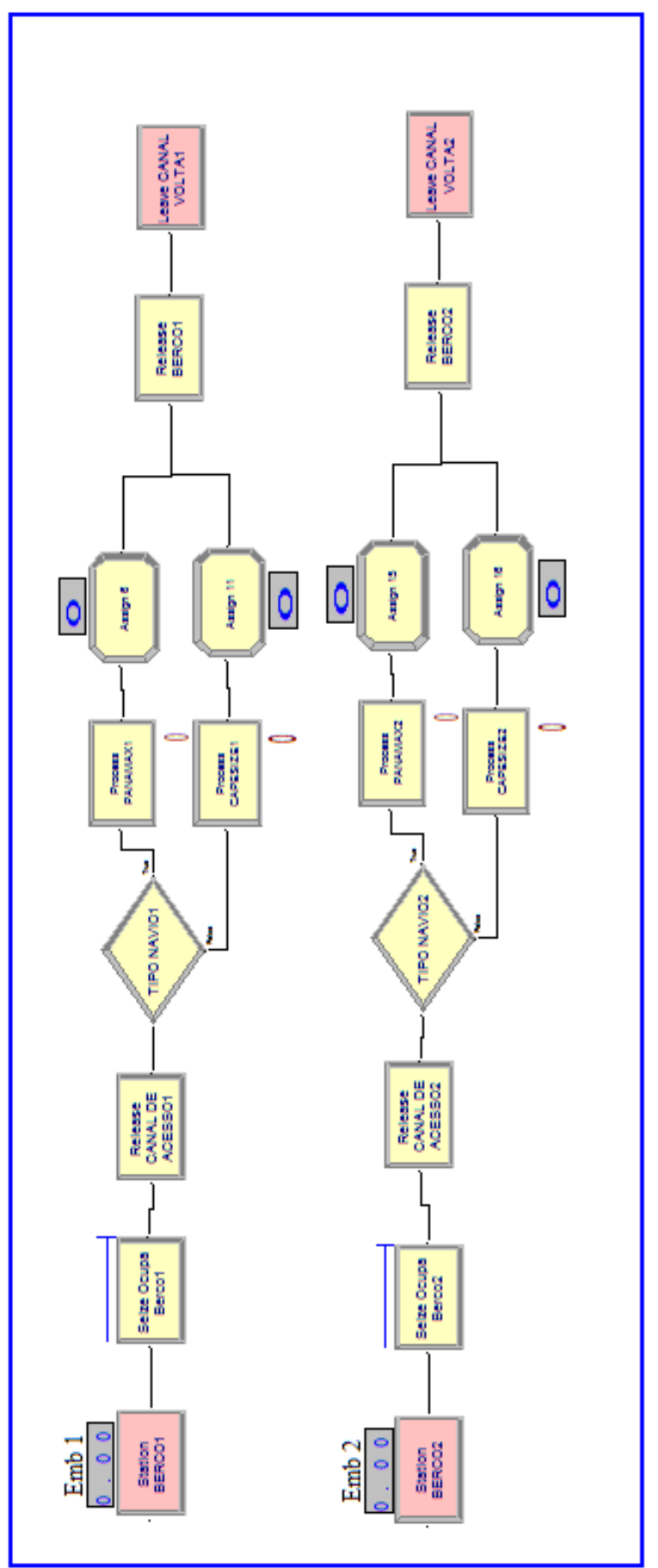

Figura 21 - Berços de atracação dos navios e processo de carregamento (1B) - parte 1. 
- Cenário 1B (continuação):

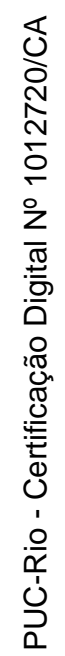

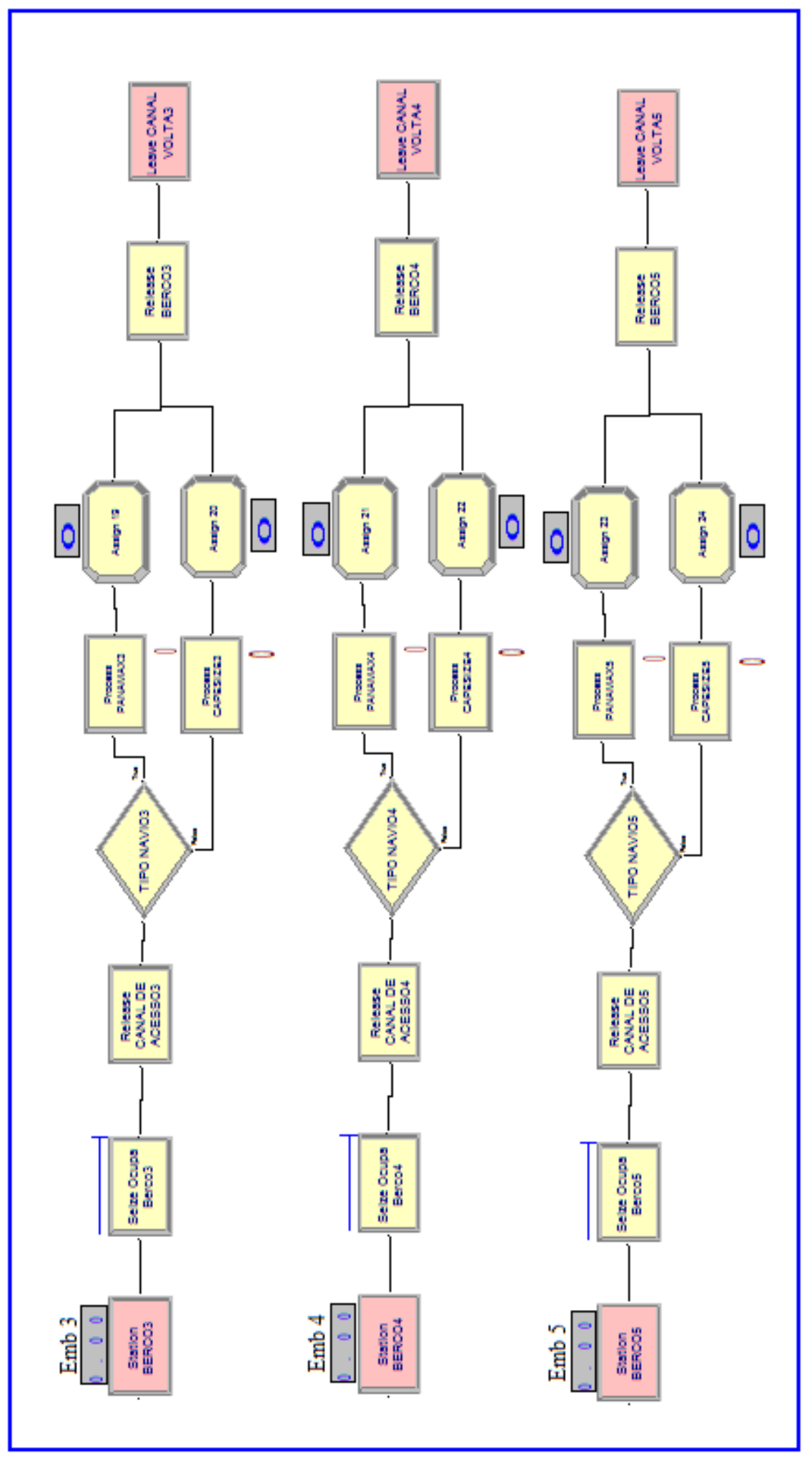

Figura 22 - Berços de atracação dos navios e processo de carregamento (1B) - parte 2. 